\title{
From drinking fountains to promenades. Water as artistic medium?
}

Antoni Remesar. Polis Research Centre- CRIT Research Group. Universitat de Barcelona

ORCID: 0000-0002-1145-6279- Scopus Author ID: 55323348400- Researcher ID: J-9745-2016

aremesar@ub.eduwww.ub.edu/escult

\section{ABSTRACT}

\section{From drinking fountains to promenades. Water as artistic medium?}

In From public art to post-muralism. Policies of urban decorum in Urban Regeneration (I) processes (Remesar 2019) when investigating the link of Public Art to urban Regeneration processes, we concluded that, possibly, the time of Public Art periclines and, for better or for worse, we enter a stage in which the socalled "urban art" reigns, specifically what we called post-muralism, a series of artistic practices that anchor their development in the culture and experiences of graffiti.

The objective of this second part is to analyse the role that water has in the city, from the perspective of its connection with the new types of urban spaces that will appear since the beginning of the modern era, and its role in relation to the statuary, public art and landscaping. The research deepens the processes of aestheticization of cities that occur before the emergence, as a dominant paradigm, of the paradigm of the modern movement.

To address this objective, we analyse how the fountains have gone from being mere artefacts to supply water to the city, to elements of urban composition and urban decorum. The article is divided into the following sections

[1] Water in the square where the ways of supplying water are reviewed;

[2] Opening spaces for [almost] everyone where we study the emergence of new public spaces and the role that water plays in them;

[3] Providing water in which the role that fountains play as an interface with users is reviewed;

[4] Serial fountains: a first step in the democratization of art, reviews the important role of cast iron fountains as diffusers of masterpieces of art hidden in museums;

[5] Beyond utility. Water in the urban landscape, reviews how the emergence of public spaces such as parks will cause the use of water in a new, more monumental format.

To this section follows [6] Finally, public space for all [or almost all], which reviews the role of the hygienist model in the creation of new public spaces and the value given to water, recovering water fronts (rivers, sea) and generating new public spaces such as "promenades", "costaneras" or "ma- 
lecones". This section implicitly argues that the development of these spaces is linked to the urban patriciate as a ruling class.

Finally [7] Water as an urban spectacle, addresses the new model of water use in public spaces that the interests of the new urban service companies associated with the urban patriciate will ensure that it is massive and spectacular, associated with electricity as a new urban service.

KEYWORDS: water; public space; sculpture; fountains; promenades; urban services

\section{RESUMEN}

\section{De las fuentes de boca a los paseos. ¿El agua como medio artístico?}

En Del arte público al post-muralismo. Políticas de decoro urbano en procesos de Regeneración Urbana (I) (Remesar 2019) al investigar la vinculación del Arte Público a los procesos de Regeneración urbana, concluíamos que, posiblemente, el tiempo del Arte Público ha periclitado y, por bien o por mal, entramos en una etapa en que reina el llamado "arte urbano", específicamente el que denominábamos post-muralismo, una serie de prácticas artísticas que anclan su desarrollo en la cultura y experiencias del grafiti.

El objetivo de esta segunda parte es analizar el papel que tiene el agua en la ciudad, desde la perspectiva de su vinculación con los nuevos tipos de espacios urbanos que irán apareciendo desde los inicios de la era moderna, y su papel en relación a la estatuaria, el arte público y el paisajismo. La investigación profundiza en los procesos de estetización de las ciudades que se dan antes de la irrupción, como paradigma dominante, del paradigma del movimiento moderno.

Para abordar este objetivo se analiza cómo las fuentes han pasado de ser meros artefactos para suministrar agua a la ciudad, a elementos de la composición urbana y el decoro urbano. El artículo se divide en los siguientes apartados

[1] Agua en la plaza en el que se revisan los modos y formas de abastecer de agua;

[2] Abriendo espacios para [casi] todos que estudia la aparición de los nuevos espacios públicos y el papel que en ellos cumple el agua;

[3] Suministrando agua en el que se revisa el papel que las fuentes cumplen como interface con los usuarios;

[4] Fuentes seriadas: un primer paso para la democratización del arte, revisa el importante papel de las fuentes de hierro fundido como difusoras de obras maestras del arte escondido en los museos;

[5] Más allá de la utilidad. El agua en el paisaje urbano, revisa cómo la emergencia de espacios públicos como los parques provocarán una utilización del agua en un nuevo formato más monumental.

A este apartado sigue [6] Finalmente, espacio público para todos [o casi todos], que revisa el papel del modelo higienista en la creación de nuevos espacios públicos y el valor que se le da al agua, recuperando los frentes de agua (ríos, mar) y generando nuevos espacios públicos como los "paseos marítimos", las "costaneras" o los "malecones". En este apartado se sostiene, implícitamente, que el desarrollo de estos espacios está vinculado al patriciado urbano como clase dirigente.

Finalmente [7] El agua como espectáculo urbano, aborda el nuevo modelo de uso del agua en espacios públicos que los intereses de las nuevas compañías de servicios urbanos asociadas al patriciado urbano procurarán que sea masivo y espectacular, asociado a la electricidad como nuevo servicio urbano.

PALABRAS CLAVE: agua; espacio público; escultura; fuentes; paseos marítimos; servicios urbanos 


\section{Des les fonts per beure als passeigs. L'aigua com a mitjà artístic?}

En De l'art públic al post-muralisme. Polítiques de decòrum urbà en processos de Regeneració Urbana (I) (Remesar 2019) a l'investigar la vinculació de l'Art Públic als processos de Regeneració urbana, concloíem que, possiblement, el temps de l'Art Públic ha periclitat i, per bé o per mal, entrem en una etapa en què regna l'anomenat "art urbà", específicament el que anomenàvem post-muralisme, una sèrie de pràctiques artístiques que ancoren el seu desenvolupament en la cultura i experiències del grafit.

L'objectiu d'aquesta segona part és analitzar el paper que té l'aigua a la ciutat, des de la perspectiva de la seva vinculació amb els nous tipus d'espais urbans que aniran apareixent des dels inicis de l'era moderna, i el seu paper en relació a l'estatuària, l'art públic i el paisatgisme. La investigació aprofundeix en els processos d'estetització de les ciutats que es donen abans de la irrupció, com a paradigma dominant, del paradigma de el moviment modern.

Per abordar aquest objectiu s'analitza com les fonts han passat de ser mers artefactes per subministrar aigua a la ciutat, a elements de la composició urbana i el decòrum urbà. L'article es divideix en els següents apartats

[1] Aigua a la plaça en què es revisen les maneres i formes d'abastir d'aigua;

[2] Obrint espais per a [gairebé] tothom que estudia l'aparició dels nous espais públics i el paper que en ells compleix l'aigua;

[3] Subministrar aigua en què es revisa el paper que les fonts compleixen com interfície amb els usuaris;

[4] Fonts seriades: un primer pas per a la democratització de l'art, revisa l'important paper de les fonts de ferro colat com difusores d'obres mestres de l'art amagat als museus;

[5] Més enllà de la utilitat. L'aigua en el paisatge urbà, revisa com l'emergència d'espais públics com els parcs provocaran una utilització de l'aigua en un nou format més monumental.

A aquest apartat segueix [6] Finalment, espai públic per a tothom [o gairebé tothom], que revisa el paper de el model higienista en la creació de nous espais públics i el valor que se li dona a l'aigua, recuperant els fronts d'aigua (rius, mar) i generant nous espais públics com els "passejos marítims", les "costaneres" o els "dics". En aquest apartat es sosté, implícitament, que el desenvolupament d'aquests espais està vinculat al patriciat urbà com a classe dirigent.

Finalment [7] L'aigua com a espectacle urbà, aborda el nou model d'ús de l'aigua en espais públics que els interessos de les noves companyies de serveis urbans associades al patriciat urbà de procurar que sigui massiu i espectacular, associat a l'electricitat com a nou servei urbà .

PARAULES CLAU: aigua; espai públic; escultura; fonts; passejos marítims; serveis urbans 


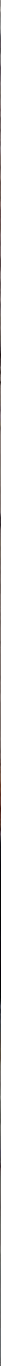

Fontana Maggiore.. Nicola (father) and Giovanni (son) Pisano. 1275-1278. Perugia Piazza Grande (now Piazza IV Novembre)

\section{Water in the square}

Water supply has always been one of the most important concerns of any local government.

Cities have always had a need for water, and guaranteeing it has led to the design of a supply and distribution infrastructure (wells, pipes, aqueducts, sources). Water fulfils an urban function.

It is from the fourteenth and fifteenth centuries when some of the Italian cities of the Renaissance will introduce new values in the urban composition and in the evolution of its landscape. On the one hand, the central squares of the city are organized around a style, so that a more or less unitary treatment of the facades and pavements take a leading role in the general composition of the site, giving rise to the "art urbain" (Choay 1998; Remesar, 2016)

On the other hand, they provide a deep aesthetic function to the fountains, which go from being purely functional and architectural elements to elements with a dual character, continuing with their instrumental function of water supply, but acquiring an important symbolic value through the introduction of big sculptural compositions. Consider the different fountains that punctuate the landscape of Renaissance cities, such as the Gaia Fountain in the Campo del Siena square, by Jacopo della Quercia (1419), which in the 19th century would suffer a vandalism in the name of 

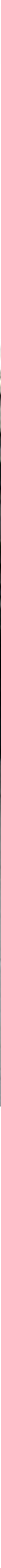

\section{Barcelona}

Font de Santa Anna, 1356

Ceramics by Josep Aragay, 1918

Font de Sant Just, 1367

Font de Santa Maria or Font dels Senyors. 1403

bourgeois morals; the fountains of the project of the Campidoglio square in Rome by Michelangelo (1535); the Fountain of the Innocents in Paris, by Jean Goujon (1549); that of Neptune in the Plaza de la Signoria in Florence, the work of Ammannanti (1560-1575) and companion of Michelangelo's David, or the spectacular Bernini fountains in Rome, already in the 17th century.

The composition of representative sets will be increasingly important, combining the design of the surroundings, especially through the stylistic unit facades, with the design of the horizontal support, i.e. the ground, introducing the practice of paving ornamental in certain areas of the city (Esparza, 2017). Finally, some cities reserve the central space of the square for the installation of the statue of the lord of the city or the state, as in the case of the equestrian statue of the condotiero Gattamelata, by Donatello, in Padua, work done between 1446 and 1450, which prefigures the type of royal square present in Europe between the seventeenth and nineteenth centuries. 
The fountain produced only a small flow of water because of the poor water supply system of Paris. Under Napoleon Bonaparte, a new aqueduct from the River Ourcq supplied water,so that the fountain gushed water, threatening the sculptural decoration. The smaller bas-reliefs at the base of the fountain were removed in 1810 and placed in the Musée du Louvre in 1824. In 1858, the fountain was again moved, to its present location on a modest pedestal in the middle of the square; and six basins of pouring water, one above the other, were added on each façade.

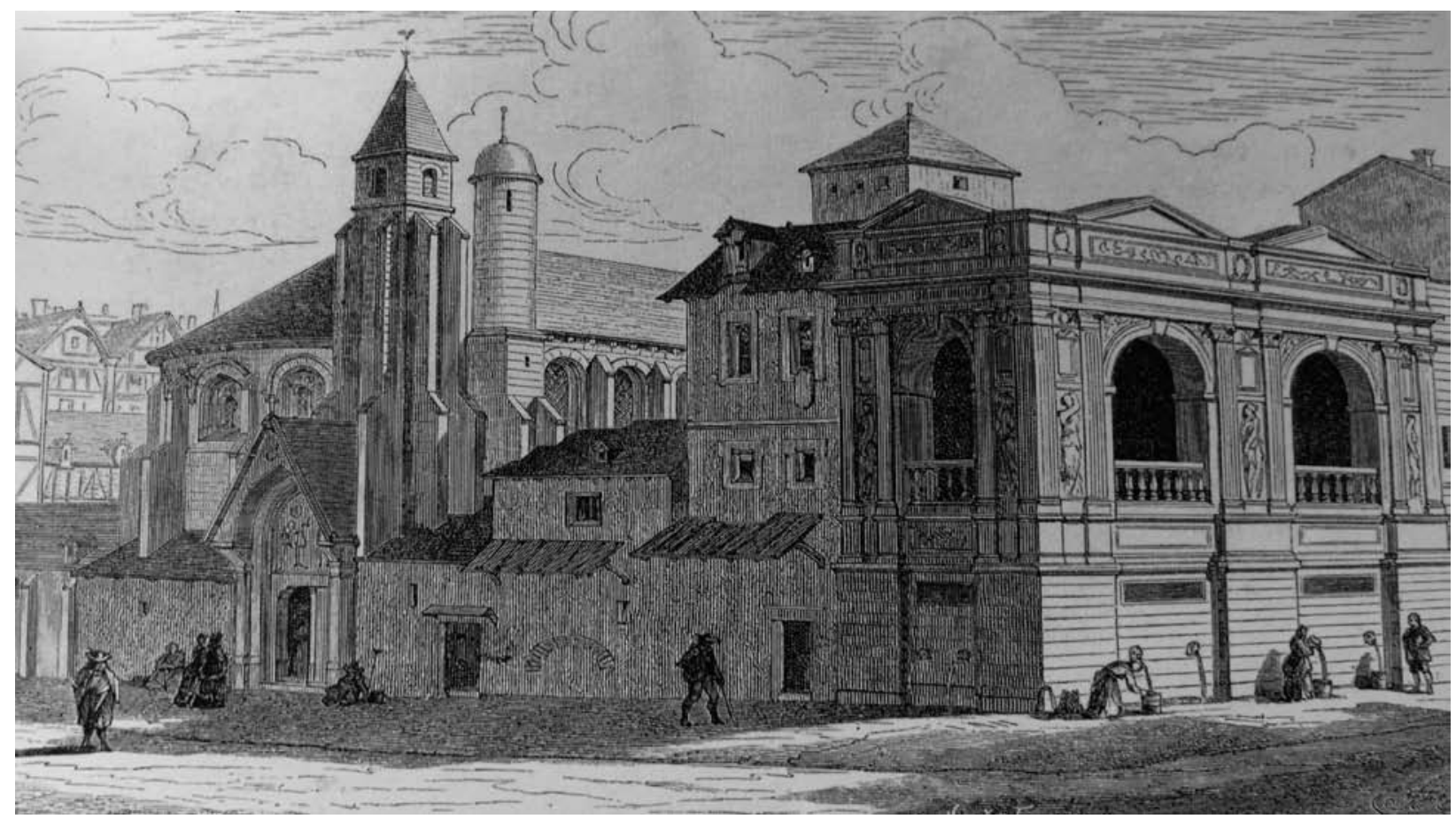

Etienne Huyot or Jules Huyot. 19th century recreation of the Fountaine des Innocents in its original site Bibliotheque des arts decoratifs, Paris (source wikipedia.fr)

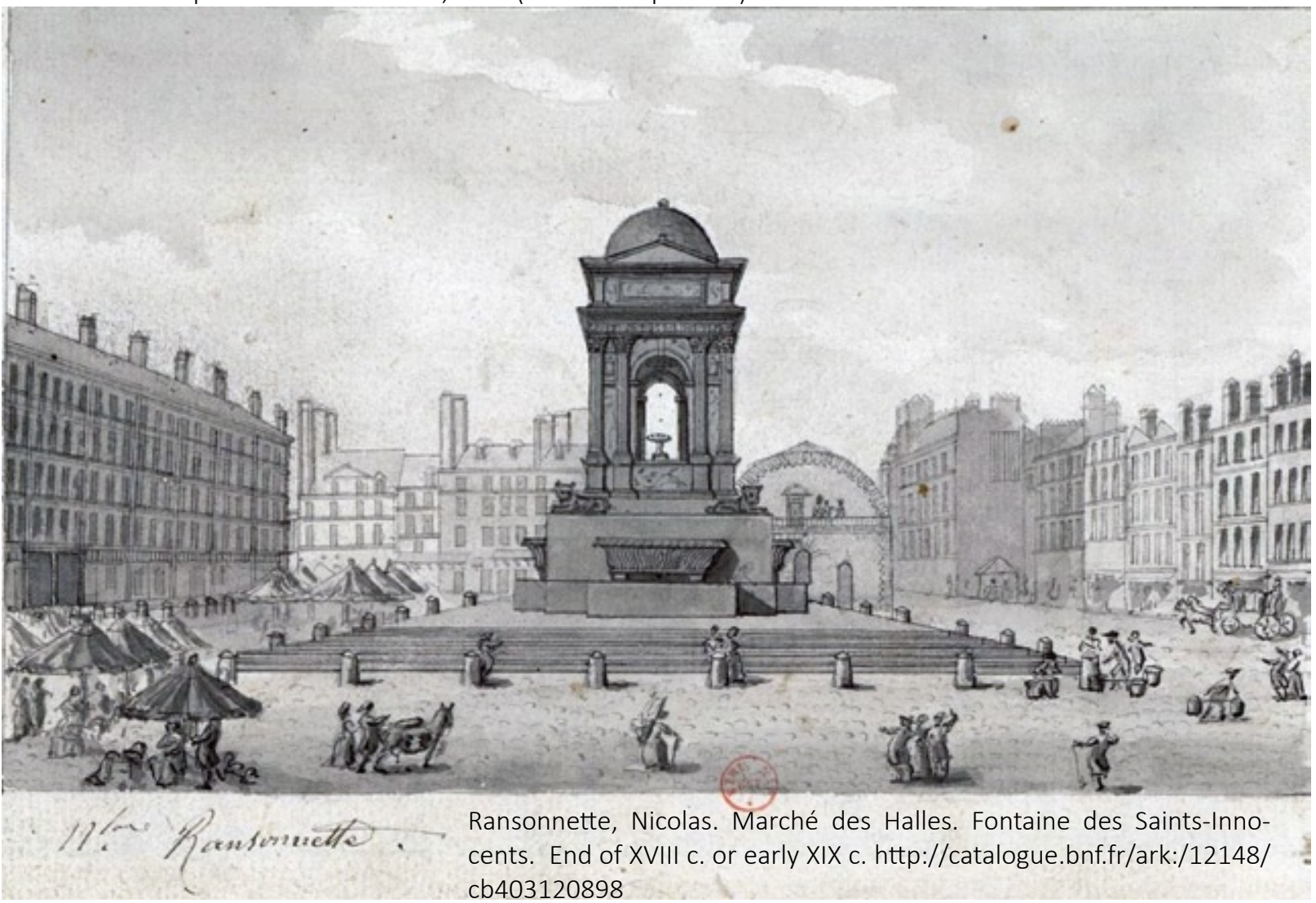




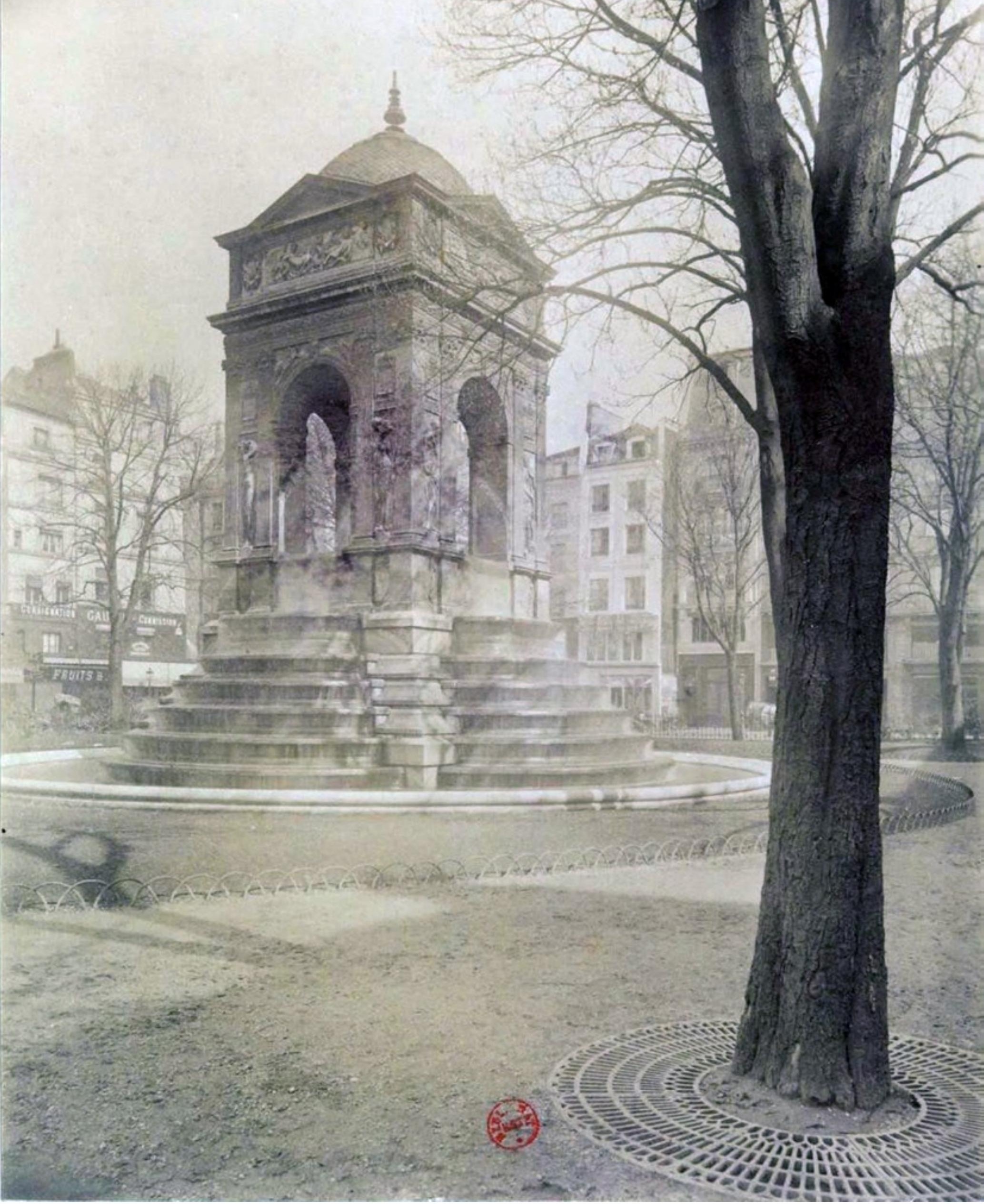

Atget, Eugène. Fontaine des Innocents. 1900. http://catalogue.bnf.fr/ark:/12148/cb40275634f 


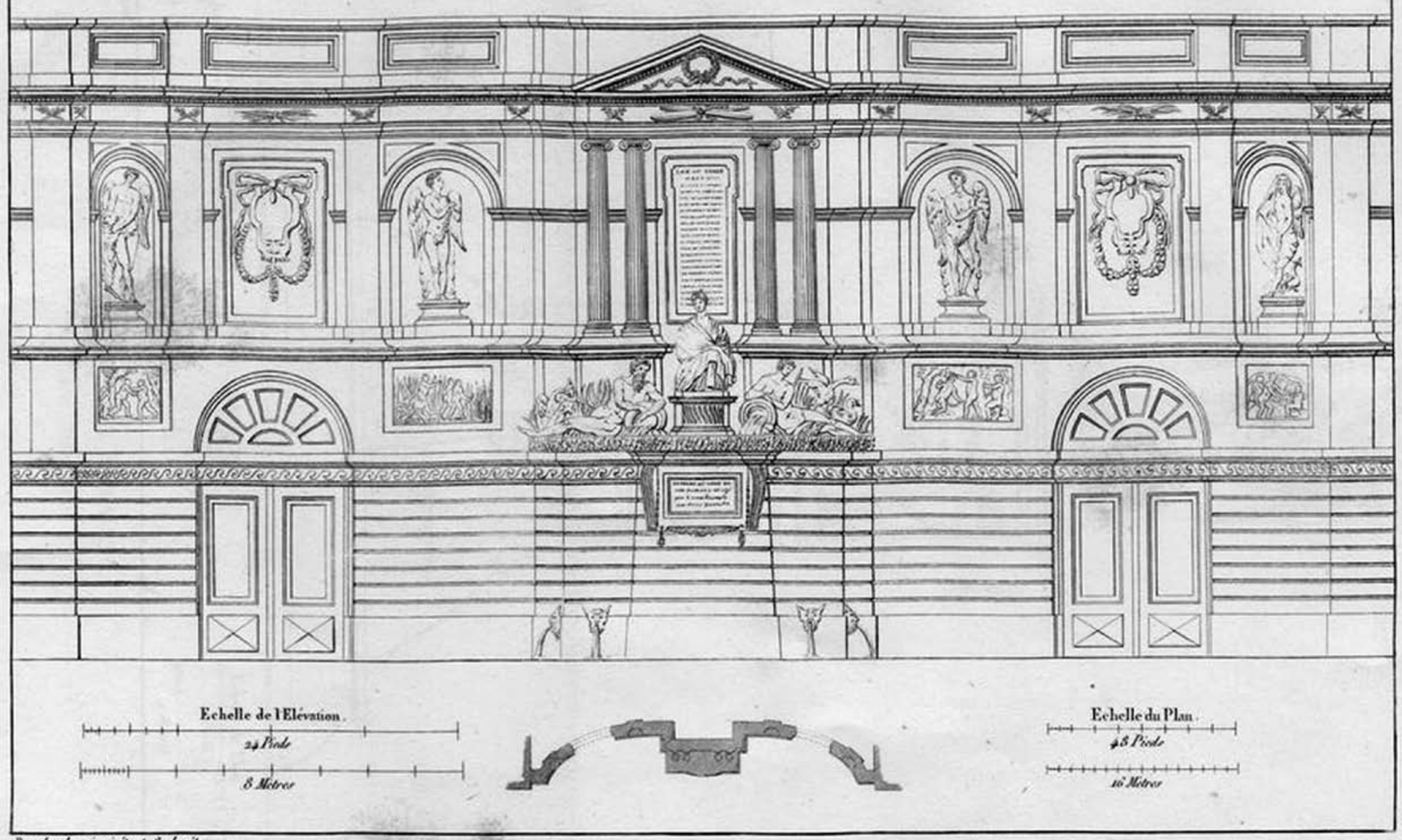

FONTAINE DE GRENELLE.

From Fontaines de Paris by Moisy, Normand et al. 1855

\section{Fontaine des Quatre-Saisons or Fontaine Grenelle. Paris}

While the fountain des Innocents initially has a purpose of celebration, Grenelle's fountain is clearly a "vassalage monument" (Remesar 2011). This type of monument implies the symbolic manifestation of the guardianship, dominion or protection of the Lord,- secular or religious- in order to confirm and strengthen the bond of dependence and fidelity of the vassal. We must distinguish these monuments from those commemorative since the "vassalage monuments" are ordered and executed by the Lord while still alive. They do not have the mission of remembering, but the praise and glorification of the Lord. In the fountain of the Grenelle is clear in the following inscription in gold letters engraved on black marble

Whereas Louis $X V$, the object of the love of his people and excellent father, the support of public tranquility, after having recovered, without the flow of blood, the frontiers of the Kingdom of France, and since peace has been happily restored between the Germans and the Russians and the Subjects of the Ottoman Empire, ruling in a manner both glorious and peaceful; the Prevot des marchands and the town counselors have devoted this fountain to the service of the citizens and to the beautification of the city in the course of the year 1739

The Fontaine des Quatre-Saisons was the largest and most ornate of the several fountains built in Paris in the 18th century to provide drinking water to the city's residents. Between 1715 and 1724, the Conseil d'Etat of King Louis XV began discussing the idea of a new fountain in the Faubourg Saint-Germain area, which was rapidly growing. They first discussed placing in other sites 


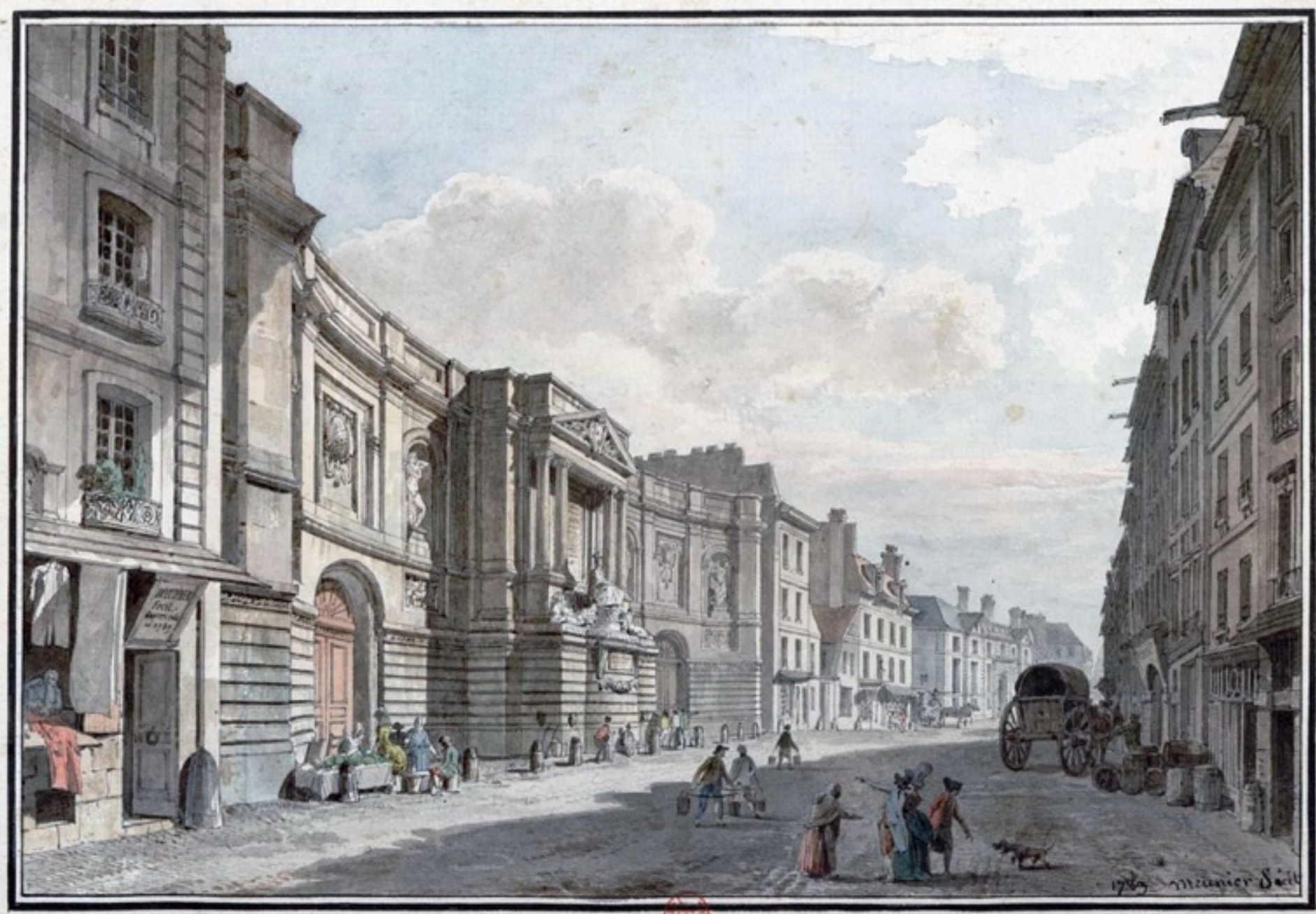

Fontaine de Bouchardon, rue de Grenelle by Meunier, Antoine 1789. http://catalogue.bnf.fr/ark:/12148/cb403120956

and finally decided present site on rue de Grenelle, on a plot owned by the convent of Récollettes. The project was approved by the Prevot des Marchands, who shared authority for all fountains and water projects in Paris, and was given in 1739 to the Royal sculptor, Edme Bouchardon, for completion. Bouchardon worked for seven years on the project and displayed the plaster models for the central group of sculptures at the Salon du Louvre in 1740, and the bas-reliefs in 1741. The fountain was not completely finished until 1745.

While the fountain had an abundance of statuary, it did not produce very much water. Only one aqueduct brought water to the Left Bank at the time, the aqueduct de Arcueil, which brought water to the left bank from Rungis. The water flowed to the Fontaine Saint-Michel, then by a secondary pipe to the Fontaine des Quatre-Saisons. The water was stored in the upper part of the fountain, and flowed by gravity down to two spouts in form of lion's heads, from which water flowed continually. The water was collected in vessels by local residents, or by water porters (porteurs d'eau) who carried the water to other parts of the quarter and sold it to the inhabitants.

After the fountain was built, there were many calls for it to be moved, included one by Volataire?

7.- The monument has been criticized for its excessive size compared to the street where it stood. On January 9, 1739, Voltaire wrote to the Count of Caylus: The Parisians should do more to embellish their city, to destroy the monuments of Gothic barbarism, and particularly these ridiculous village fountains which disfigure our city. I have no doubt that Bouchardon will make this fountain a beautiful piece of architecture; but what is a fountain leaning against a wall, in a street, and half hidden by a house? What is a fountain with only two taps, where the water carriers will fill their buckets? This is not the way to build the fountains with which Rome is embellished. We find it hard to get out of the mean and rude taste. Fountains must be erected in public places, and beautiful monuments must be seen from all doors. There is not a single public square in the vast Faubourg Saint-Germain: it makes your heart bleed. Paris is like the statue of Nebuchadnezzar, partly gold and partly mud. (Sarmant 1999). 


\section{Opening spaces to [almost] everybody}

In the period of the Counter-Reformation, in the context of the important reforms of urban centres, initiated by Sixtus $V$ in Rome under the Nolli plan and based on the principles of Alberti (Alberti, 1452), a profound renovation is carried out of European medieval cities. The streets widen. Perspectives are created, punctuated with obelisks and statues; the longitudinal cross-section is ordered by the systematic straight layout, the heights of houses are ordered and a relatively strict but figurative control of the landscape composition of the facades is initiated (Laugier, 1755; Sabaté, 1999).

In this period a series of experiments will take place in the gardens, few in the centre of the old city, the most, far from the walls, in rural space. Both the English landscape gardens and the French formal gardens were established in the sphere of the private space of the dominant classes, of the aristocracy, and in them water plays a fundamental role, both in the form of large ponds and in the form of spectacular jet water or sculptural fountains, such as in Versailles, in which Le Nôtre demonstrates his genius.

The big gardens of the 16th, 17th and 18th centuries were private walks, and only a small number of privileged people could enter them [...]. There were no public properties, since it was contrary to the ideas of that time; Maybe that's why it seemed dangerous or shocking. It has been found that good and beautiful things are even better when their use is accessible to all ... The public promenades that have recently been created in Europe are almost all reminiscent of those in Paris. (Alphand y Ernouff, 1875).

Although it should be noted that, against the restrictions of the privative, we can find some initial examples of public malls, in Seville, Alameda de Hércules (1574). The Alameda de Hércules, is considered the oldest intra-wall mall in Europe. In 1574 the grounds where the alameda was going to be built were drained, which were often flooded with the water that accumulated there from the frequent overflows of the Guadalquivir river, the remnants of the public fountains and the waste sewage (Albardonedo 2002). It was adorned with statues and fountains, and with rows of trees. At the southern end, two third-century Roman columns were laid. These columns come from a building at Marbles street (where there are still three columns) and its transfer was commissioned to the founder master Bartholomew Morel. Two sculptures made by Diego de Pesquera, one of Hercules (mythical founder of the city) and the other of Julio Caesar (restorer of Hispalis) were placed on them. The first was a copy of Hercules Farnesio. In addition, these sculptures represented the two monarchs of the new house reigning in Spain. Thus, Hercules represents the emperor Charles I and Julio Caesar represents his son Philip II. Thus, the first civil monument in Seville was completed, and on December 28, 1574 the new Mall was completed, although its renovation was always necessary over the years. 


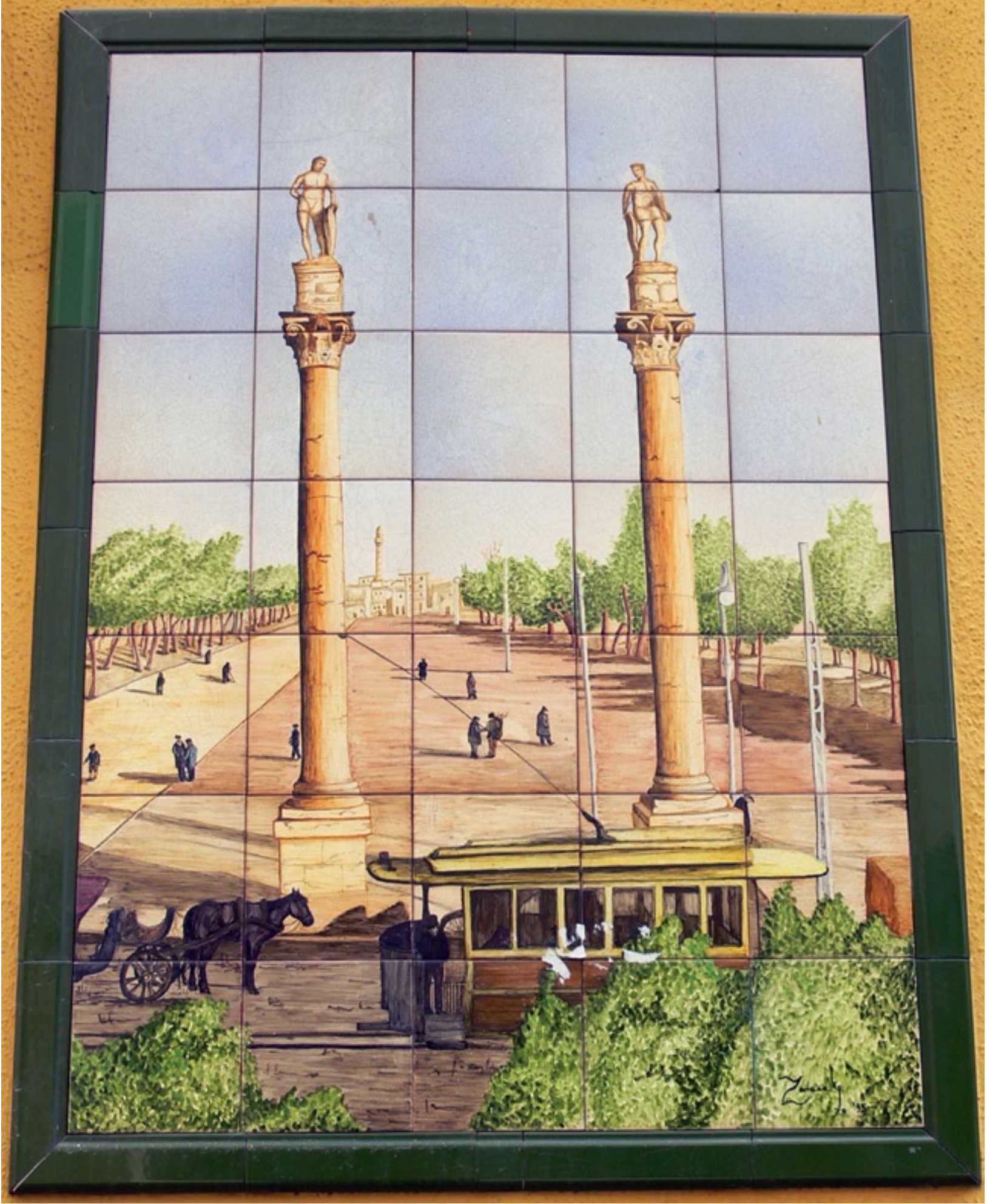

The Sevillian mall is the model for cities like, México, Central Mall, 1592; Lima, Los Descalzos Mall, 1611 and Acho's Mall, 1773 (Hamann 2011); San Francisco's Mall in Puebla, circa 1621, today transformed in a commercial mall (Hernández 2009); La Havana, Paula's Mall, 1777 (Garcia \& Ríos, Marien, 2013), Barcelona (Sant Joan Mall, 1796-1802).

Although, in the layout of the Hispanic malls we must recognize the influence of other model, that of the Paseo del Prado in Madrid, with its different modifications from its incipient beginnings in 1570 until its crystallization as "Salón del Prado" in 1763.

If the Sevillian and Madrid models set the standard for the construction of malls in the cities of Hispanic empire, long afterward, the "public passeio" in Lisbon will be the model for the Portuguese- 


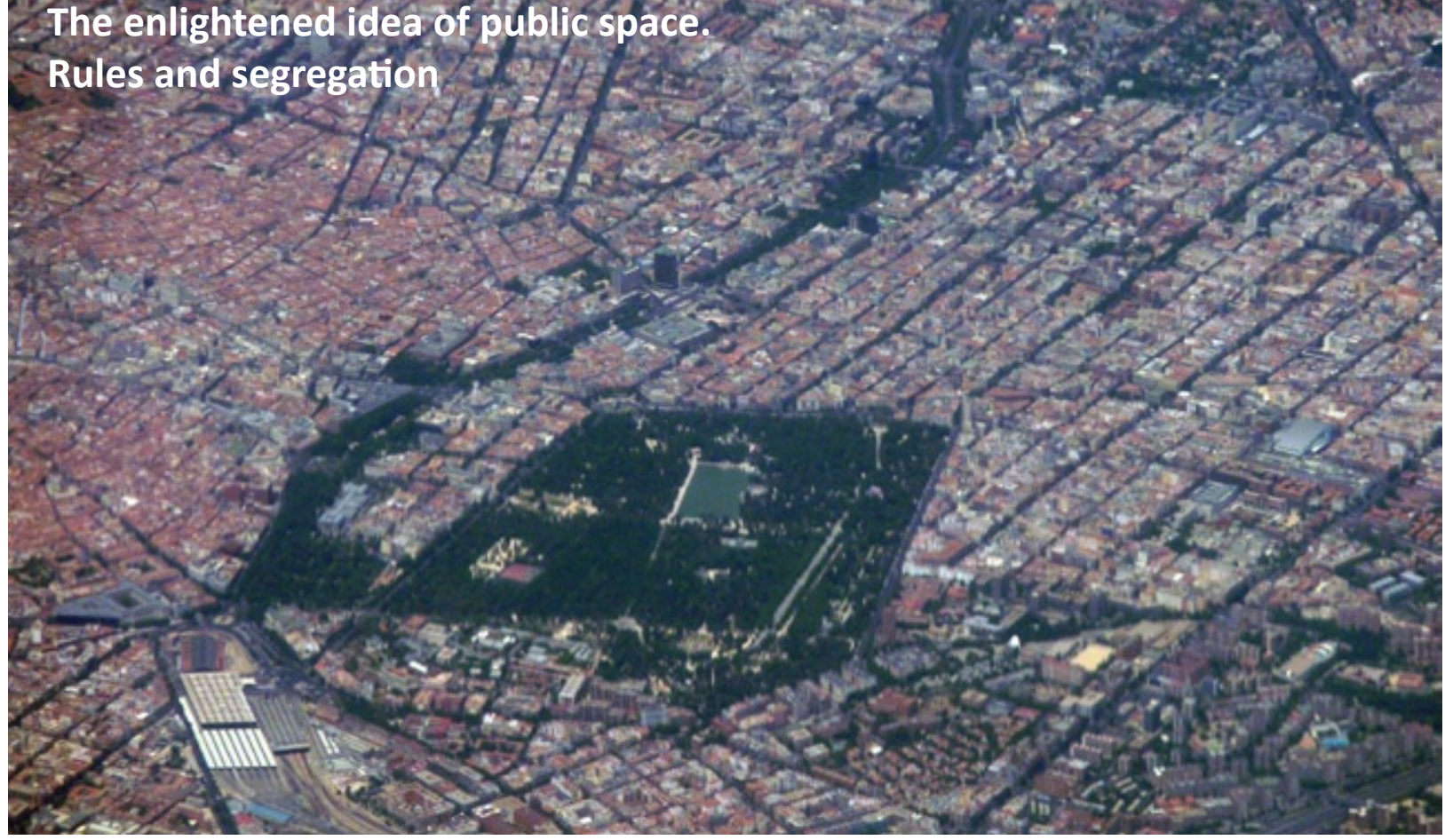

Madrid. Parque del Retiro- Prado- Castellana axis

speaking cities (Henriques da Silva, 1997; Pessoa, 1997). This mall, designed by Reinaldo Manuel dos Santos and redesigned in the 19th century by Malaquias Ferreira and Domingos Parente da Silva, was opened by the Marquis of Pombal in 1764, and was another work in the process of rebuilding Lisbon after the 1755 earthquake.

Today, the "passeio" has been subsumed on the magnificent Avenida da Liberdade. In 1873, according to the project of Resano Garcia and the architect Parente da Silva, the idea of building the mall was presented to the City Council. On August 24, 1879, solemn start of the work, by Rosa Araújo, mayor of the municipality. The first section opens in 1882 and the whole avenue in 1886. Avenida da Liberdade, runs along a rectangular platform (1500 m by $90 \mathrm{~m}$ ), delimited at its ends by the Marqués de Pombal Square and the Restauradores Square.

Both the Paseo de Prado, as the current Avenida da Liberdade, start or end their path in a large park, respectively the Retiro in Madrid (Moral Ruiz, 2013) and Parque Eduardo VII in Lisbon.

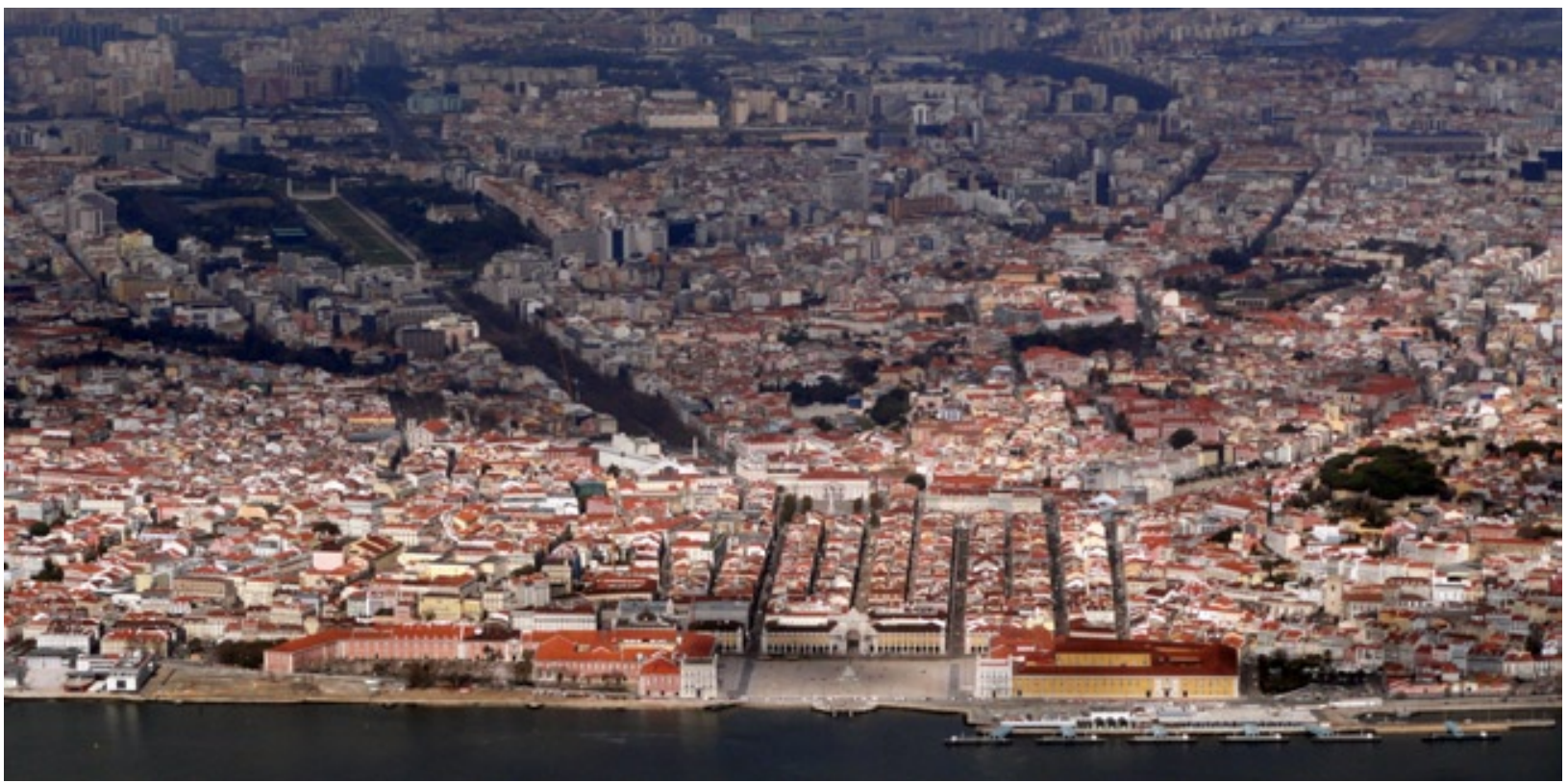

Lisboa. Baixa- Rossio- Restauradores- Liberdade- Parque Eduardo VII axis 


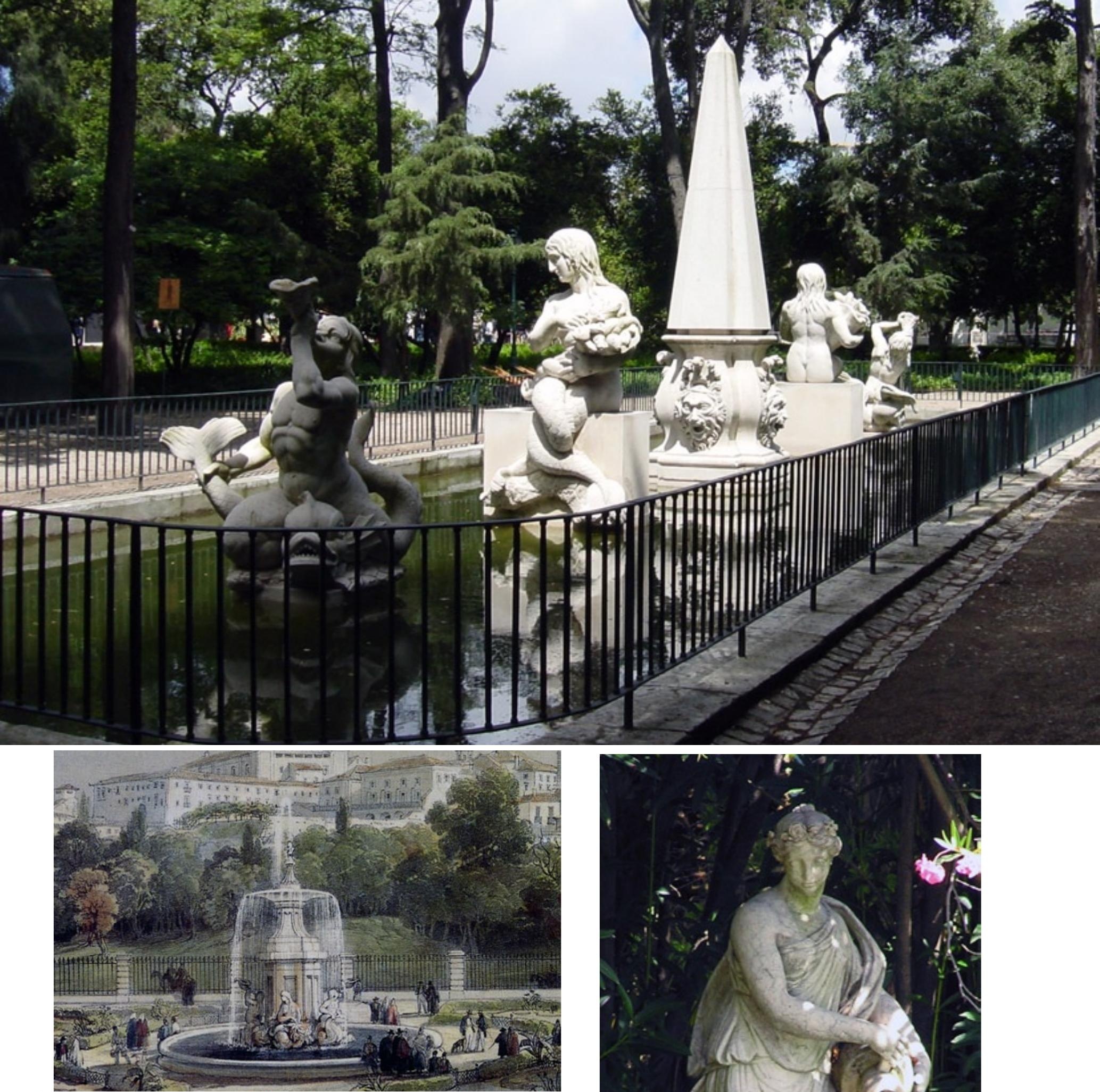

The sculptures of the old "Public Passeio" in Lisbon today converge in the Pimenta Palace, headquarters of the City Museum (group of sculptures of the fountain) and in the "Cold Greenhouse".

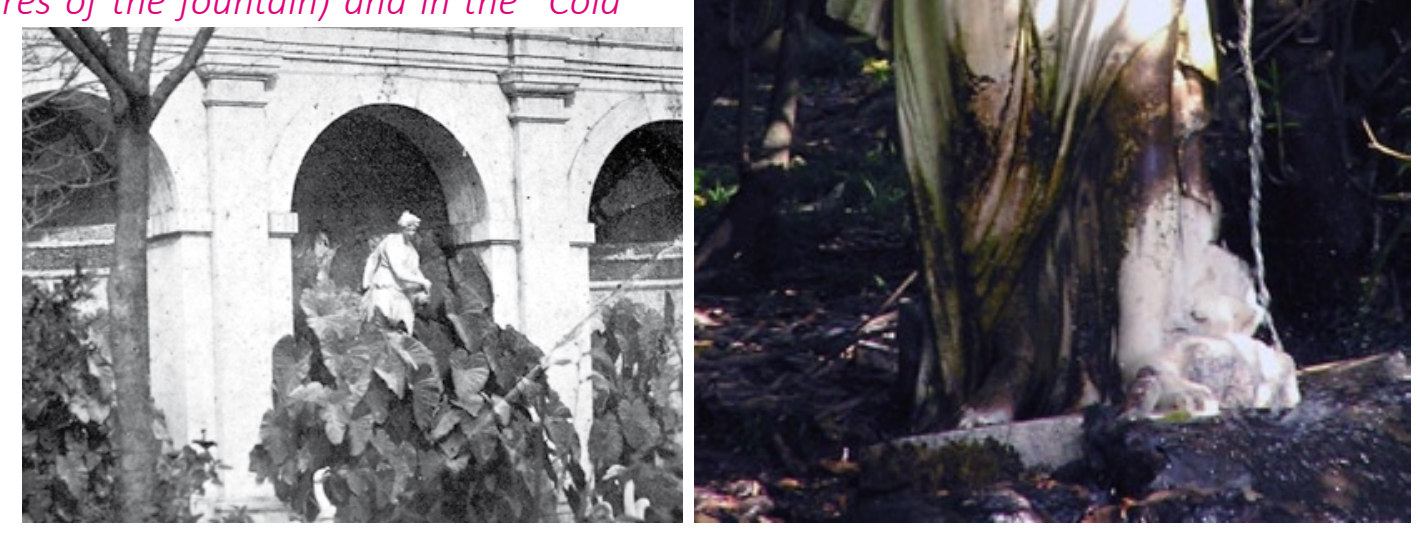




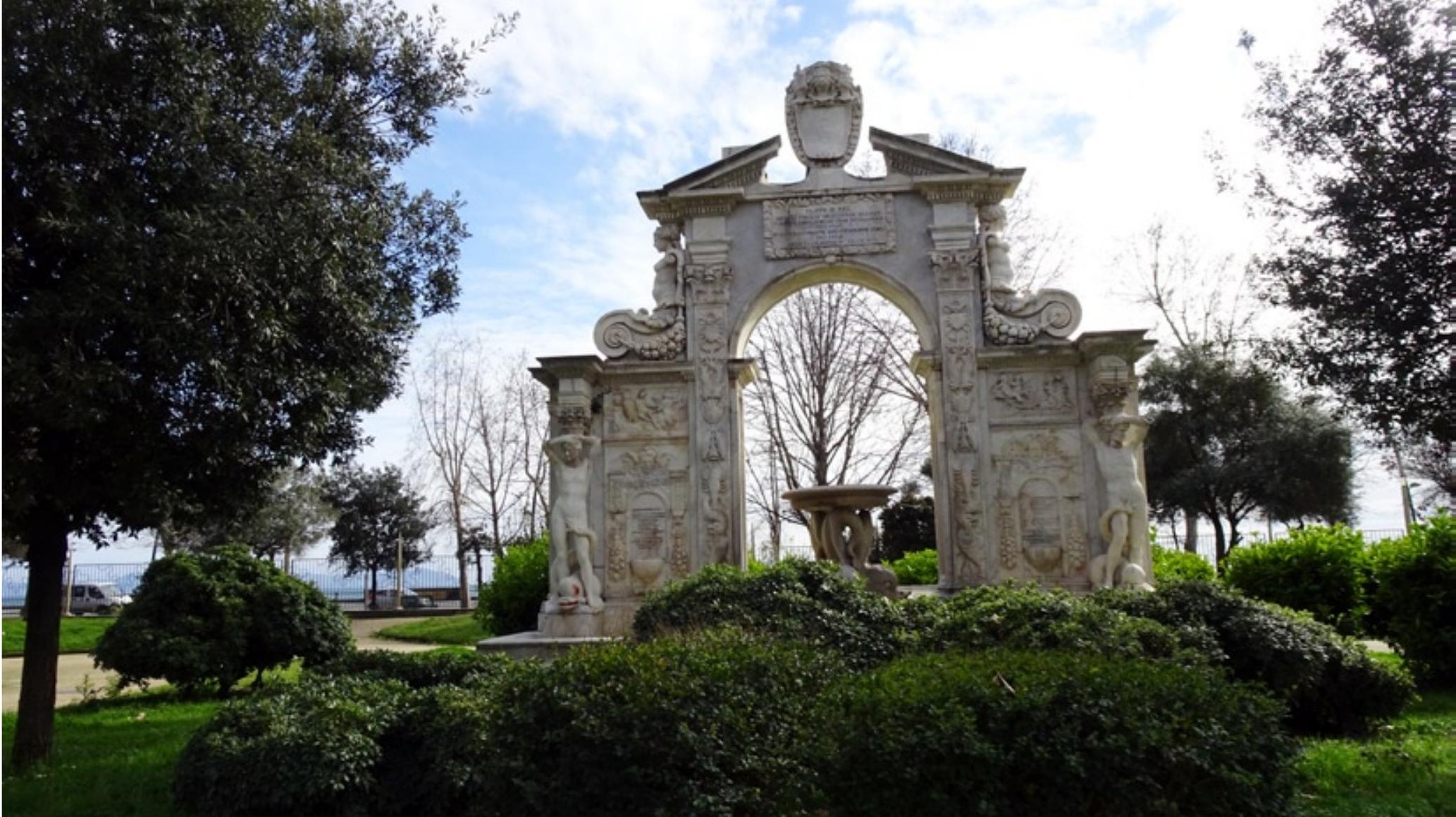

Fontana di Santa Lucia, Fountain designed by the engineer Alessandro Ciminiello and built in 1606 by Michelangelo Naccherino and Tommaso Montani with the collaboration of Girolamo D'Auria and Vitale Finelli at the request of the Viceroy Giovanni Alfonso Pimentel d'Errera, Duke of Benavente. It was originally located on the seafront of the village of Santa Llúcia, from which the fountain takes the name.

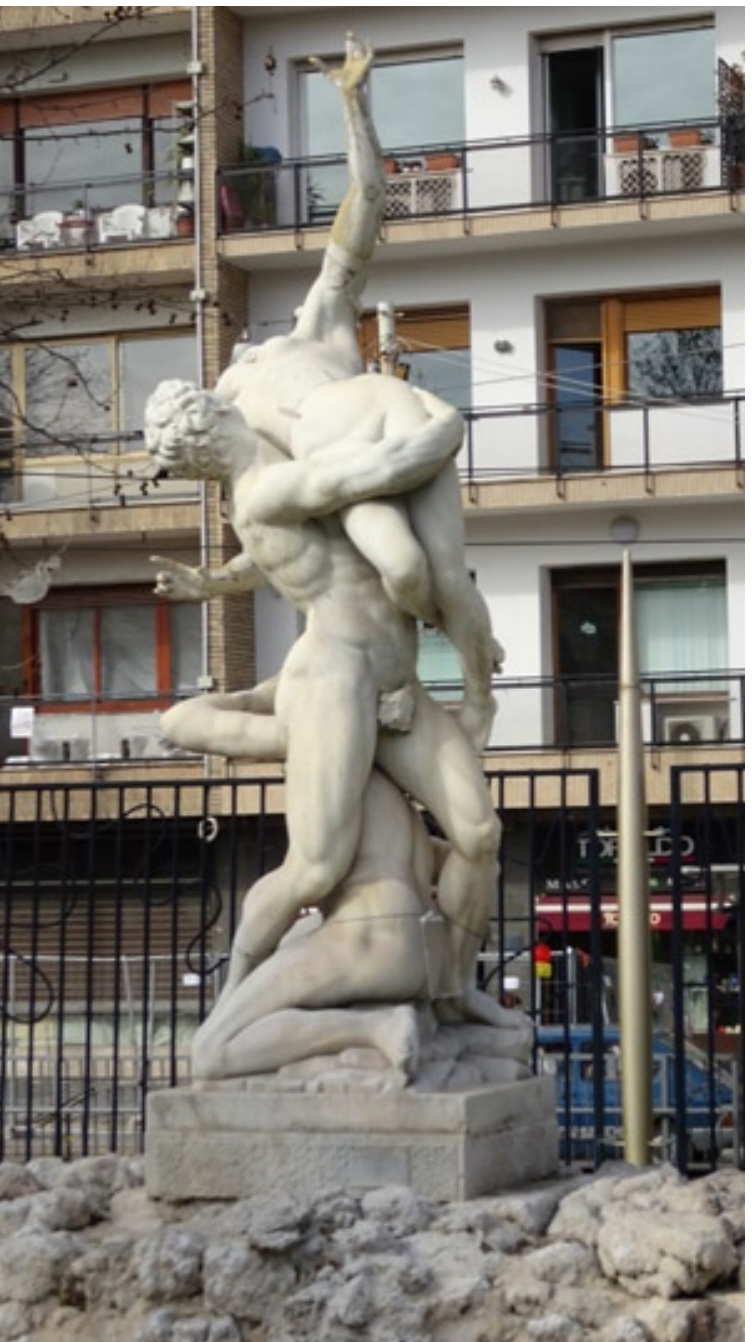

In Italy we highlight two interventions interventions. In Naples, the communal villa ( Ugramin s/f) started in 1672 and in Pádova, a special case, the square-mall, Prato della Vale, 1775.

The first nucleus of the villa comunale goes back to 1672, when the Spanish Viceroy Duke of Medinaceli, planted. along the Riviera di Chiaia. a double row of trees embellished with thirteen fountains, providing a first idea of a promenade from the Chiaia Gate to the Neapolitan Crypt. Between 1778 and 1780 the area of the beach along the Riviera was transformed into a true promenade, an urban garden much in vogue at this time, by the will of King Ferdinand IV of Naples and by the work of the architect Carlo Vanvitelli - son of the most well-known Luigi- in line with the Salon del Prado (Madrid), raised by the father of the Neapolitan monarch, Carlos III of Spain. Vanvitelli was assisted by botanist Felice Abbate, a royal gardener.

Fontana del Ratto delle Sabine. . The sculptural group (a copy of Giambologna's original) was executed by the sculptor Genoese Tommaso Solari in the middle of the 18th century for the royal palace of Caserta and moved to the villa in the first half of the 19th century to continue the program that provided for other embellishments of the monumental complex. 
Water as an expression of enlightened power.

Places for ruling classes \& now for tourism
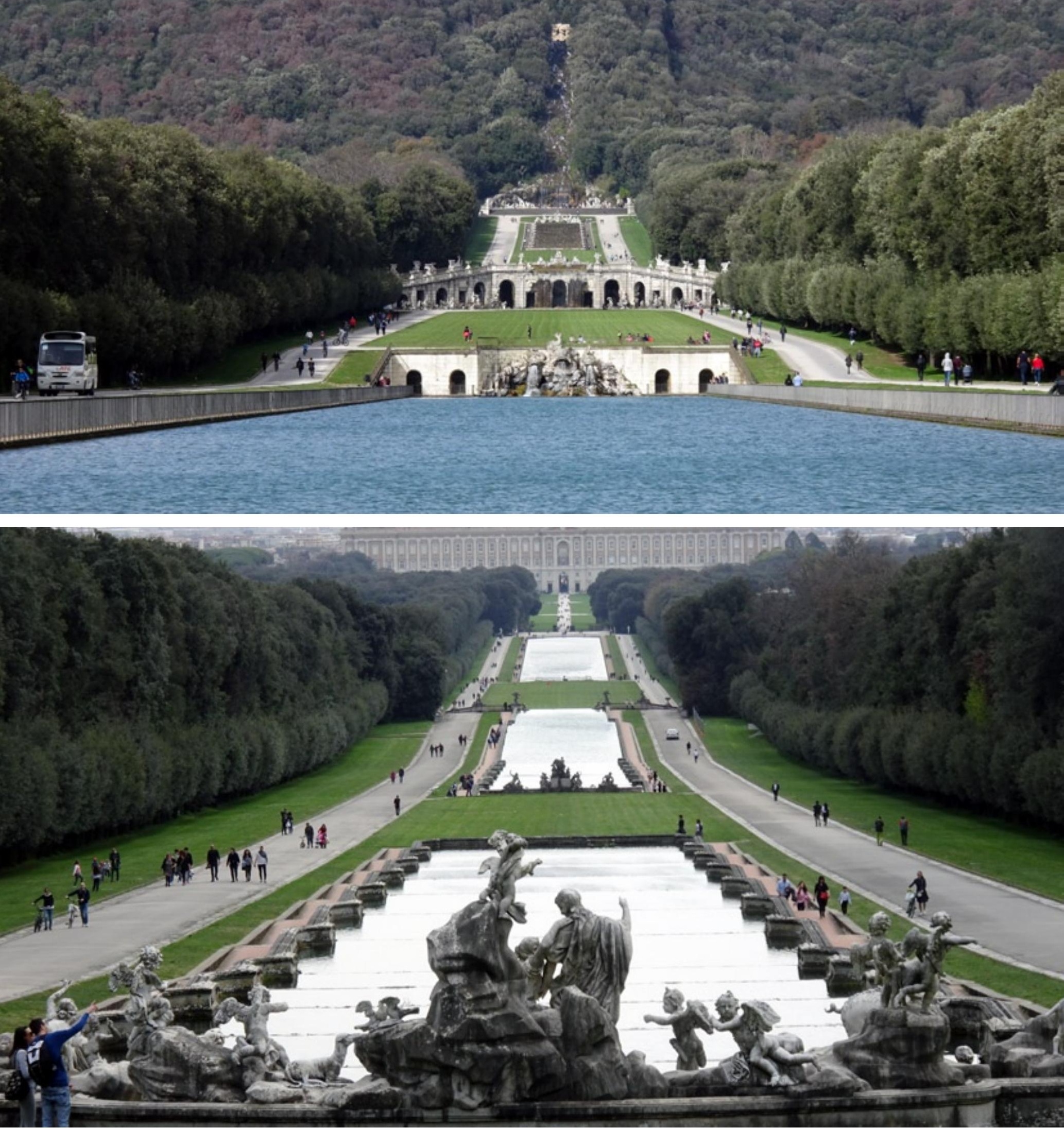

Caserta. Near Naples.

Gardens of the Royal Palace, large pools, waterfalls, jet water features, sculpture.. The ambitious project of King Charles VII of Naples (Carlos III of Hispania) was not limited to the building of a palace, but to create a new city that had all the urban advances of the time and were the most advanced capital in all of Europe. The architect that designed the palace and its gardens was Luigi Vanvitelli. The works began in 1753 


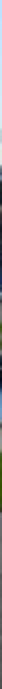

Prato della Valle in Padova, more than a mall, is a huge square, built on a marshy land and with an area of $90.494 \mathrm{~m}^{2}$. The Prato della Valle contains an island intended for walks, and ornamented with statues. Today, there are 78 statues (40 along the outer ring and 38 along the inside), but according to the original design they should have been 84. Prato della Valle today's aspect, Prato della Valle today's aspect, results from the destruction of six statues depicting Venetian Dogos, which were overthrown by the Napoleonic army in 1797. Strict regulations (published by Prato's presidency on February 10, 1776) set the rules for creating statues: no living person could be portrayed, saints could not be portrayed (church altars were reserved for them) and all the portrayed characters must have had a connection to the city. In most cases, they are university professors, artists, leaders or former city governors. The characters represented are Andrea Memmo (who owes the idea of Prato), Torcuato Tasso, Savonarola, Andrea Mantegna, Ludovico Ariosto, Petrarca or Antonio Canova among others. The only statue made by Antonio Canova is that of Giovanni Poleni. The statues were central to the transformation of the Prato not only visually but also economically. In fact, they were paid by citizens or individual groups with amounts ranging from 135 to 150 coins and which served both the cost of the statue and a contribution to the general work of the Prato. The amount could also be paid in two or three years. 

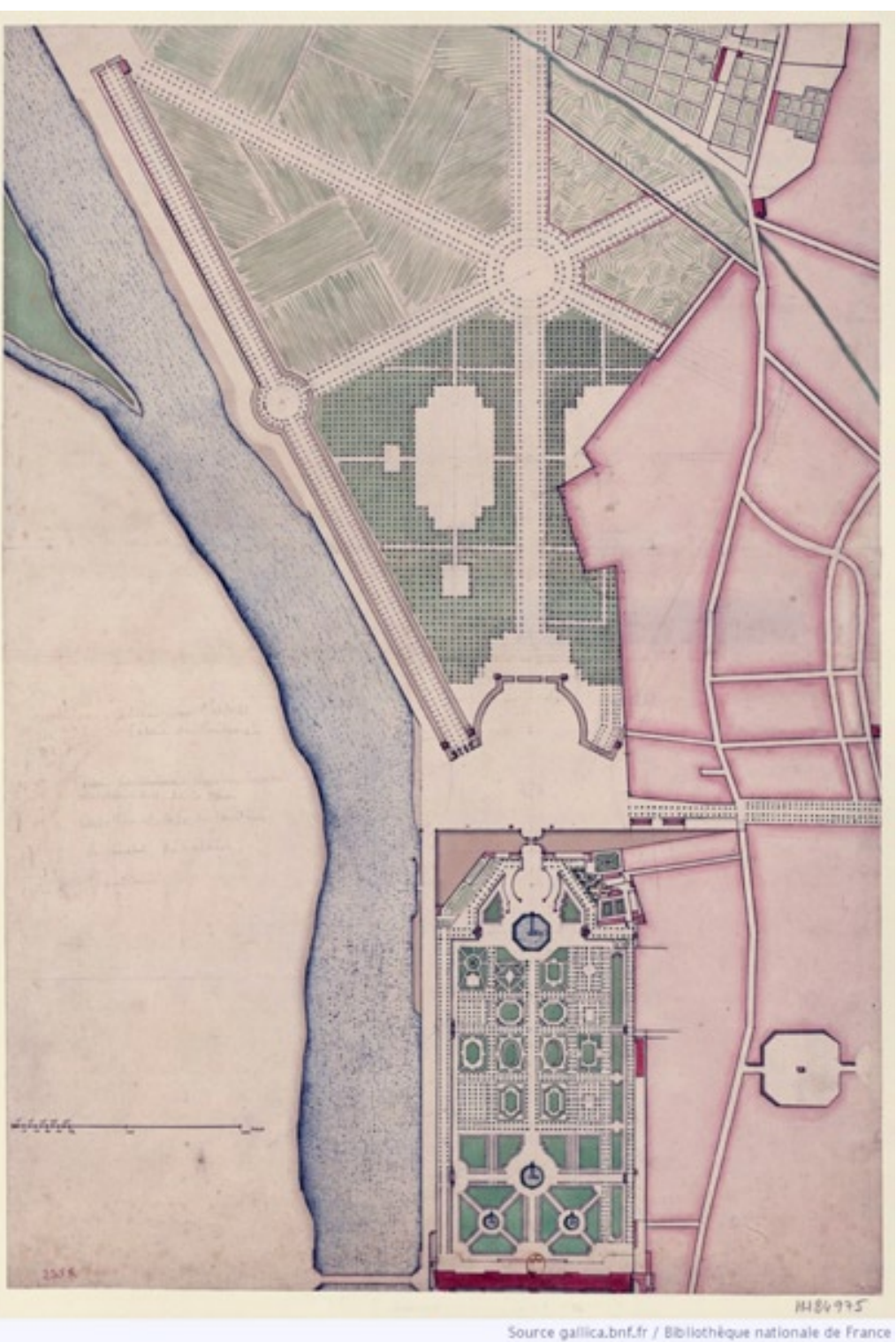

Plans généraux des Thuileries et des Champs-Elysées [plan de situation des Tuileries et des Champs-Elysées.1730 Source: gaIlica.fr, ark:/12148/btv1b53046294s

In France we highlight two interventions, one in Paris and one in Nancy.

\section{Paris, the system Tuilleries - Place de la Con- corde-Champs-Élysées.}

The Champs-Élysées were laid out in 1667 by André Le Nôtre ${ }^{7}$ as an extension of the Tuileries Garden (1564), that he had rebuilt in his formal style in 1664. Le Nôtre planned a wide promenade between the palace and the modern Rond Point, lined with two rows of elm trees on either side, and flowerbeds in the symmetrical style of the garden. The new boulevard was called the "Grand Cours", or "Grand Promenade". And took the name of Champs-Élysées in 1709. Next year, in 1710 the avenue was extended beyond the RondPoint as far as the modern Place d'Étoile. In 1765 the garden was remade in the Le Nôtre style by Abel François Poisson. Later on, the earl of Marigny, Director-General of the King's Buildings, extended the avenue again in 1774

as far as the Porte Maillot.

By the late 18th century, the Champs-Élysées had become a fashionable avenue. Following the French Revolution, two equestrian statues, made in 1745 by Nicolas and Guillaume Coustou, were transferred from the former royal palace at Marly and placed at the beginning of the boulevard and park. theatre, musical and circus performances. Several ornamental fountains were placed around the park.

In 1834 Jacques Ignace Hittorff was the architect commissioned by Louis-Philipe to redesign the square. Gabriel's design did not sufficiently enhance the connection axis between Quai d'Orsay and Rue Royale. Certainly, the new Concorde bridge (1787-1791) was not yet built which allowed us to think of an east-west connection and relegate the north-south connection. The redesign of the square partially replaces the octagonal shape with an oblong roundabout that facilitates

7.- It is necessary for a Le Nôtre to draw his plan, to do it with pleasure and ideas, to have in it, at the same time, order and fantasy, symmetry and variety... Let's put this idea into practice and use the design of our parks as plans for our cities. It is only about estimating the terrain and representing in it, in the same taste, roads that become streets and crossroads that will be our squares. We have cities whose streets are perfectly aligned, but as their design has made by people of little spirit, an insipid accuracy and a cold uniformity reigns in them .... they are cities in which everything refers to a unique figure, a great parallelogram crossed the length and breadth by lines at right angles .... it is not a trifle to design the plan of a city so that the magnificence of the total is subdivided into infinity of beautiful details all different (Laugier, Marc-Antoine, 1755, pp. 132-133) 
north-south traffic without damaging east-west movements. The defenestrated statue of Louis XV is replaced by an "axis world", the obelisk of Luxor that marks the centre of the new square. On the sides of the obelisk two monumental fountains that of "the seas" and that "the rivers." The two fountains celebrate river navigation (fountain on the north side towards the rue Royale) and maritime navigation (fountain on the south side towards the Seine). The river fountain is made up of seated figures representing the Rhine and the Rhône, products of the regions watered (grapes, wheat, fruit, flowers), statues of River Navigation, Agriculture and Industry.

The maritime fountain has six colossal figures representing the Ocean, the Mediterranean, fishing for fish, for corals and for pearls and shells. Swans mingle with three geniuses symbolizing Maritime Navigation, Commerce and Astronomy. For the statues adorning these fountains, the architect called on many artists: Jean-François-Théodore Gechter, Honoré-Jean-Aristide Husson, François Lanno, Nicolas Brion, Auguste-Hyacinthe Debay, Antoine Desboeufs, Jean-Jacques Feuchère, Antonin-Marie Moine, Jean-Jacques Elshoecht (aka Carle Elshoecht) and Louis-Parfait Merlieux.

They have the distinction of being cast iron, according to Hittorff's choice. They were to be carried out by the Parisian founder Calla, but it is the foundry of Tusey, in Vaucouleurs, which won the market. The cast iron was golden for its most symbolic parts.

The perimeter, basically pedestrian, uses small constructions of the previous project on which eight allegorical statues of the main cities of France are placed. The allegorical statues of eight French cities draw the outline of the octagon imagined by Gabriel. The one evoking Strasbourg is draped in black from 1871, date of the attachment of Alsace-Lorraine to Germany .

The square is equipped with street lamps, some monumental rostral street lamps ${ }^{8}$, many simpler ones. XV is replaced by an "axis world", the obelisk of Luxor that marks the centre of the new square. On the sides of the obelisk two monumental fountains, that of "the seas" and that "the rivers." The perimeter, basically pedestrian, uses small constructions of the previous project on which eight allegorical statues of the main cities of France are placed. The square is equipped with street lamps, some monumental rostral street lamps, many simpler ones. Rostral columns, $9.60 \mathrm{~m}$ high, carry the prows of ships suitable for gas lighting. They also evoke the emblem of the City of Paris. The same choice of foundry was made for the rostral columns also in cast iron and made at the same foundry in the Lorraine. The simplest lampposts are present, too, in the Champs-Élisées. Some of these lampposts can be found in Barcelona, specifically in the Plaza de Catalunya, since the 1929 Exhibition.

As seen in the images, Hittorff's work is huge announcing the new criteria necessary for the organization of public space for cities that face the challenge of the first industrial revolution. Hittorf starts a new paradigm in relation to the design of public spaces, a paradigm that will be deepen by Alphand and Davioud some years later when the Haussmann renewal of Paris will start (Alphand, 1867; Haddad 2017; Remesar, 2004a; 2007). This work is the beginning of a new industry linked to 

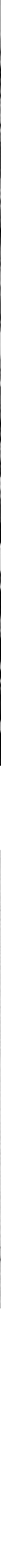

Jacques-Ange Gabriel. Plan de la place Louis XV (place de la Concorde) à Paris

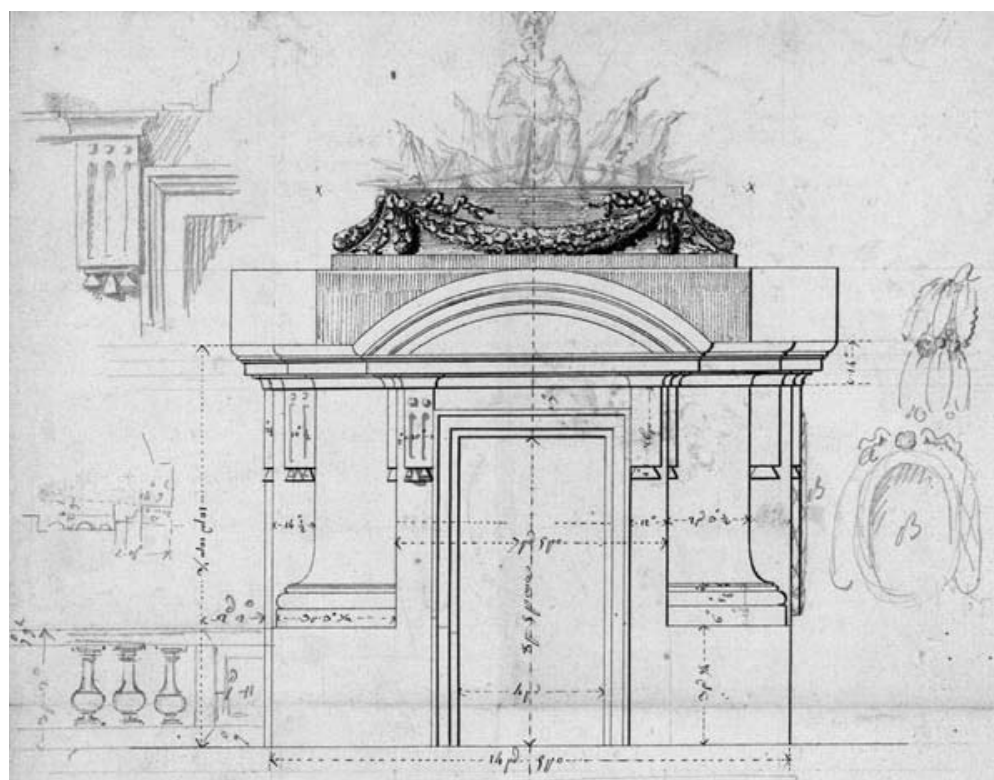

Plan des guerittes de la Place de Louis XV. Jacques-Ange Ga-

briel. http://catalogue.bnf.fr/ark:/12148/cb403125362

Statue equestre de Louis XV, // dont I'Inauguration a été faite à Paris le XX. Juin M. DCC. LXIII. // Dédié a Monsieur --- le marquis de Marigny. // Commandeur des ordres du Roi--- Directeur et Ordonnateur Général // de ses Batiments, Jardins, Arts, --- Académies et Manufactures Royales. // Par son très-humble--- et très-obéissant serviteur, Le Rouge : [estampe] / Bouchardon inventit ; Dessiné par Moreau le jeune.--- La Tête dessinée par Gautet et gravée par Catelin. 1767. Gallica.fr, ark:/12148/btv1b84096428 


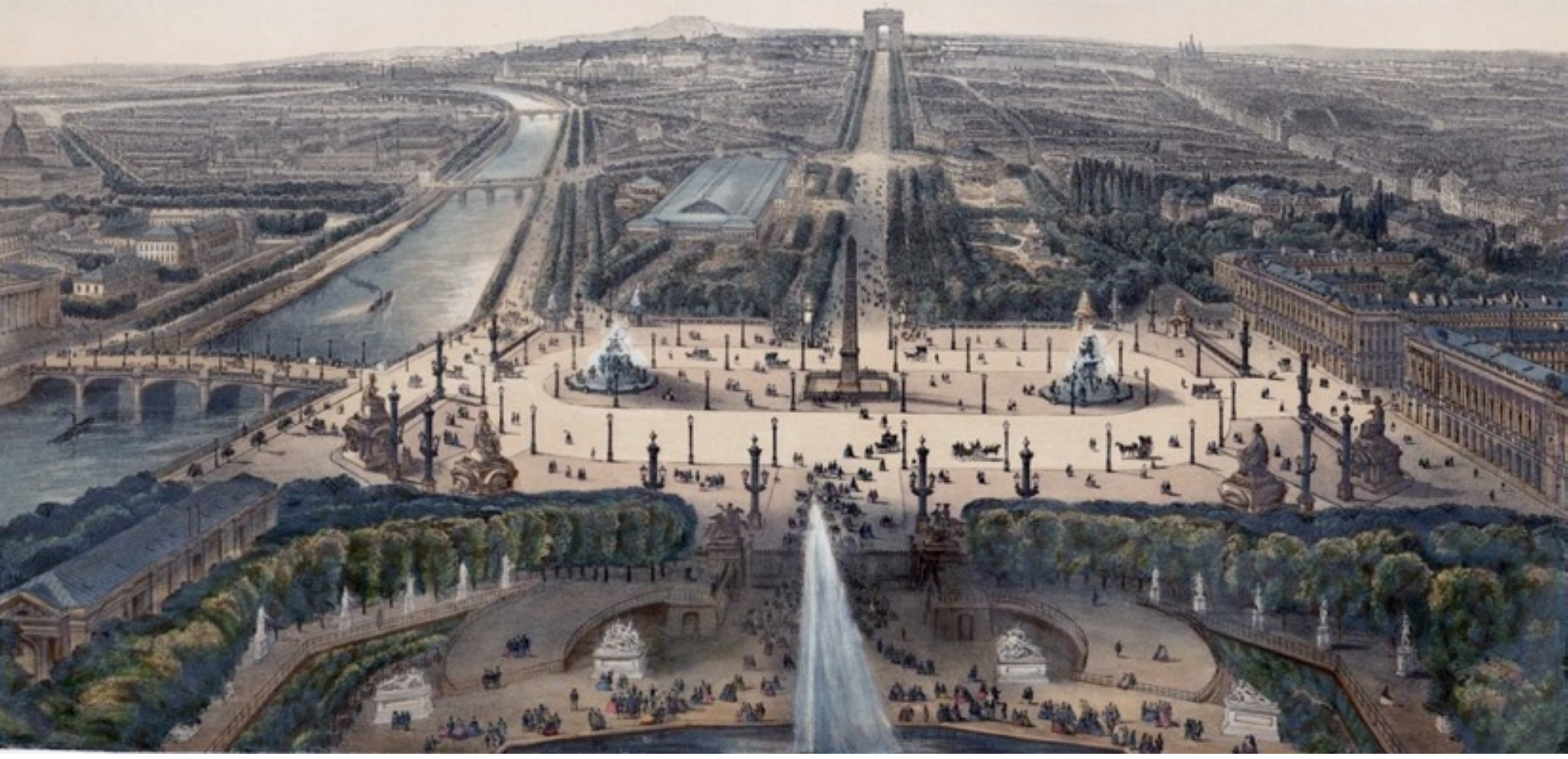

Paris, place de la Concorde Vue prise du Grand Bassin des Tuileries . Chapuy. Dessinateur du modèle. Muller, Th. Lithographe. c.1850. Gallica.fr. ark:/12148/btv1b53023720b

Fountain of the Seas
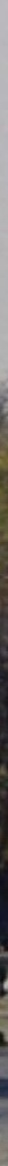


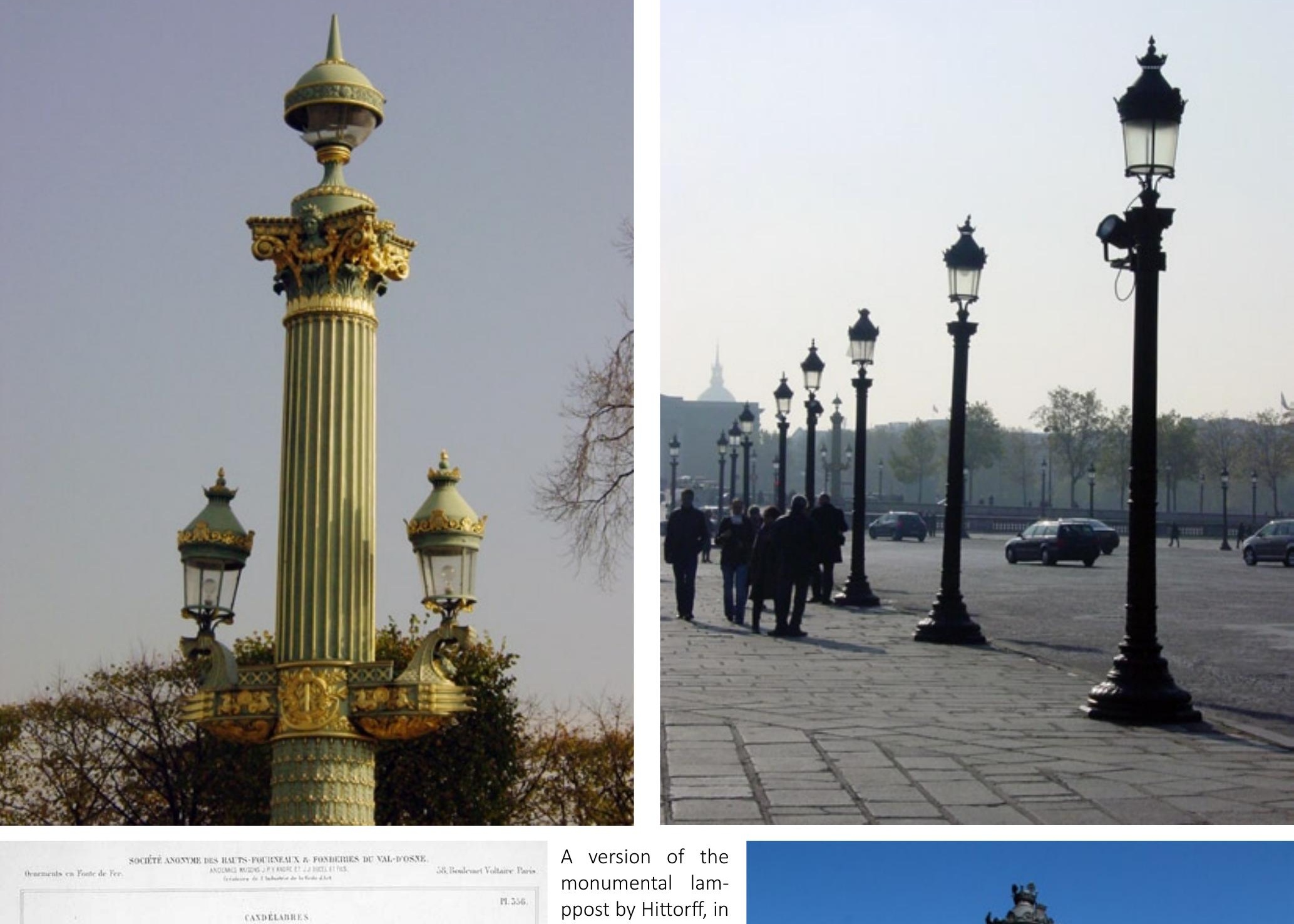

A version of the monumental lamppost by Hittorff, in a catalog of the Val

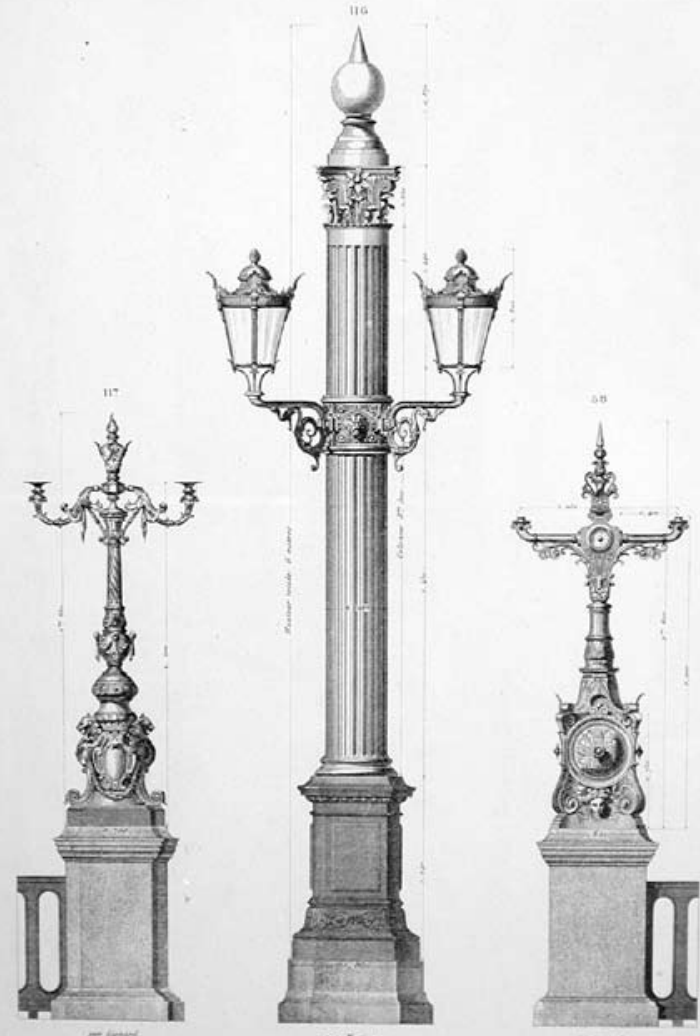
d'Osne Foundries of the last third of the 19th century

Version of the simple lamppost by Hittorff in Barcelona, Plaza de Catalunya

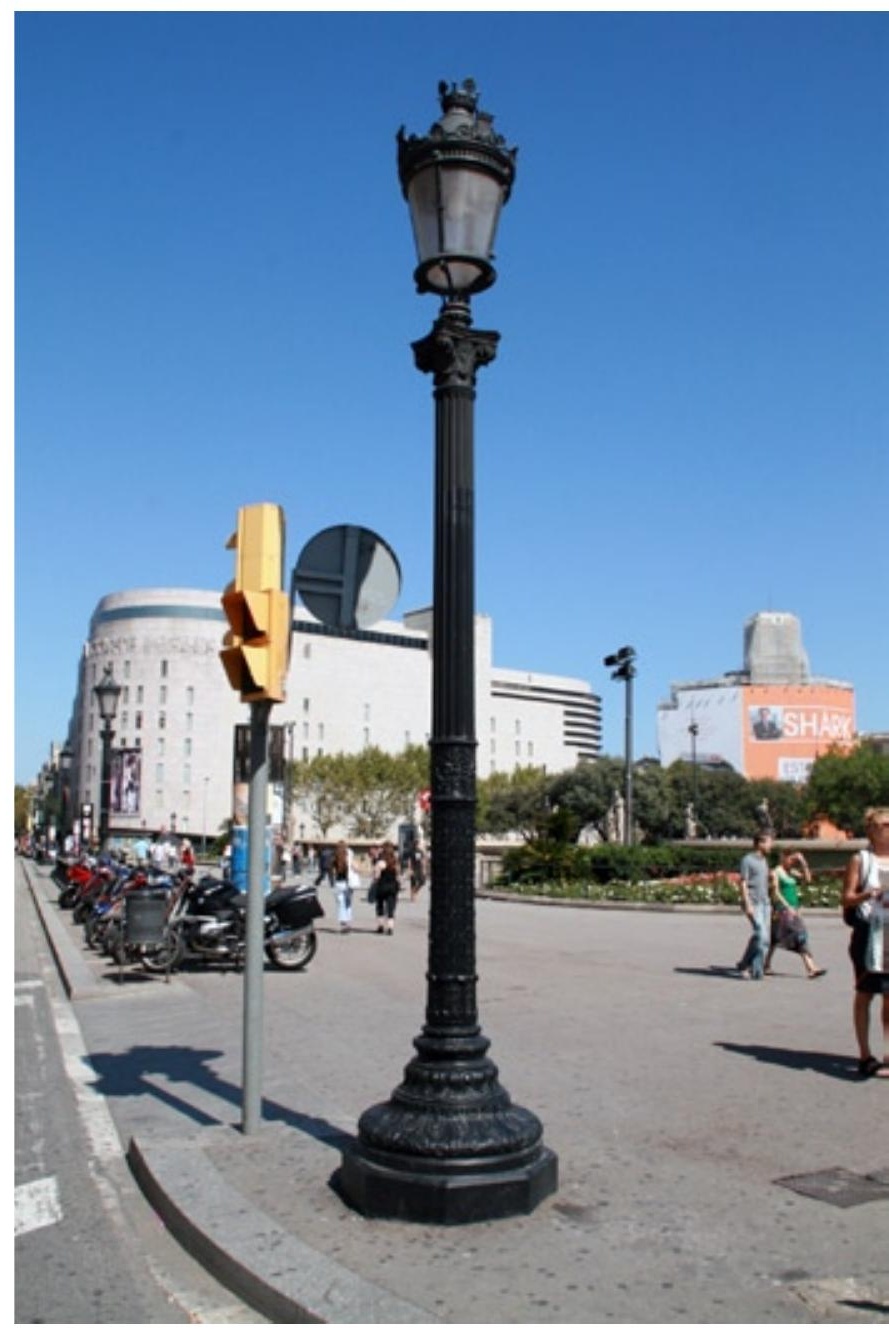




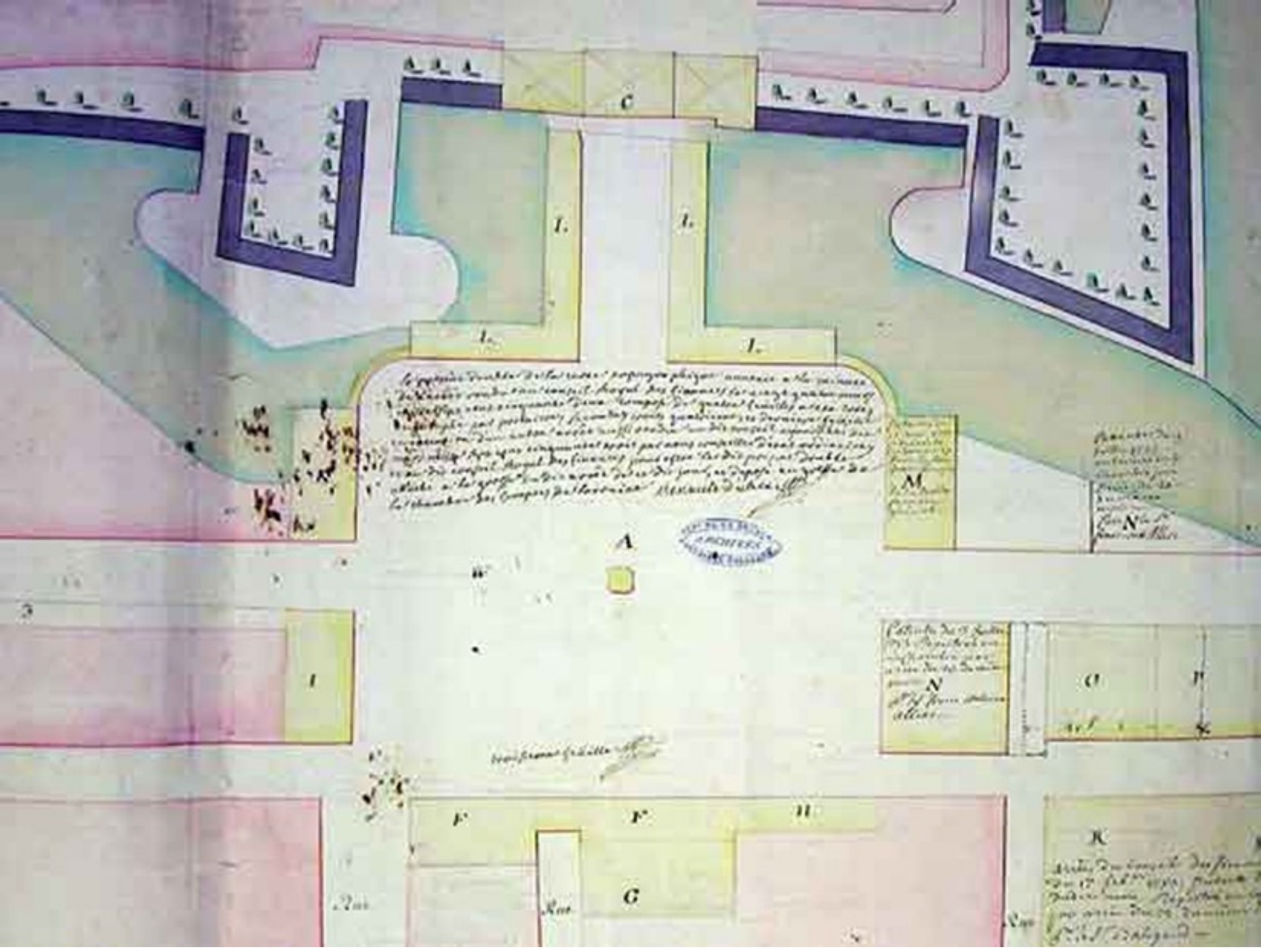

Nancy. Plan annexé à la minute de l'arrêt du Conseil royal des Finances du 24 mars 1752. II indique la partie méridionale des fortifications de la Vieille-Ville et les emplacements des constructions de la place Royale. 1752

\section{Nancy Stanislas square.}

The square, the royal square where the statue of Louis XV was installed, was a major project in the urban planning imagined by Estanislao I Leszczynski, Duke of Lorraine and former King of PolandLithuania, as a way of joining the old medieval city of Nancy and the new city built by Duke Carlos III Lorena in the 17th century. The design linked two buildings that already existed, the Hôtel de Ville, today centered on its large square, and the Hôtel du Gouvernement. The seat of the municipal government and the seat of the ducal government were face to face as complements through a series of rational, symmetrical, and still varied and unparalleled urban spaces in the Europe of its time. (Caillaut 2008)

The square and the surrounding buildings, unified by their colossal order, were designed by the royal architect Emmanuel Héré de Corny. Construction began in March 1752 and ended in November 1755. In its beginning it was called Royal Square Luis XV and was one of the first royal squares in France. 
Barthélémy Guibal and Paul-Louis Cyfflé created a bronze statue of Louis $\mathrm{XV}$, which rose in the middle of the square until it was removed during the Revolution and replaced with a simple winged figure. The square was renamed Place du Peuple, and later Place Napoléon. In 1831, a bronze statue of Stanisław (Stanislas in French) was placed in the middle of the square, since then known as the Place Stanislas, in honour of the last Duke of Lorraine. (Hallays 1920; Syndicat d'initiatives, 1931).

Duke Stanilas, founded, a few years later in 1765, the park of the Pépinière that receives its name and its grid design to its original function: royal greenhouse, in order to supply trees to plant on the roads of the Lorraine region. Despite its transformation into a park open to the public in 1835 , the layout of the sixteen squares of cultivation beds has been preserved and can still be seen today in the perpendicular layout of its avenues.

At the entrance of the park, facing the Stanislas square, two monumental fountains, works by Dieudonné-Barthélemy Guibal, close the northern corners of Place Stanislas. They lead sculptures for the sake of economy. If sources are monumental, no less so are the gates that mark the separation between the square and the entrance to the park. In the past, these fountains were not only decorative, the small fountains serving as drinking troughs for horses, the large ones serving water to the inhabitants.

The examples of Paris and Nancy illustrate the importance of public space. An open and multifunctional space is the mechanism to joint two different parts of the city, detached one of the other. In the middle of each square a Monument [both dedicated to Louis XV], together with some additional elements, such as fountains and architectural elements. Around a monumental vertical plane built by the facades of the buildings, the green of the gardens or the open blue of the river. 


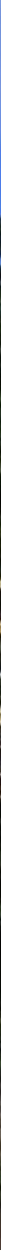

Hegemann and Peets (1922:69) thought that this square was "the most wonderful of the plazas built in honour of King Louis, was an architectural creation in the strongest sense of the word. Much more than an ordinary plaza, it represented a group of plazas comprising the square with the centrally located monument of the King and what might be considered as two forecourts to this main plaza; the long "Carriere" with its clipped trees and the oval colonnaded area in front of the Palace which faces the City Hall at the other end of the long composition". On the other hand they affirm that the "Place de la Concorde partook more of the landscaped character of a large American campus"

Neptune Fountain

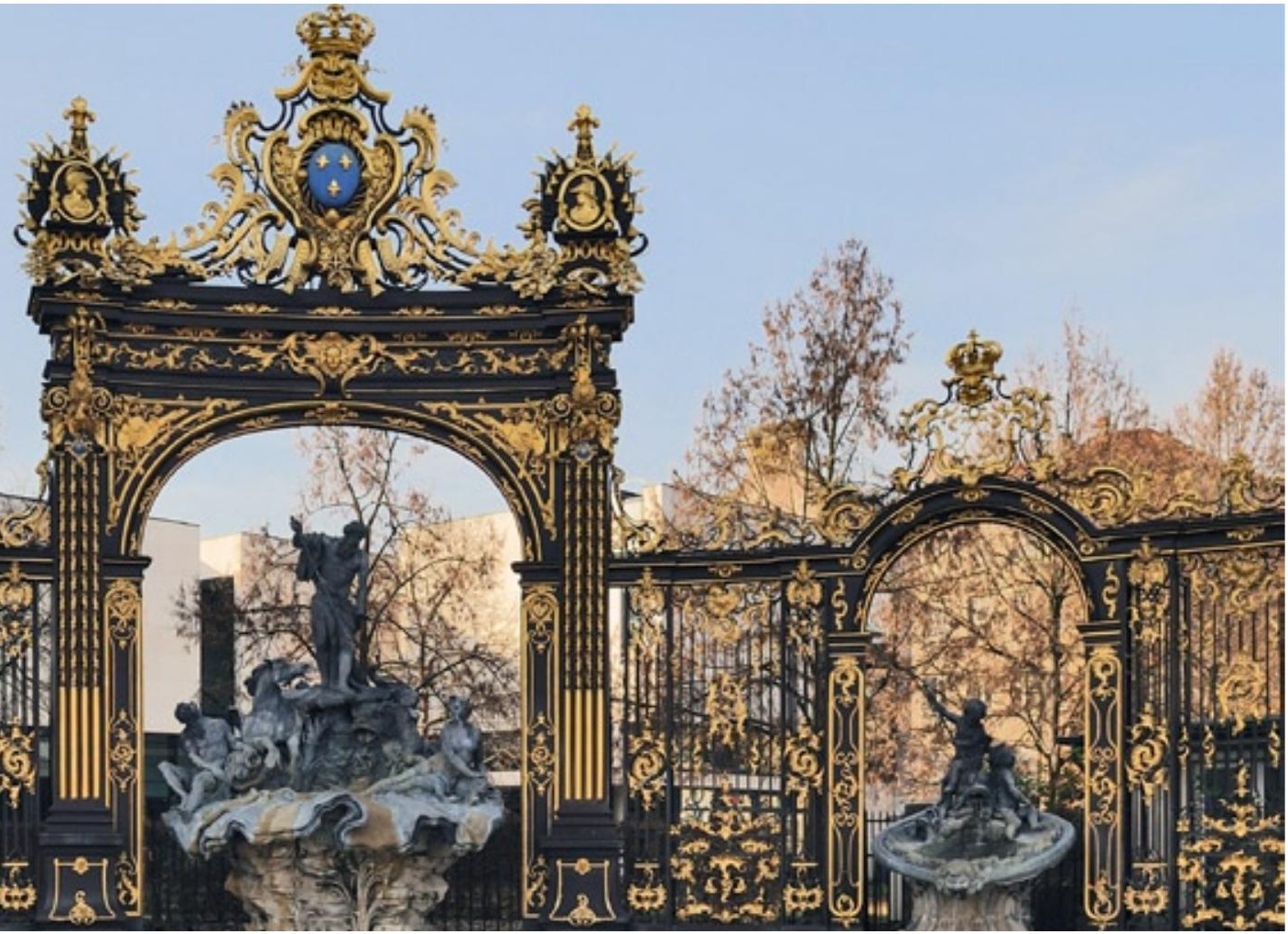




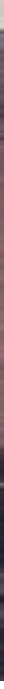

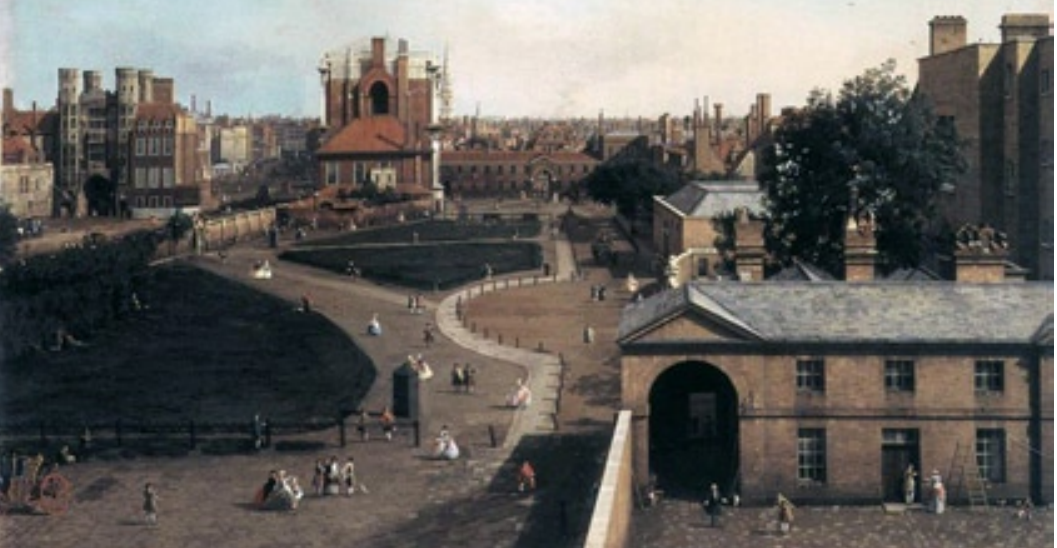

London [up] Canaletto (Giovanni Antonio Canal) c.1749, London: The Old Horse Guards from St James's Park (C) Tate.org.uk

[below] Canaletto (Giovanni Antonio Canal) 1747. London: Whitehall and the Privy Garden from Richmond House (C) Web Gallery of Art, https://www.wga.hu/ html_m/c/canalett/7/canal704.html

\section{London. Saint James Park and the Mall}

St James's Park is a 23-hectare (57-acre) park in the City of Westminster, central London. In 1532, Henry VIII purchased an area of marshland through which the Tyburn flowed. It lay to the west of York Palace, subsequently renamed Whitehall.In 1630, James I ordered that the park be drained and landscaped, and exotic animals were kept in the park, including camels, crocodiles, an elephant and exotic birds, kept in aviaries.

While Charles II was in exile in France under the Cromwell's Commonwealth of England, (1649-1653) he was impressed by the sofisticated gardens at French royal palaces, and when coming back to England, he ordered to redesign the park in a more formal style, probably by the French landscaper André Mollet. A 775 metre by 38 metre canal was created. The king opened the park to the public and used the area to entertain guests and mistresses. In the late 17th and early 18 th centuries cows grazed on the park, and milk could be bought fresh at the "Lactarian". The 18th century saw further changes, including the reclamation of part of the canal for Horse Guards Parade 




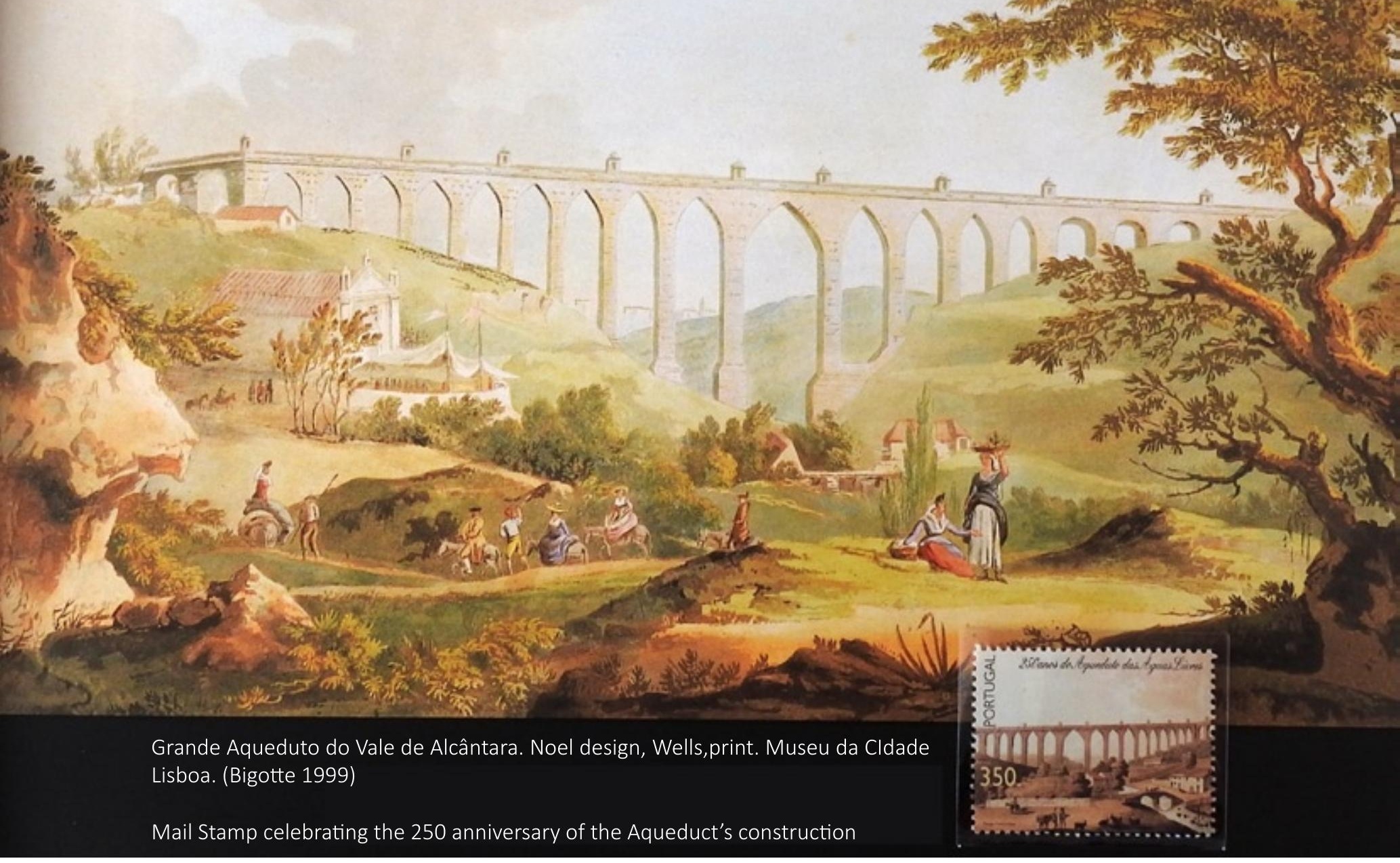

were both called upon to bear the brunt of the costs of this work. The tax that the local population had to pay for this purpose, known as the Real D'Água, dates back to 1729, and was levied on staple foodstuffs, such as wine, meat and olive-oil. The building of the Águas Livres Aqueduct was completed in 1799, and, in 1834, the Mãe d'Água reservoir in Amoreiras was finally ready for use.

The responsibility for designing the most significant works of the period of Dom João's reign was handed to foreign specialists, and this hydraulic structure was included in this group. Several foreigners were involved in the design of this aqueduct, working there as architects: António Cannevari, Carlos Mardel, João Frederico Ludovice, Miguel Ângelo Blasco and Theresio Micheloti, as well as other surveyors and master stonemasons. The various stretches that were built are the result of the work planned by the different people responsible for overseeing the aqueduct's construction, the most notable of whom were the Portuguese military engineers Manuel da Maia (1732-1736) and Custódio Vieira (1736-1744), as well as the Hungarian military architect Carlos Mardel (17461763).

The Aqueduto das águas livres, forms a water distribution system to the city. A part of the route is uncovered, but when it enters the city the aqueduct remains buried. In order for water to reach people, be they private individuals or professional water carriers -which, in Lisbon, were called "galegos" (Galician), because many of them came from Galicia in Spain- an interface of use is needed. Lisbon will opt for what Quatermère de Quincy (Quatremère 1788) called "fountains in archi- 


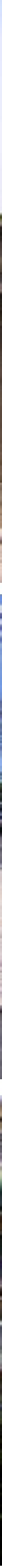

Obelisks / Canopy fountains in the "Agoas Livres" System in Lisbon
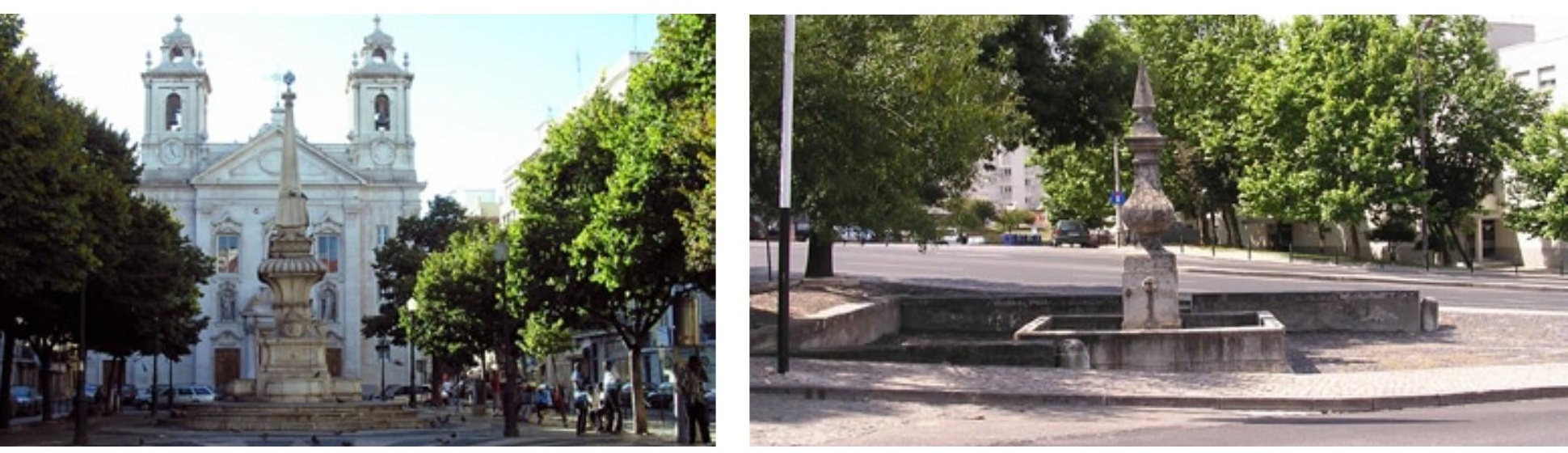
During the 1755 earthquake, the aqueduct resisted its attacks quite well, unlike the most populated area of the city. Due to earthquake's destructions all over the city, Lisbon does not offer us a good example for the study of the evolution proposed in the previous scheme. In addition, Lisbon is incorporated later than other cities (see the case of the Plaza Real de Barcelona or Vienna) to the installation of jet water fountains in the public space.

The reason is that most of the XVIII and XIX century "chafarices" are water towers. Another reason could be the enormous weight that the Pombaline dispositions about the building systems and models of the Baixa Pombalina, have on the whole of the building activity in the city that was determined by the provisions of the central government and not of the authority municipal. Added to this is a very widespread and popular culture called "architecture chã" (plain architecture), in which the simplicity, a certain standardization of materials and stonework are fundamental (Cunha 2005) .

Therefore we must find an answer to this evolution in another place and we will resort to a brief description of the evolution of fountains in Vienna

\section{Vienna fountains. From drinking to ornamental fountains}

\section{Fountainhead}

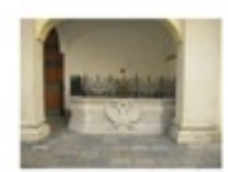

Sculptural

$$
\text { drinking }
$$$$
\text { fountains }
$$

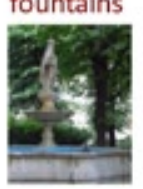

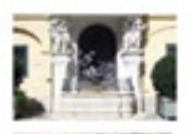
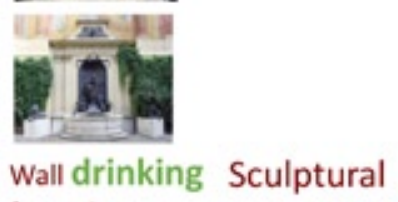

fountains

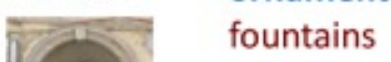

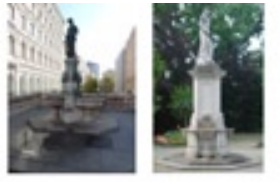
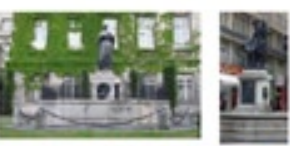

Sculptural drinking fountains

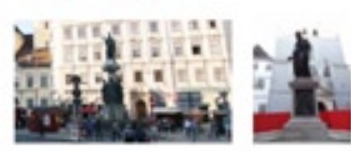

XIX C.

XVIII C.

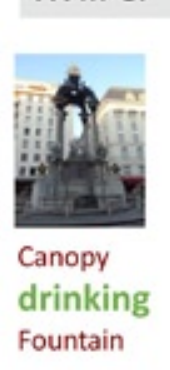

Canopy drinking

Fountain

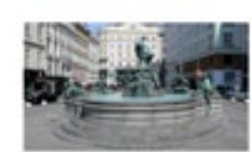

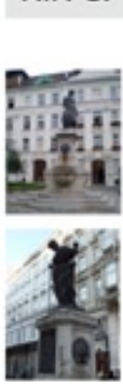

Sculptural ornamental fountains

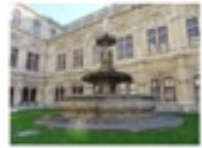

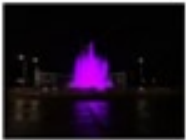

Water jet ornamental fountains + light

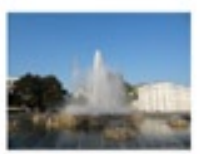

XVIC.

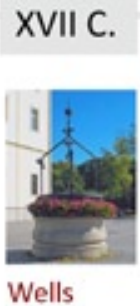

Vienna, as the capital of an empire, has a long tradition in the construction of fountains, first to provide water to citizens, then, since the mid-nineteenth century, as elements of urban decorum in the articulation of the new city, the new city that would grow on the other side of the old walls, converted into a belt to articulate between the old and the new Vienna, through the "Ringstraße". The 'Ringstraße' is a great avenue that completely surrounds the old town of Vienna or Innere 
Stadt. It is one of the main avenues and one of the most important boulevards in Europe, with its $5.2 \mathrm{~km}$. long and 57 meters wide in most of its sections.

When in 1850, Vienna annexed some of the nearby villages. It became clear that the historic city walls, which were the protagonists of the various sieges, had become obsolete and were a hindrance to the growth and expansion of the modern city, as in most European cities. In 1857, Emperor Francis Joseph I issued a decree "is my will" (Es ist Mein Wille) ordering the demolition of the old city walls. In this decree the emperor already defined the exact size of the round to be built instead of the walls and the esplanades along its entire perimeter, as well as the location and functions of the new buildings to be built in the land that was freeing up.

Numerous green areas and parks are scattered around the Ringstraße, most notably Stadtpark, Burggarten, Volksgarten and Rathauspark. Among the squares are Schwarzenbergplatz, Schillerplatz, Maria-Theresien-Platz and Heldenplatz. There are also numerous monuments and statues.

The plan also entailed a change in urban infrastructure, especially with the provision of new urban services (water, gas, and subsequently electricity). Maintaining the drinking fountain program, the new public spaces required another use of water, with the development of an ornamental fountain program.

In previous scheme of the different solutions taken to deliver water to cities and ensure their distribution through fountains. It describes the fountains gradual ornamentation as well as changes in the handling of hydraulics favouring the sliding of the use of water from the primary necessities to others of a more festive and symbolic character. What is clear is that for XVIII century there is a trend to change drinking fountains from the backed to the isolate ones, a change from "fountain in architecture" to "fountains in sculpture". Furthermore, we can appreciate a gradual incorporation of jet water fountains into urban scene, profiting from the hydraulic experience in the ruling class gardens with the development of several water features. Maintaining drinking fountains as a service for citizens, little by little, the use of "ornamental water" in the city is gaining weight in the fountain system. 


\section{Series of copies: a first step in democratizing Art.}

Ninetieth Century is a time when Europe and the USA live the boom of the use of iron as a construction material, both for building and for infrastructures. Bridges, towers, markets, libraries, elevators (Rovira 1899). But iron is going to play an important role in the processes we can call "urban landscape normalization." Indeed, the implementation of urban renewal projects in England after the 1666 great fire (Benévolo 1975; Kostof 1992, 1995) and in France, especially in Haussmann's Paris (Haussmann, 1893; Pinon 1991), are associated with the city grid's design and the arrangement of the vertical plane of the public space, but the importance of the horizontal plane, that of the ground, in which the true normalization of contemporary public space is going to occur is rarely considered. And cast iron will play a central role. Everywhere iron works companies start to develop elements of urban furniture, street benches, kiosks, street urinaries, lampposts, tree grilles .... in parallel to the foundry elements necessary for the construction of machinery. But, also, ornamental works that, in many places, are going to replace the monuments of stone, bronze or lead.

The analysis of how the Fountain of the Three Graces comes to Barcelona is illustrative of the process. At the site of the fountain, there should have been a monument dedicated to Ferdinand Il of Aragon, the Catholic King (Molina, 1850). This is no time to dwell on the monument, although it is a more than curious story of frustrated monument, which was and was not, in the style of the Galheteiro in Praça do Rossio in Lisbon (Águas 2009, 2013).

What is certain is that the City Council, through its chief architect of Buildings, Ornamentation and Plumbing, and subsequent winner of the Ensanche contest, Antonio Rovira Trias, buys in 1876 a cast iron from fountain from the French company Durenne, which It has offices in Paris, and a representative in Barcelona. According to the administrative file in the Archive of Barcelona, signed by Rovira

This fountain would avoid the monotony and coldness that is observed in one of the main squares of this city since the current water spout lacks the ornamentation that corresponds to it. This fountain could be cast iron and in this case it would cost its entirety, that is, foundry expenses, bronze color paint, placement, pipes, etc., etc., the amount of eleven thousand pesetas. (Rovira 1876)

The fountain of the Three Graces has become an urban icon of Barcelona. However, it is curious to analyse its symbolic content. In Barcelona, until we began our investigation, (Remesar et al., 2010) the Fountain of the Three Graces had no other content than that of being the central ornamental element in the Plaza Real. But, this fountain is, in origin, a funerary monument. Indeed, the original sculpture by François Pilon, 1560, is the reliquary for the heart of Henry II of France, ordered to be built by his wife Catherine de Medicis in the church of the Celestins in Paris and currently in the Louvre Museum. All of Europe is filled with reproductions of what are considered the best pieces of antiquity and the Renaissance. First in plaster, then in cast iron.

How does this sculpture, better this copy, reach the streets of Barcelona and other cities? It is well known that European Enlightement, partly as an educational procedure, partly as an ideological 


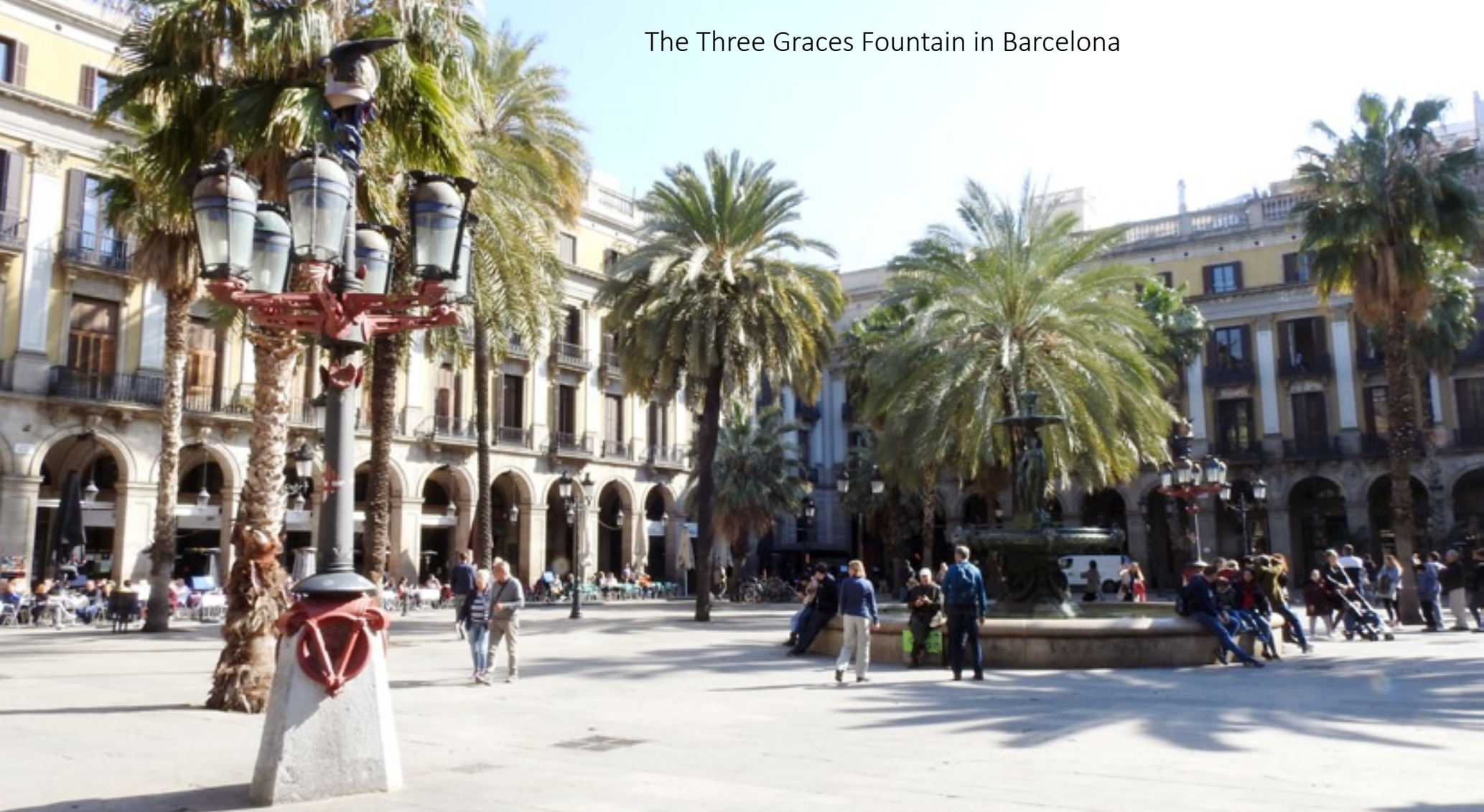

The Fountain of the Three Graces is in the center of the royal square, flanked by the two street lamps designed by Gaudí in 1879

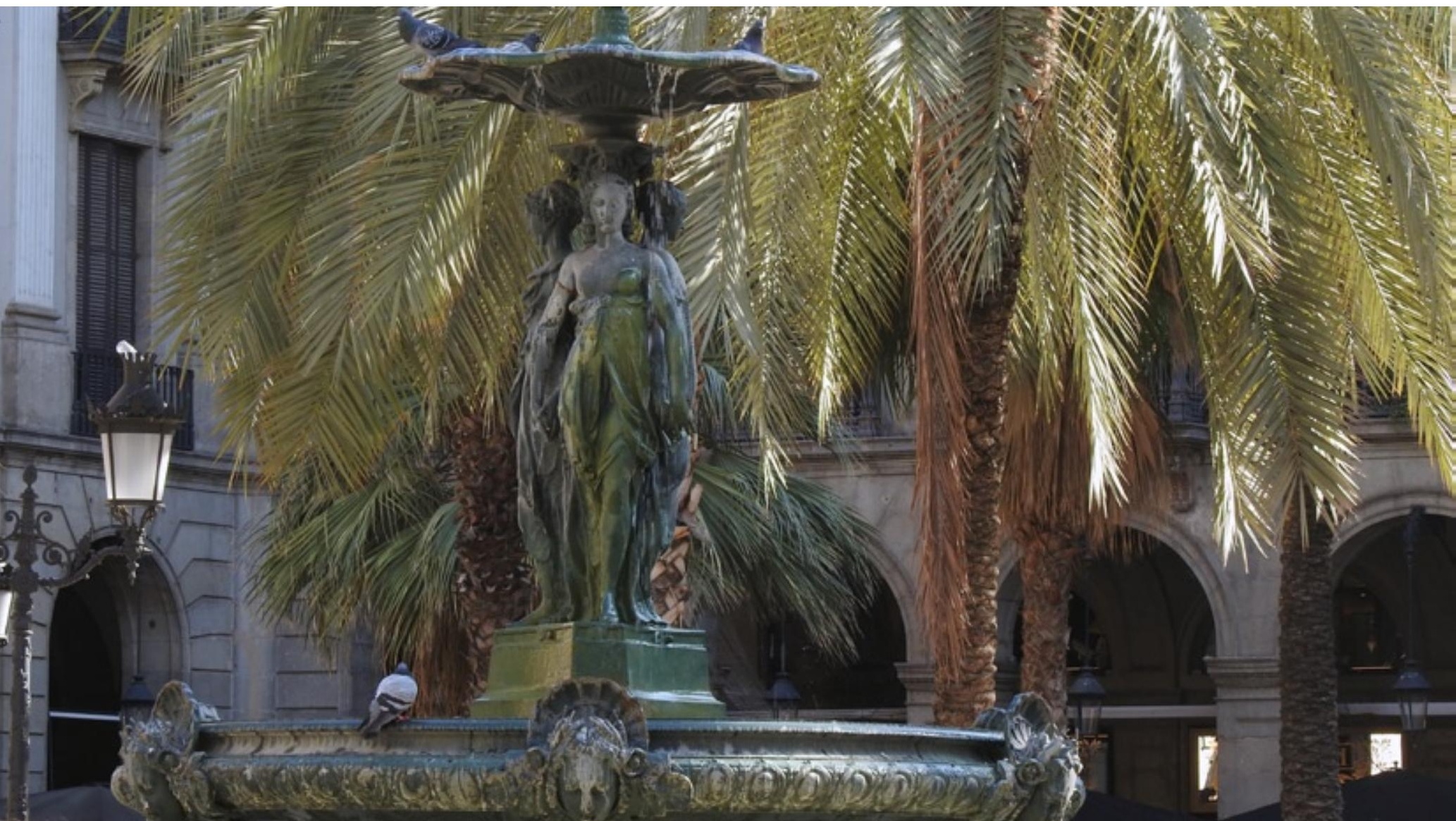




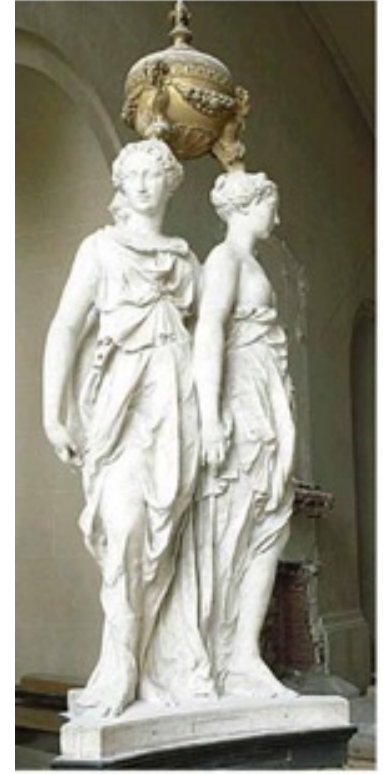

1560 F. Plon

Monumento para el coraźn de Enrique II

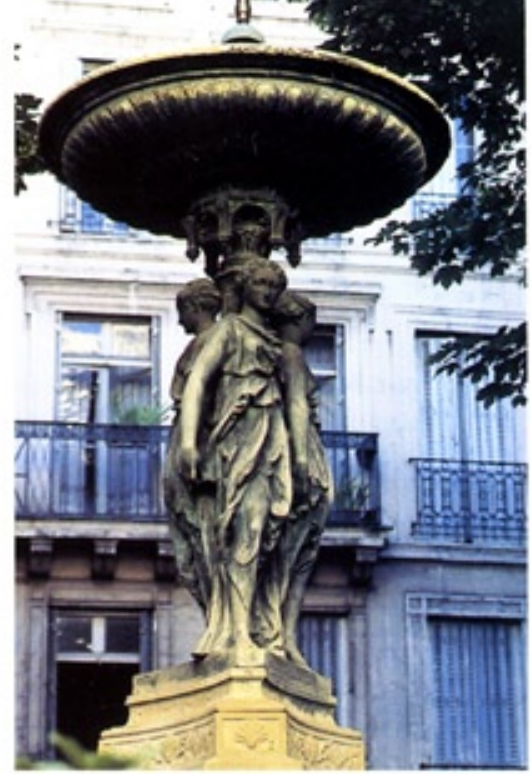

1845 F. J. Duret (Fund. Ducel)

Forkane de Trévise

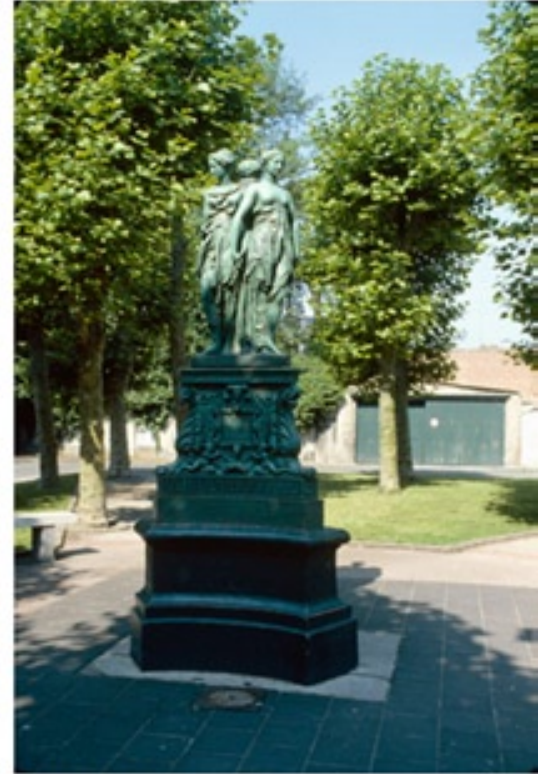

1655 J.J. Ducel

Les trois Gräces

From original to serial reproduction. Different models of central sculptures in Lima and Valencia
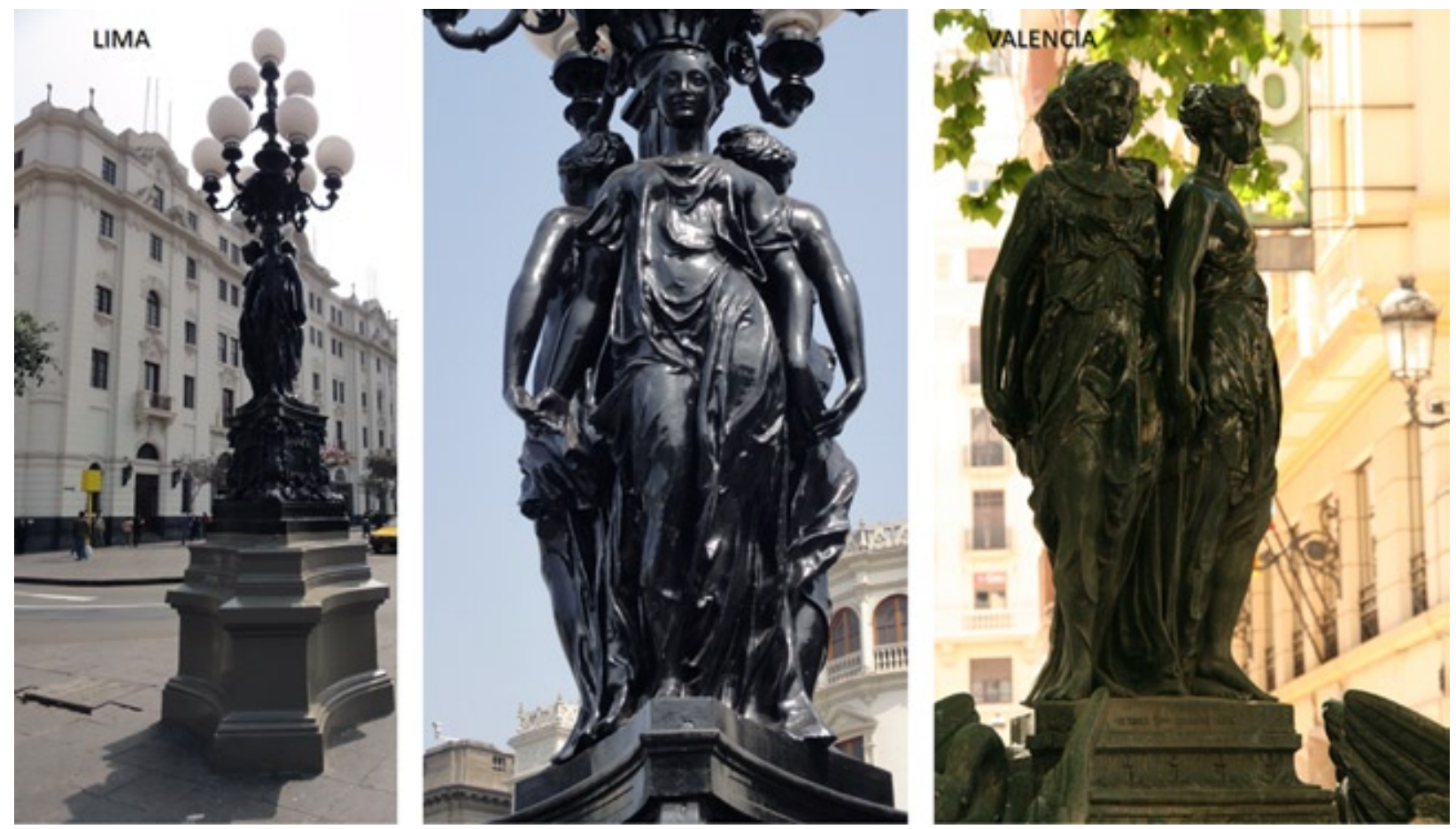

instrument of fixing the symbolic universe, instituted the copy of the classical models as a normal procedure, both for the reproduction of the art pieces or for their enjoyment. Europa entera se Ilena de reproducciones de las que se consideran como mejores piezas de la Antigüedad y del Renacimiento. All of Europe is filled with reproductions of what are considered the best pieces of antiquity and the Renaissance. First in plaster, then in cast iron. To do so, Museums allowed a number of companies making molds for subsequent transfer to stone or metal. This practice was also enhanced by Napoleon I, through the Louvre's copy workshop founded in 1794 as a strategy for the maintenance and dissemination of French national heritage. (Rionet 1996) All data show that the "mould" of the Three Graces piece was made at the beginning of the 19th century, since Louis Visconti designed the Fountain of the Three Graces in 1833, and in 1845 we can find a version in the Placette de Trévisse in Paris signed by Francisque Duret. In 1855, J. J. Ducel presented the total copy of the reliquary at the Paris International Exhibition. 
Project by Rovira in order to convience the City Council to buy the cast iron fountain
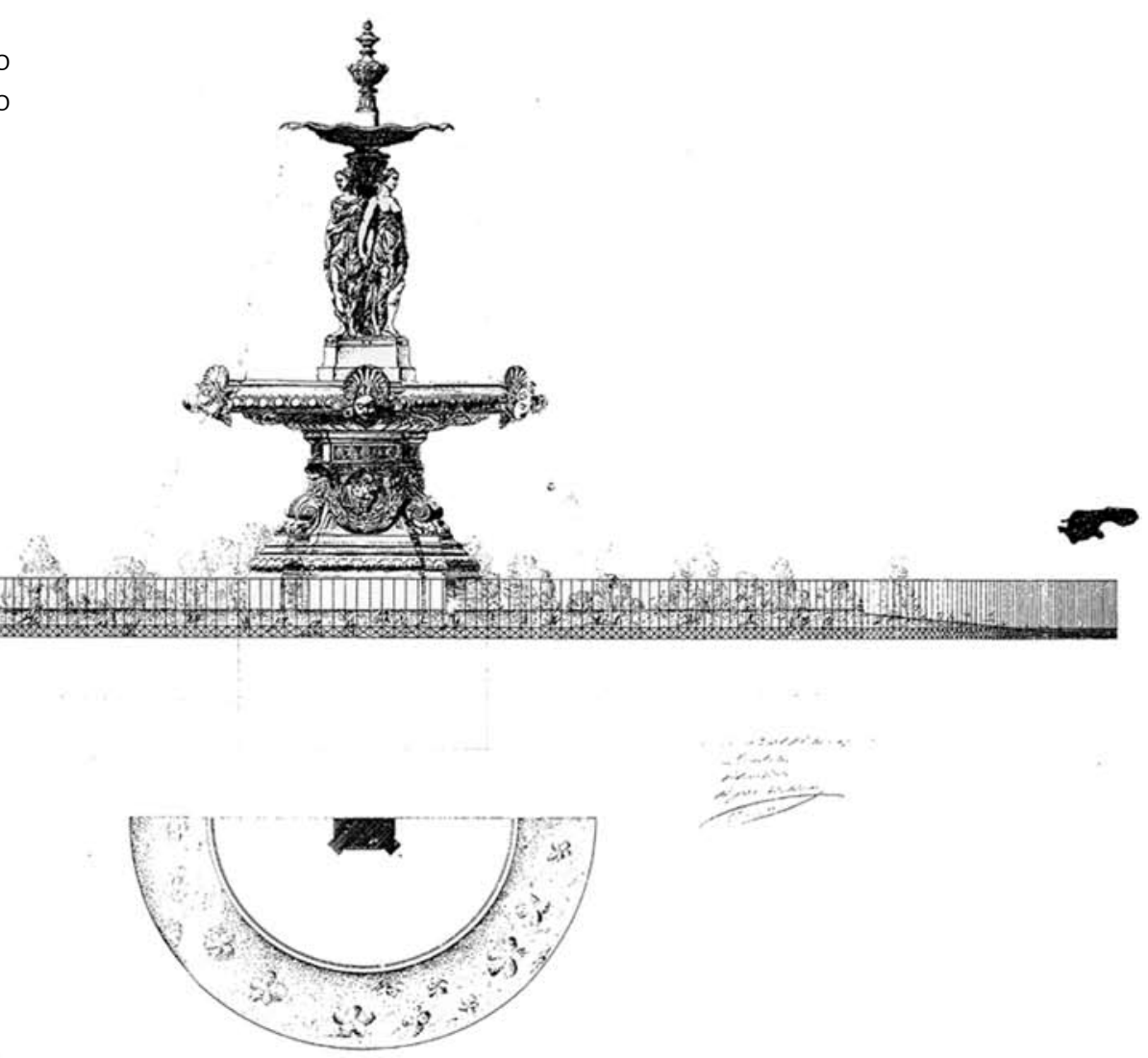

The commercial representatives of the foundry companies were responsible for convincing municipal architects of the suitability of their products, basically based on three sales arguments: [1] The modernity involved in the use of iron, [2] the creation of an "international" image of the city by placing what was most "trendy" in Paris, and [3] the economy translated into costs, duration and maintenance. An additional selling item was that of product customization. Indeed, work on casting allows relatively easy to organize a set of materials in a quite varied layout and presentation. (Remesar, et al., 2010; Remesar, 2004a).

The philosophy used by Napoleon was to make affordable the masterpieces possession of the Ancien Régime to all citizens, on the one hand thanks to the Museum and the formation of French Heritage, on the other by replicating, copying, masterpieces for dissemination, which would enable, also, the formation and development of a thriving industrial sector. The procedure for copying and serial production is not new. Let's think about the role that the printing had for the dissemination of texts hidden in monasteries and royal libraries, or the sales boom of engravings throughout the sixteenth, seventeenth and eighteenth centuries, thanks to which authors such as Hogarth were able to support their artistic work. 
Brief timeline / atlas of the Fountain of the Three Graces in Barcelona

1848

Public contest for the creation of a square, named of Catholic Kings, won by Francesc Daniel Molina.

Public contest for the equestrian monument initially dedicated to Pedro III the Great. Finally, the project will be for José Piquer with the equestrian statue of Ferdinand II, the Catholic

1850

Laying of the first stone coinciding with the anniversary of Queen Elizabeth II. The square starts to be named "Royal"

1851

Three drawers with elements of the monument arrive from Madrid

1855

The name Plaza Real is confirmed

1857

Pedestal Construction

1860

A plaster copy of the Monument is placed

1861

The plaster copy begins to deteriorate. The statue is removed and only the pedestal remains

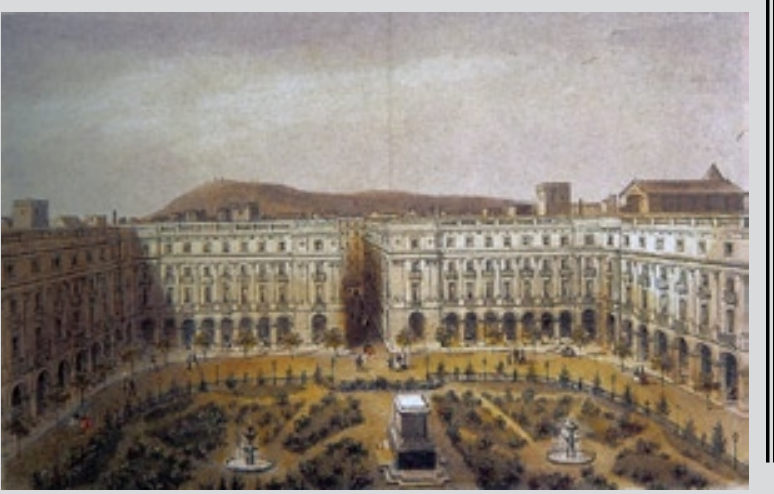

1718 Capuchins' Convent

1822 The convent passes to the City Council. The square is named "Spanish Heroes"

1835 Burning of convents

1841 Public contest to create a theatre in the former site of the convent and orchards of the Capuchins

1842 to 1848 The so-called New Theatre operates
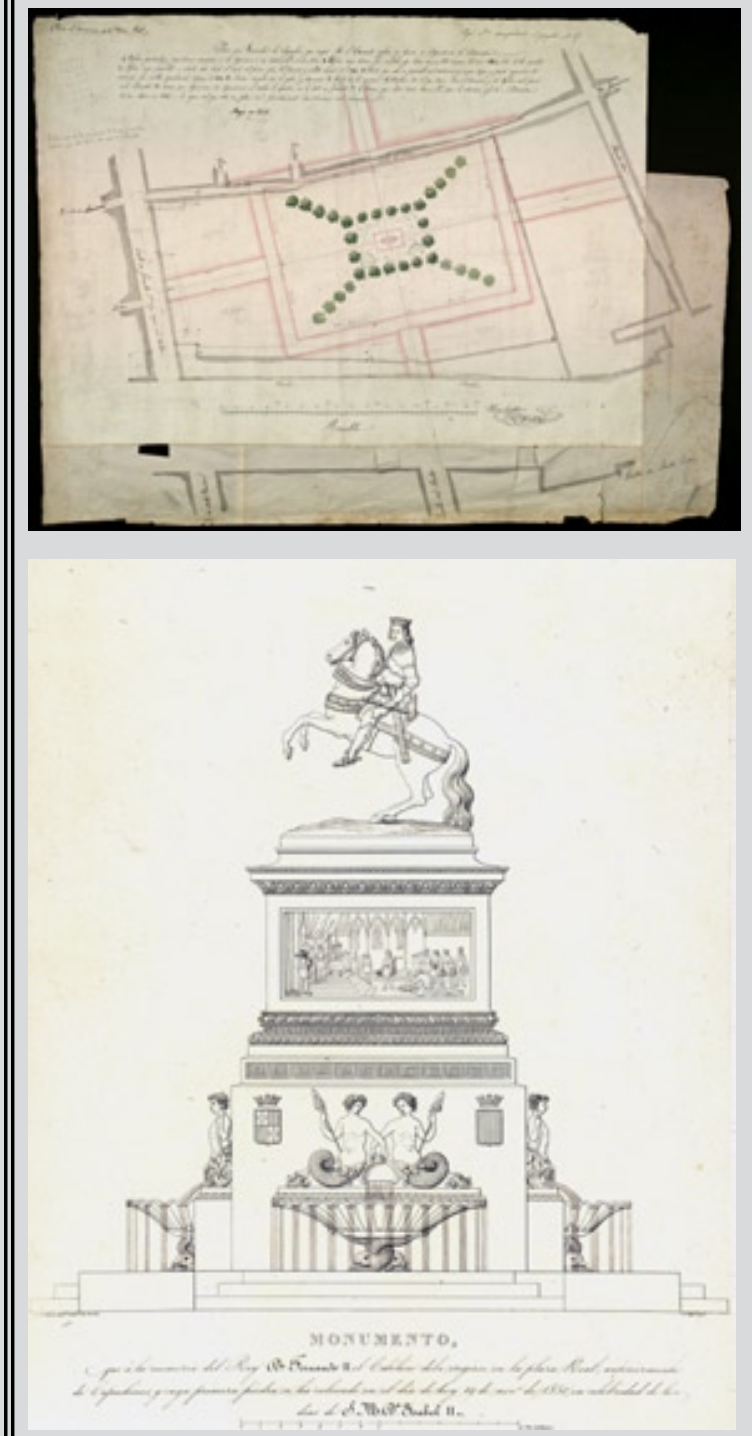

1865

The remnants of the sculptural elements are stored in the Town Hall 


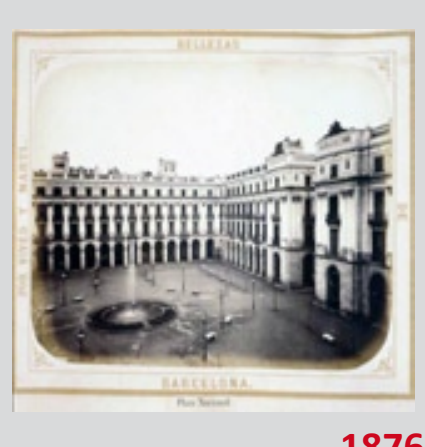

1876

The jet water is replaced by the Fountain of the Three Graces

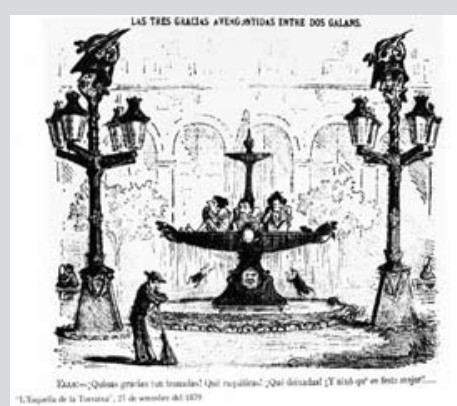

1888

The Fountain is replaced by a luminous jet of water
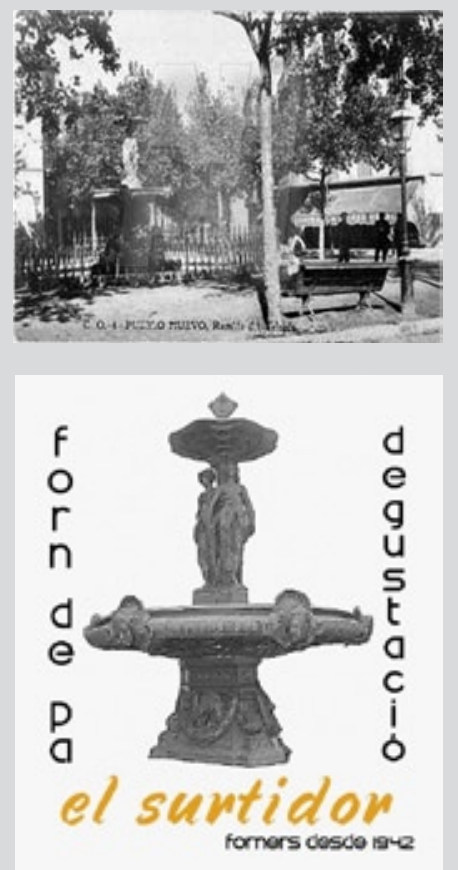

\section{c. 1868}

A jet water fountain is placed at the monument site

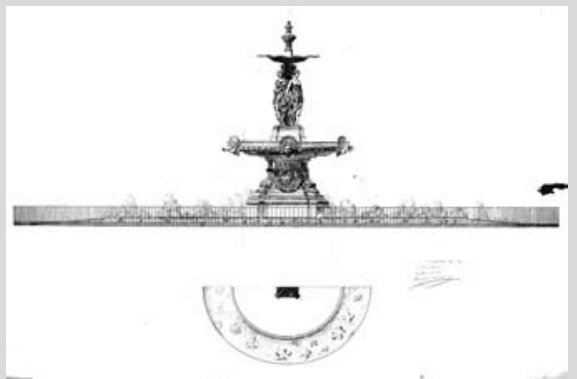

\section{9}

Gaudi's project for installing four lampposts. They will not be installed until 1879 and only two

\section{6}

It is arranged to build a monument to Jaume I, the conqueror, in the Plaza Real

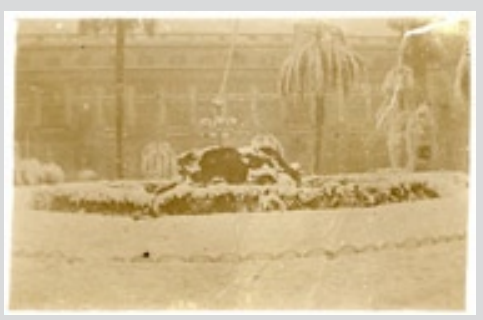

\section{$1907-1925$}

The Fountain is installed on the Rambla del Poble Nou. Some stores still remember this fact, i.e. "Bakery the jet of water"

Remodelling of the gardens of the Plaza Real by N.M. Rubió i Tudurí. The Fountain is reinstalled 


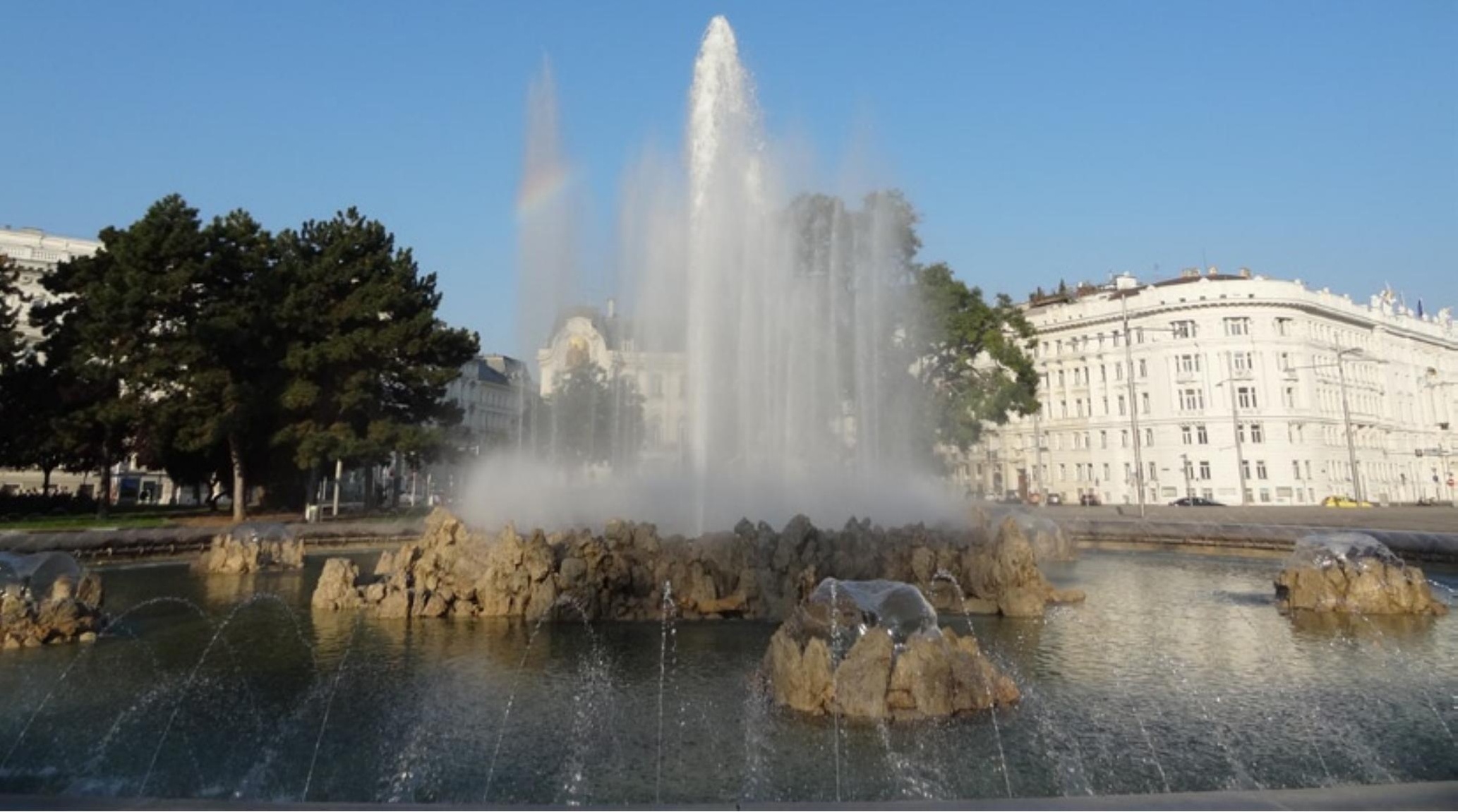

Hochstrahlbrunnen. This fountain celebrates the arrival of new waters in Vienna. As we saw in the case of the Plaza Real in Barcelona, at the end of the 19th century, there is a tension in reference to the ways of raising a fountain. A tension that is initiated by the change in functionality. These new sources are no longer to provide water, but have a fundamental mission of urban decorum. At the same time, given the technical characteristics of the fountains, water becomes the subject of a sculpture without matter, tilting figurative interventions based on volumes that occupy space. "Water sculptures", are dynamic, introducing movement and even sound and generate a changing form, in a space regulated by means of a choreography. Aspects quite well known by Le Nôtre, Vanvitelli and others, when they designed de scenography of the huge royal gardens since the midseventeenth century. In addition, the inclusion of electrical mechanisms allows this choreographic game to incorporate color. Even later, sound. These "water sculptures" need a detailed study and technical design and represent a paradigm shift in projects for monuments in public space.

Anton Gabrielli, building contractor of the water pipe, donated 200,000 crowns for the construction of the fountain, which was carried out on behalf of the city of Vienna by the building contractor Gustav Bruck. In 1886/87 extensive considerations were made regarding the regulation of Schwarzenbergplatz and, in connection with it, the new version of the Hochstrahlbrunnen. The designs of the important sculptors Viktor Tilgner and Rudolf Weyr were presented to the public at 


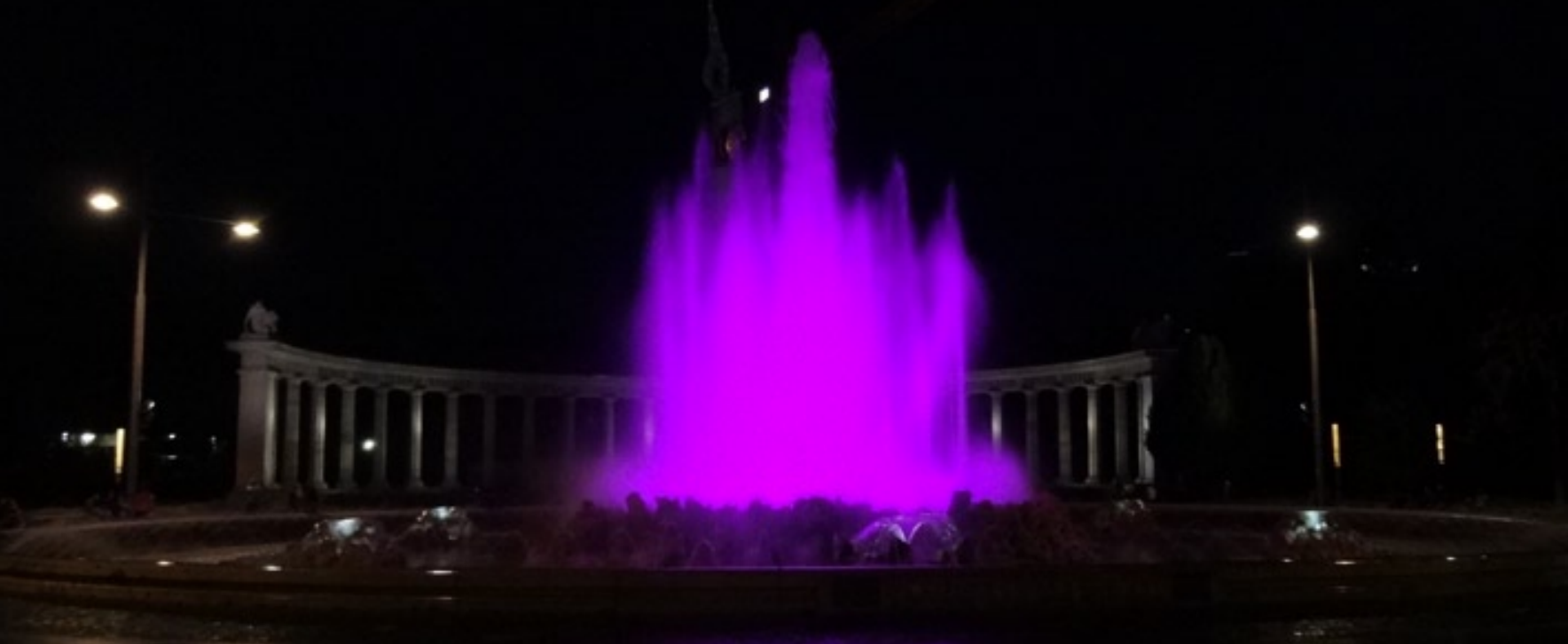

the Vienna Künstlerhaus from the end of January 1887, however, no decision was made in their favour.

The original nozzle arrangement from 1873 consisted of one high jet for the year, four jets in the inner stone island for the seasons and 365 edge jets for the days of the year. Today, at the edge of the pool there are 365 small fountains that symbolize the days of the year. The six fountains between the pool edge and the inner island correspond to the seven days of the week. Twelve water high jets symbolize the months, 24 low jets the hours of the day and 30 jets in the middle island the days of the month. Later, the fountain, in the style of a fountain lumineuse by the architect Oskar Marmorek, was converted into a light well at a cost of 285,000 crowns, which opened on June 23,1906 . At night it glows in the colours red, pink, yellow, violet, blue and green.

As hydraulics techniques advanced, some cities opted for a monumental use of water. First with the creation of true monuments to the water, as is the case of the monumental fountains of Marseille and Barcelona. The subsequent technical sophistication allowed us to move towards the idea of "water as a show" by incorporating light and even sound into a fantastic choreography of water features. 
Olsen, in his work analyzing the case of beautification programs in London, Paris and Vienna, described what would largely become the paradigm of urbanization of large cities from the midnineteenth century until the emergence of the paradigm of the Modern architecture:

The three programs shared a series of characteristics: [1] they resulted from the initiative of the central government, depended, for their success, on the attraction of private investment by speculative builders and developers. [2] They were intended to make royal or imperial residences more prominent; public parks created; mixed public and private buildings, ecclesiastical and secular purposes, residential and commercial uses; the architecture used mainly in the classical tradition; put monuments of national, imperial, dynastic or cultural importance; build wide streets to facilitate traffic and serve as fashionable walks; and [3] combine aesthetics with social and health reasons (Olsen, 1986).

Although the state representation conditions described by Olsen do not occur in non-capital cities, the whole program is easily subscribed by any city that has industrial and commercial capacity. Worlwide the areas that border water are undergoing a gigantic change in recent years. But this change had already begun mid the 19th century.

\section{Finally, public space for all [may be almost all]}

At the today's Battery Park site, New York, there were a number of military defense batteries beforehand. In 1807, to prepare for the future British invasion and war, New York City cedes land from The Battery and around the city coast to build five new forts to protect New York Harbor. Among those are Castle Clinton on The Battery, Castle Williams on Governors Island and Fort Wadsworth on Staten Island.

In 1823 the federal government orders the removal of Castle Clinton's military base and rents out the place in New York City. The area is called Castle Garden, and the building is open to the public as an amphitheater. It featured the Eugene Robertson Hot Air Balloon Rise in 1825, and later housed a circus. Over the next thirty years, the building expanded to include a second floor, a roof, a fountain, and was improved with streetlights. It works as an opera house and theater, with a rooftop walk. Later, it will host an aquarium.

In 1850 The Landscaped Battery becomes a popular walk on the Hudson River and Castle Garden becomes one of the most important arts and entertainment venues in the city. In 1855, the embankment, connecting Castle Garden Island with the mainland, expands the park area. In Battery Park New York State sets up an immigrant landing site in the castle building. Over the next 35 years, 8 million immigrants are processed here. Notable Americans for passing Castle Garden are Nikola Tesla, Harry Houdini, Emma Goldman, or Joseph Pulitzer. In 1940, Robert Moses introduced controversial plans to build a bridge from Battery to Brooklyn. Local residents and activists, with the support of Eleanor and President Franklin Roosevelt, protest the development and stop it. 


\section{Battery Park Promenade. New York}

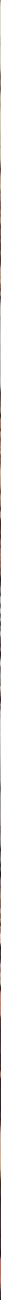

Currier \& Ives \& Equitable Life Assurance Society Of The United States. (1883) The city of New York. [S.I] [Map] Retrieved from the Library of Congress, https://www.loc.gov/ item/97683571/.

Until well into the nineteenth century, many of the malls and parks studied should not be properly considered public space. The images of Saint James Park, both those of Canaletto and the engravings, clearly indicate this. They were open spaces "to the public", that is to a certain audience, formed by aristocrats, military, merchants, bourgeois, clergymen. The presence of the popular classes is not evident, beyond those characters that by their function linked to the "gentlemen" (stable boys, equerries) or the work to be carried out in the public space itself (the workers of the "Lactarian"). Thus, we cannot say that they are spaces of exclusion, but it is clear that they are not inclusive spaces, a fundamental mission of public spaces. It is not by chance that the term "Mall" is used today to designate the large shopping centers that replace outdoor walks. The today's "Mall", like "The Mall" would be rather collective spaces in which the property determines the rules of use and behaviour (Cerasi 1976; Gutiérrez 2017; Solà-Morales 1992). These collective spaces, unlike public spaces, are governed by the rules dictated by the property, based on "the right of admission" - not everyone is welcome- and by their strict physical control and access (guards, cameras , etc)

It will be from the liberal revolutions of the second half of the nineteenth century, when these spaces become, properly, public spaces. In the first place, due to the transfer of ownership to the municipalities, secondly, because, beyond the norms of public decorum, or some racist restrictions such as in South Africa or the USA until well into the 20th century, the spaces will be accessible to 
all citizens, as is already the case in Longchamp or in the Ciutadella Park in Barcelona. The same thing happens with other spaces of the aristocracy that gradually open to the public (Capel 2002). In addition, the design of the space itself, the uses that are developed in it can create invisible barriers- not formal ones- that restrict everyone's access (Goffman 1961, 1963; Hall 1966)

As Cerdà states the city is organized in "Uncovered spaces" and "Empty spaces". The uncovered spaces fall within the sphere of the private and to them belong the "gardens» inside the buildings which should serve as a reserve of light and air, a link between people and nature: «In each house there should be a garden that can be considered as the sphere of fraternal relations of the family with the living forces of Nature "(Cerdà, 1859). On the other hand, for Cerdà empty spaces are those of public use ${ }^{7}$. Empty spaces are those in which the collective life of the city takes place. Cerdà establishes a certain functional division of these spaces in relation to the type of possible uses, setting a typological and functional classification. The first type of space is the "public road», the street, the set of continuous surfaces that Cerdà, as a good neoclassical, understood in relation to the set of built facades, arranged according to the principles of street alignment. With the street there are other types of spaces such as the small squares, the squares, the gardens, the public walks, the parks, the forest.

And the Administration for its part by vanity sometimes, it is necessary to tell the truth completely, and also sometimes obeying a feeling of humanity disputed by hygienists, planted trees and built gardens wherever it found space for it ... ]. Overwhelmed, the citizens due to the concentrated and laborious life that inside the cities are condemned to drag, leave from time to time, as often as possible, to enjoy some leisure time and distraction in the outskirts. For this purpose, cities of some consideration and well managed have walks, parks, gardens, forests, etc.

At certain times of the day, the population flows in large masses to the walks, whose narrowness and lack of scope is then felt and deplored; because they no longer serve those who seek recreation and healthy distraction, but only those who go with the purpose of seeing and being seen. The parks and gardens in the cities that are fortunate to possess them, and even more forests that few of them are allowed to enjoy, are places more on purpose, as well as for hygienic exercises, so convenient for people of sedentary life very numerous in all the big cities, as well as to provide us with innocent fun of the tasks that have occupied us, with eagerness, perhaps, a large part of the day and night. In them they also find pure and life-giving air to breathe the many unfortunate families, condemned to breathe the mephitic and unhealthy of the knives in which they dwell during the entire time they are locked in it.

It is precise to recognize that the Administrations, knowing the great privations that the current urbanization, every day more condensed, imposes without mercy on the inhabitants of the big cities, tries with some dedication to provide these with some compensation, increasing every day the public recreation sites. Private industry, for its part, contributes to these purposes, although with a view to individual interest. Every day you see on the outskirts of large urban centers, stand up special theaters, Champs Elysees ${ }^{8}$ and other various establishments of a similar nature, in which for a

7.- The idea of "Empty space" does not take into consideration the issue of space ownership or only indirectly. Indeed, in its definition, public spaces can be confused with collective spaces.

8.- Cerdà refers both to the "Champs" in París and to those in Barcelona. A recreational park located in the background of the current Paseo de Gracia. Inaugurated in 1885 survived until 1873. Its main attractions were a lake and roller coaster, also having a ballroom and concert hall, which, over time, was transformed into a theater. 


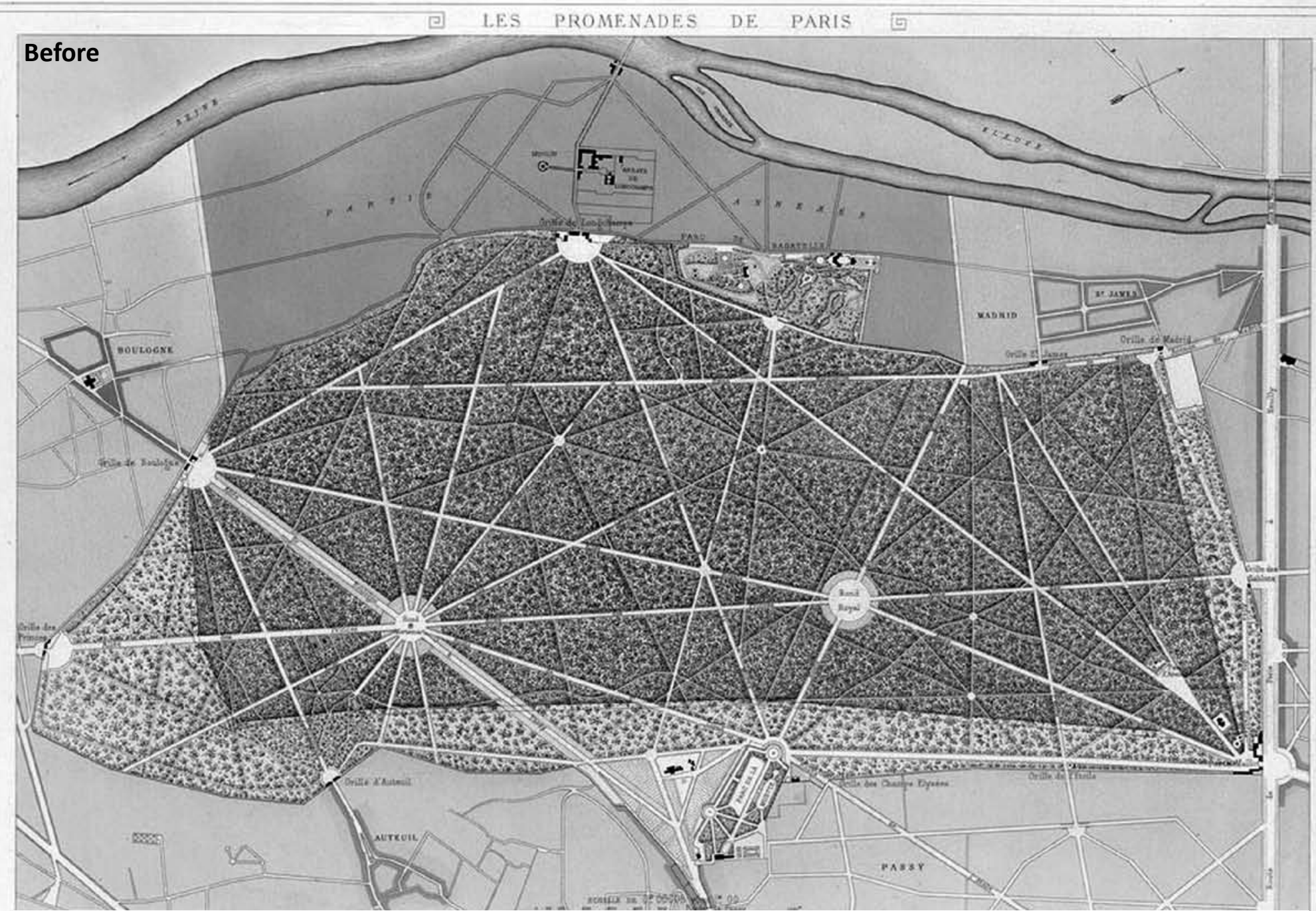

Bois de Boulogne. Before and after the design by Alphand. The straight lines of the paths disappear and are replaced by curved routes. Water goes into the park by almost a third of its surface.
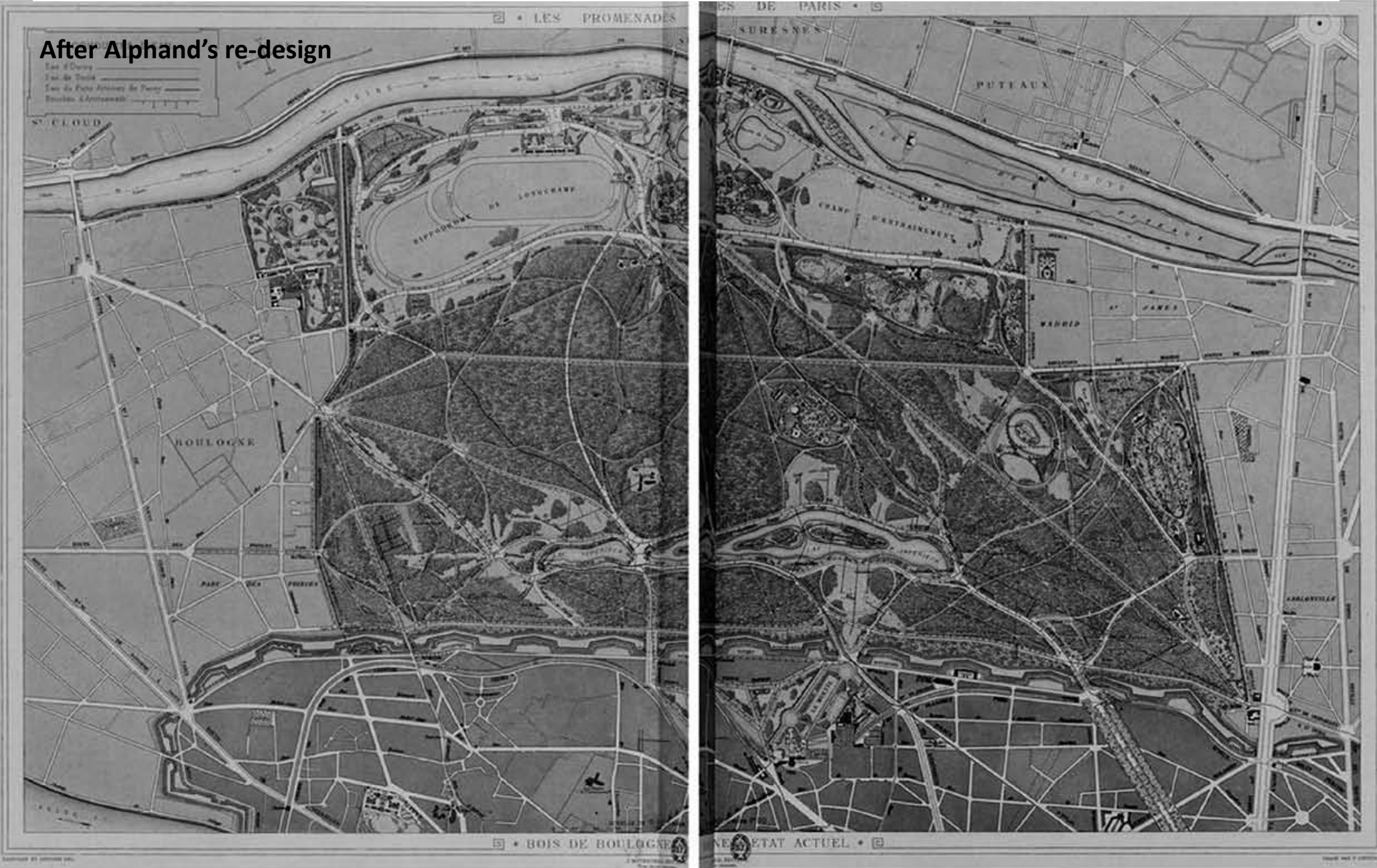
short fee, citizens find entertainment of all kinds. In some countries, attempts have been made to gather instruction with leissure, establishing topographic galleries, panoramas, zoological, botanical collections, etc. at recreational sites. History also has its representation in the statues that decorate (Cerdà, 1867).

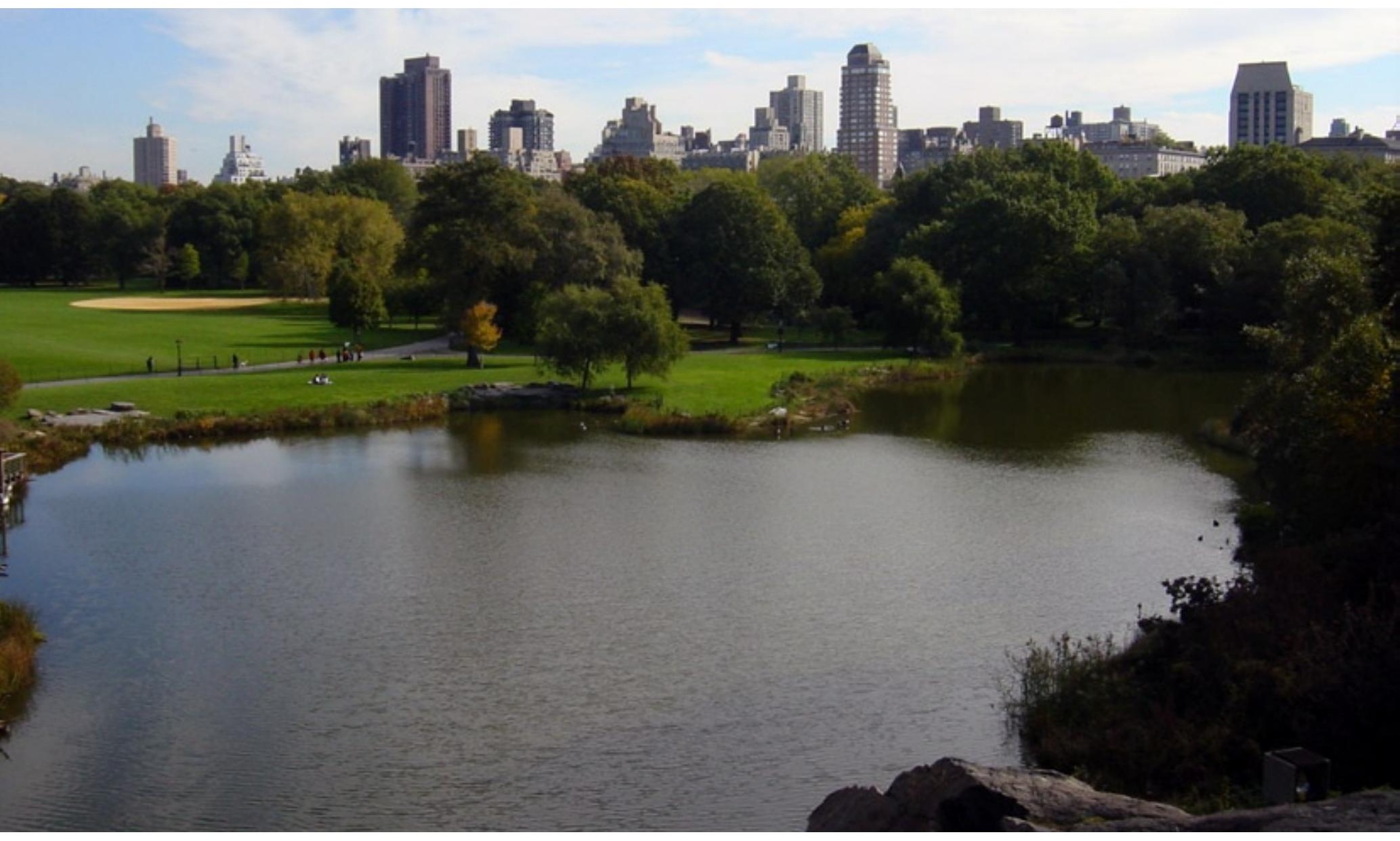

Water as an expression of patrician and reformist democracy

NEW YORK. Central Park was first approved in 1853 as a 315 Ha. park. In 1857, landscape architect Frederick Law Olmsted and architect/landscape designer Calvert Vaux won a design competition to construct the park with a plan they titled the "Greensward Plan".

Construction began the same year, and the park's first areas were opened to the public in late 1858. Additional land at the northern end of Central Park was purchased in 1859, and the park was completed in 1876. After a period of decline in the early 20th century, New York City parks commissioner Robert Moses started a program to clean up Central Park. Another decline in the late 20th century spurred the creation of the Central Park Conservancy in 1980, which refurbished many parts of the park during the 1980s and 1990s. Today the park covers 341 HA and receive almost 38 million visitors per year. 


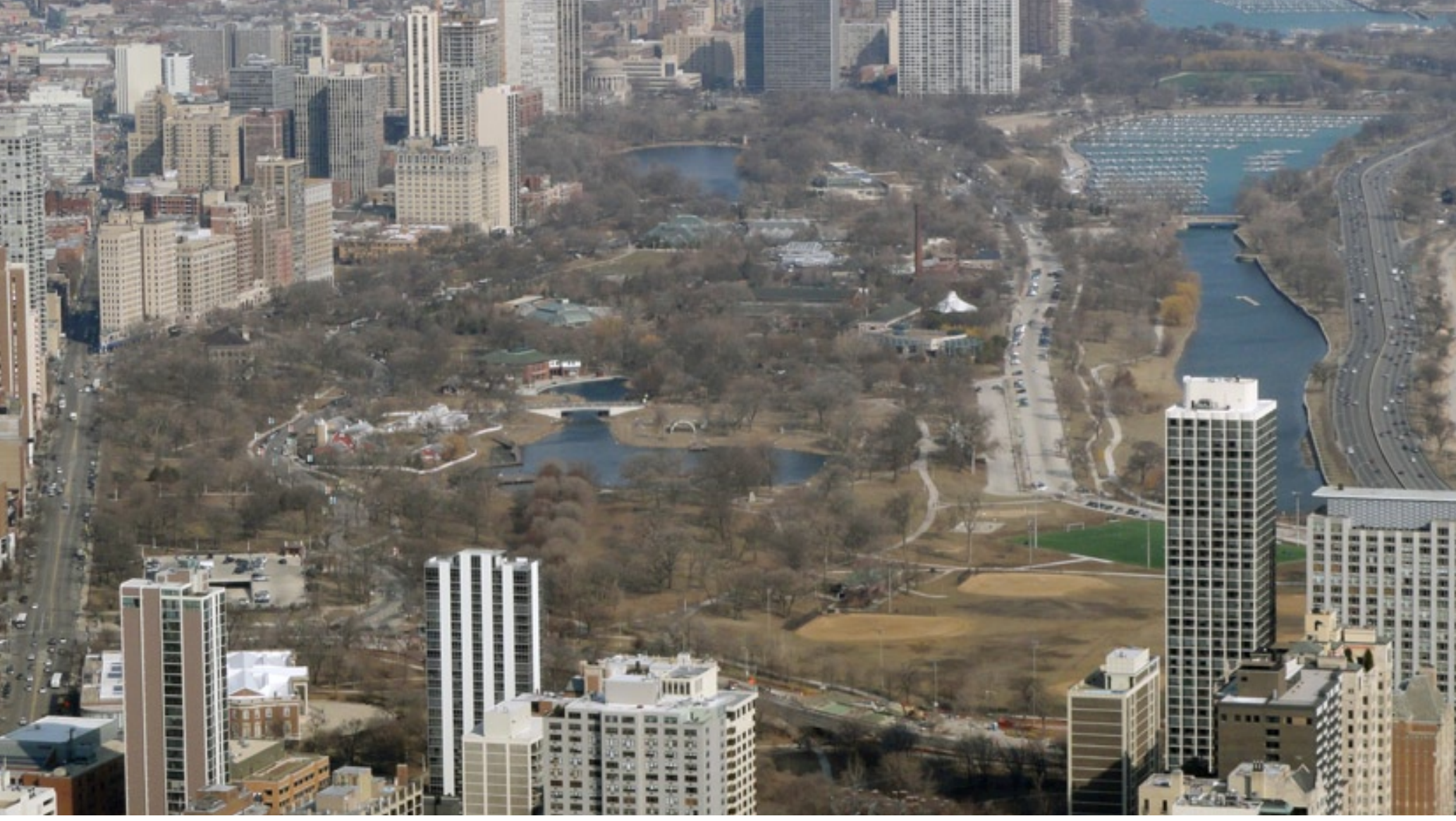

CHICAGO. Lincoln Park is a 489-hectare park situated along Lake Michigan. Named after US President Abraham Lincoln, it is the city's largest public park and stretches for $11 \mathrm{~km}$. In 1860, Lake Park (earlier, Cemetery Park), the precursor of today's park, was established by the city on the lands just to the north of the city's burial ground. Five years later, on June 12, 1865, the park was renamed to honor the recently assassinated President Abraham Lincoln. Lincoln Park is the second-mostvisited city park in the United States, behind Central Park.

Madrid. The Retiro's Lake 
As example. The Retiro's lake in Madrid is an extension of water of artificial origin, with an area of $37240 \mathrm{~m}^{2}$ and a volume of water of $55150 \mathrm{~m}^{3}$. It was created in the first half of the seventeenth century as one of the most relevant landscape elements of the Buen Retiro, a former possession of the Spanish Crown during the reign of Philip IV. The Royal Site had an exclusively courtly use until the last third of the 18th century. In the year 1767 King Carlos III allowed public access to the site, public access to the site, under certain restrictions, and establishes as a limit of visits one of the banks of the big lake. Its ownership corresponds, since 1868, to the Madrid City Council, as well as the landscaped spaces on which the current public park was formed.

With an area of $37240 \mathrm{~m}^{2}$ and a volume of water of $55150 \mathrm{~m}^{3}$, it has a jetty that allows recreational navigation and the celebration of rowing and canoeing competitions. On its banks is the Monument to Alfonso XII. On its banks is the Monument to Alfonso XII. In 1902 a national competition was convened to build a monument to King Alfonso XII. The winner was the architect José Grases Riera with a big project on one of the main sides of the Pond, consisting of a colonnade with a large As example. The Retiro's lake in Madrid is an extension of water of artificial origin, with an area of $37240 \mathrm{~m}^{2}$ and a volume of water of $55150 \mathrm{~m}^{3}$. It was created in the first half of the seventeenth century as one of the most relevant landscape elements of the Buen Retiro, a former possession of the Spanish Crown during the reign of Philip IV. The Royal Site had an exclusively courtly use until the last third of the 18th century. In the year 1767 King Carlos III allowed public access to the site, public access to the site, under certain restrictions, and establishes as a limit of visits one of the banks of the big lake. Its ownership corresponds, since 1868, to the Madrid City Council, as well as the landscaped spaces on which the current public park was formed.

With an area of $37240 \mathrm{~m}^{2}$ and a volume of water of $55150 \mathrm{~m}^{3}$, it has a jetty that allows recreational navigation and the celebration of rowing and canoeing competitions. On its banks is the Monument to Alfonso XII. On its banks is the Monument to Alfonso XII. In 1902 a national competition was convened to build a monument to King Alfonso XII. The winner was the architect José Grases Riera with a big project on one of the main sides of the Pond, consisting of a colonnade with a large number of sculptures surrounding the equestrian statue of the king, next to the lake, in bronze and marble. When José Grases died he was replaced in the direction of the works by Teodoro Anasagasti, who did not introduce modifications. The monument, financed by popular subscription, was unveiled on July 22, 1922. The whole set is 30 meters high, 86 meters wide and 58 meters deep, and more than twenty sculptors participated in its elaboration, among which Mariano Benlliure, Josep Clarà and Mateo Inurria stand out. 


\section{Monumental waterfalls.}

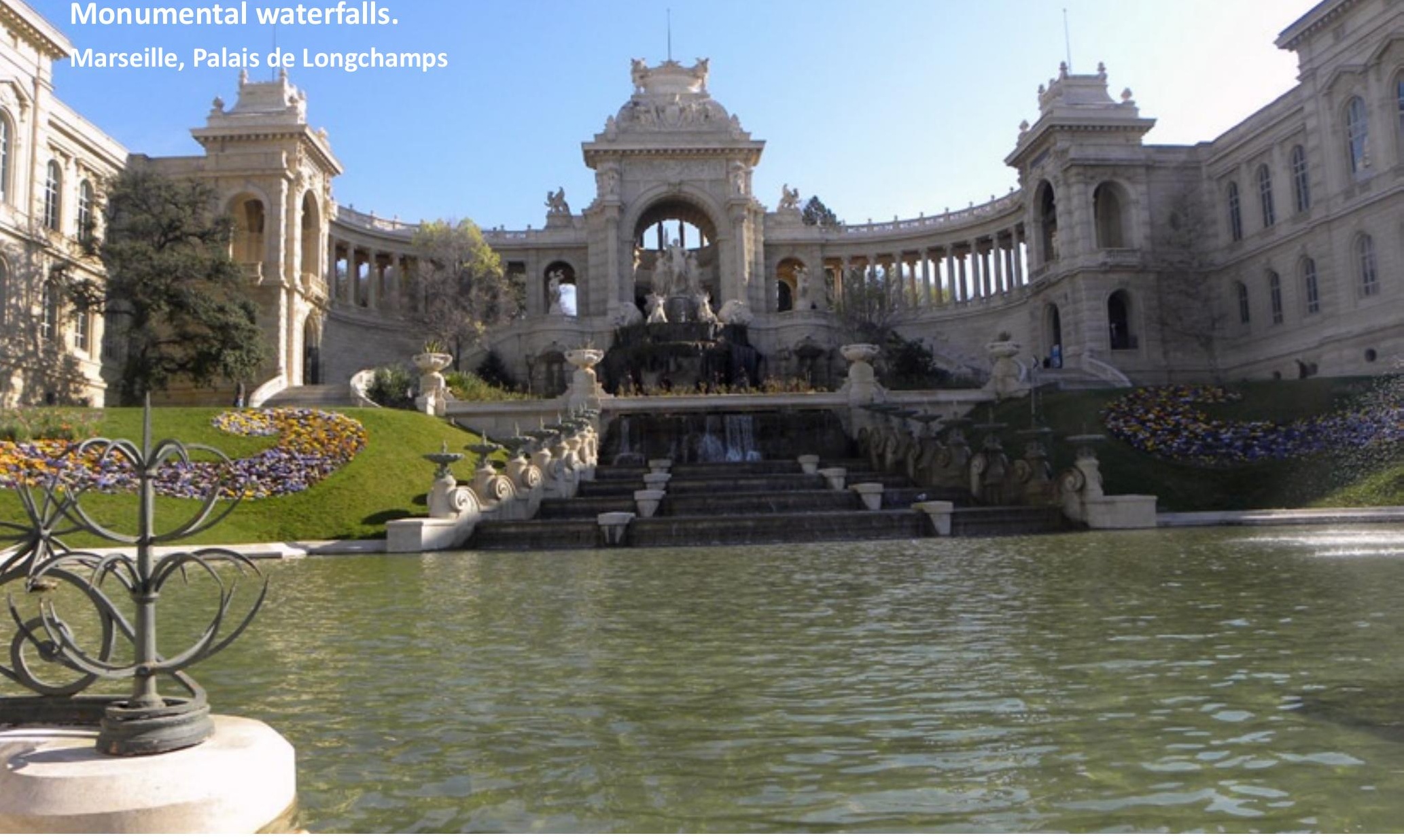

In 1849 the waters of the Durance River arrive in Marseille, following the channel traced by Frantz Major de Montricher that must reach a large water tower located in the middle of a new park, the Longchamp Park, the Observatory and the Marseille Zoo are installed

At the beginning of 1859, the mayor of Marseille, Jean-François Honnorat, asked the sculptor Auguste Bartholdi to carry out a water tower project. Bartholdi first thought only of a monumental fountain. After several interviews with the municipal council, he associated a museum divided into two isolated bodies with a central water tower.

It presents a third project by connecting the buildings by a vast gallery having its entrance in the axis of the monument. Faced with the hesitation of several of its members, the municipal council turned to judge this project by a commission made up of specialists: Henri Labrouste and Léon Vaudoyer, general inspectors of diocesan buildings, and Victor Baltard, architect of the city of Paris. This commission criticizes the project which will not be selected.

In 1862, the architect Henry Espérandieu conceived an ambitious project to celebrate the event. He converts the great water tower in a palace to the glory of water in a garden setting. The entrance to the Palais Longchamp is through two gates placed symmetrically with respect to the general axis of the building. Each entrance portal is framed by high pedestals on which are erected statues sculpted by Antoine-Louis Barye depicting a wild beast devouring its prey.

The aisles on which the two gates open follow the curves of the pool to reach the main staircase. This staircase which encloses the reception basin of the waterfall is interrupted on a terrace to give access on the left to the Museum of Fine Arts and on the right to the Museum of Natural History.

The triumphal arch, open on all sides, has a sumptuous entablature surmounted by a dome. The front side of this dome is decorated with a trireme from which the city's arms stand out, framed by two sirens. The whole was sculpted by Eugène-Louis Lequesne.

The central group is, with its ten meters in height, an imposing work by Jules Cavelier. Made of 


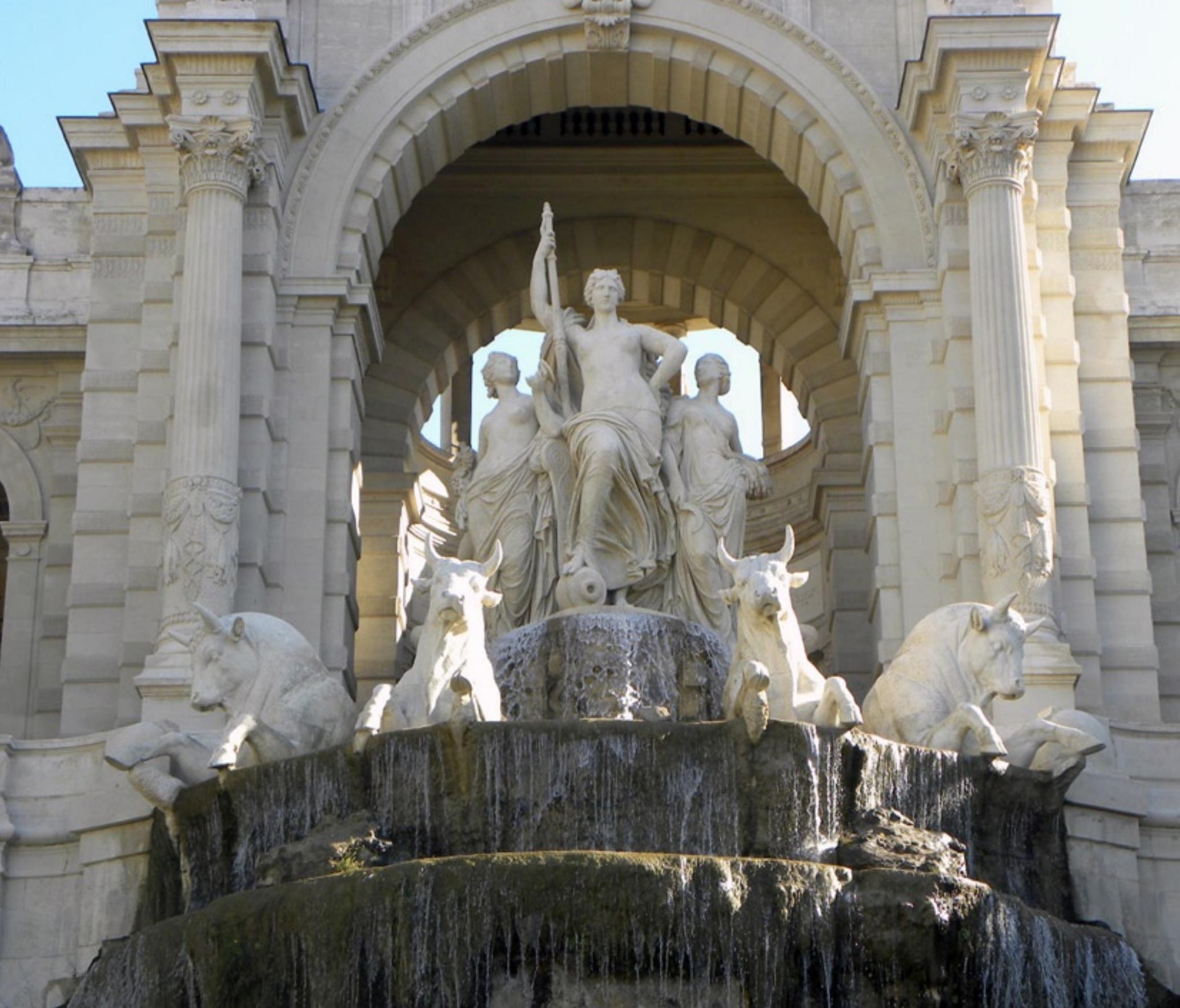

Calissanne stone, it represents a chariot emerging from the water tower, drawn by four Camargue bulls that seem to be heading towards the city.

On this chariot are represented three female allegorical characters. The figure of the Durance, proudly camped in the centre, is draped in an ancient peplum.

In Barcelona, a similar project was developed at the Parc de la Ciutadella. The park is in the site of a large military citadel built in 1715 to control the city, following its surrender on 11 September 1714 , in the previous land of the Ribera's neighbourhood.

In 1869, General Prim handed the citadel over to Barcelona. His condition was that the land should be used as a public park. The military fortress was then pulled down by groups of volunteers.

The reclaiming of this land meant a much-needed large green space could be created in a Barcelona that was becoming increasingly overcrowded. Places were needed to "allow breathing", as Joseph Fontseré expressed in his project's slogan: "Gardens in cities serve the same purpose as lungs in the human body". (Arranz et al., 1984; Torres iet al., 1985)

The original layout was amended to include the Universal Exposition of 1888 and, later on, to accommodate the Zoo, one of the most important in Europe, which occupies half of the land. 


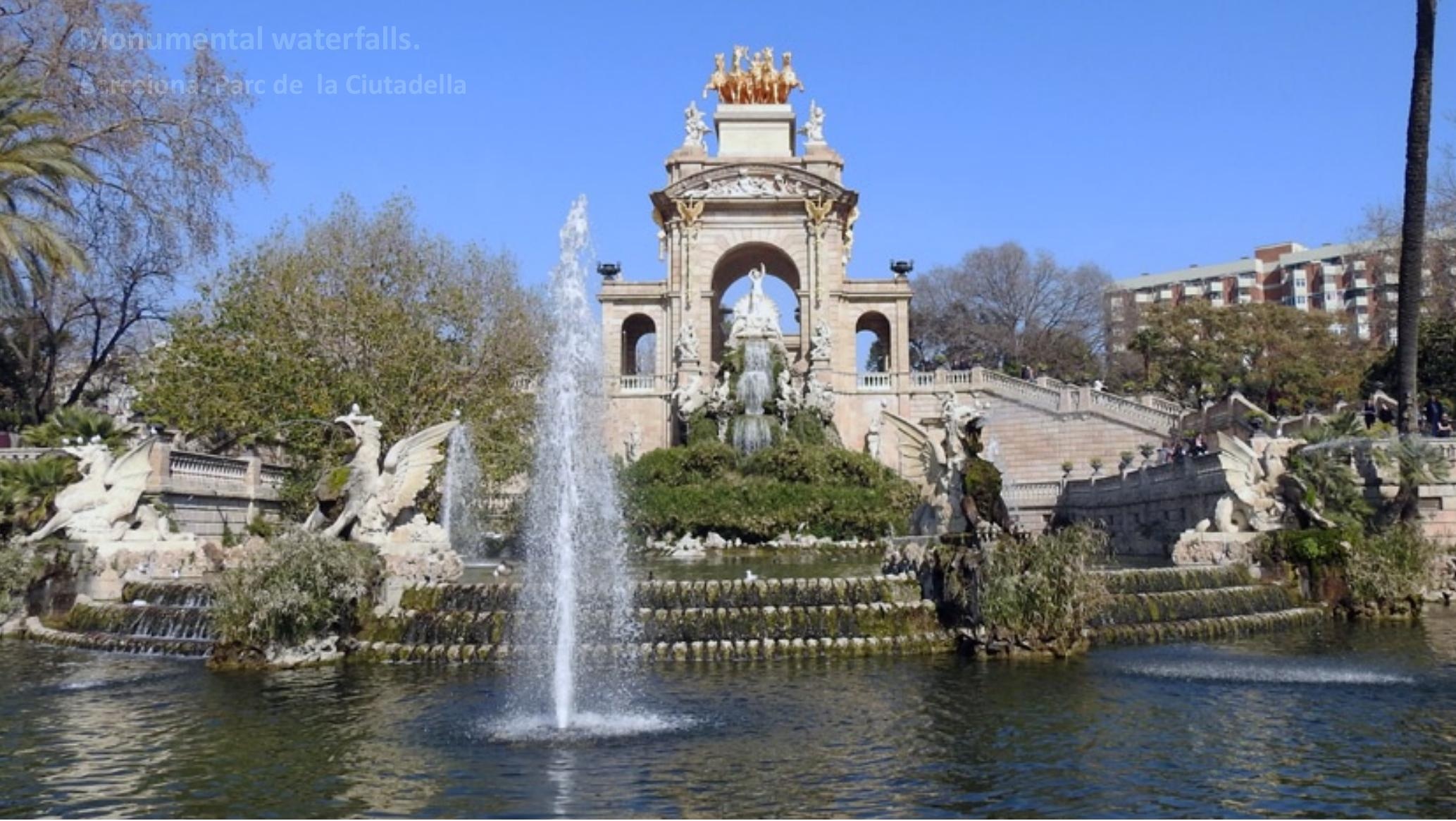

Inspired in the Longchamps Palace,the monumental waterfall was designed by Josep Fontserè in 1875 and officially opened in 1881 . Fontserè had a very young Gaudí as his assistant, to whom the rocky decoration of the waterfall and some of the decorative motifs have been attributed.

The waterfall is decorated with numerous sculptural features by Catalan artists from the end of the 19th century and put together after its official opening. The central element is Venanci Vallmitjana's Birth of Venus; and the highlight of these works, at the top, is the Aurora's Chariot] by Rossend Nobas, who also sculpted four groups of jinns, two fauns and the figure of Eros. Four griffins beneath, modelled by Rafael Atché, protect the Venus. There are steps from one end to the other giving access to a type of temple for contemplating the park from a privileged perspective.

Near from the waterfall it is an artificial lake

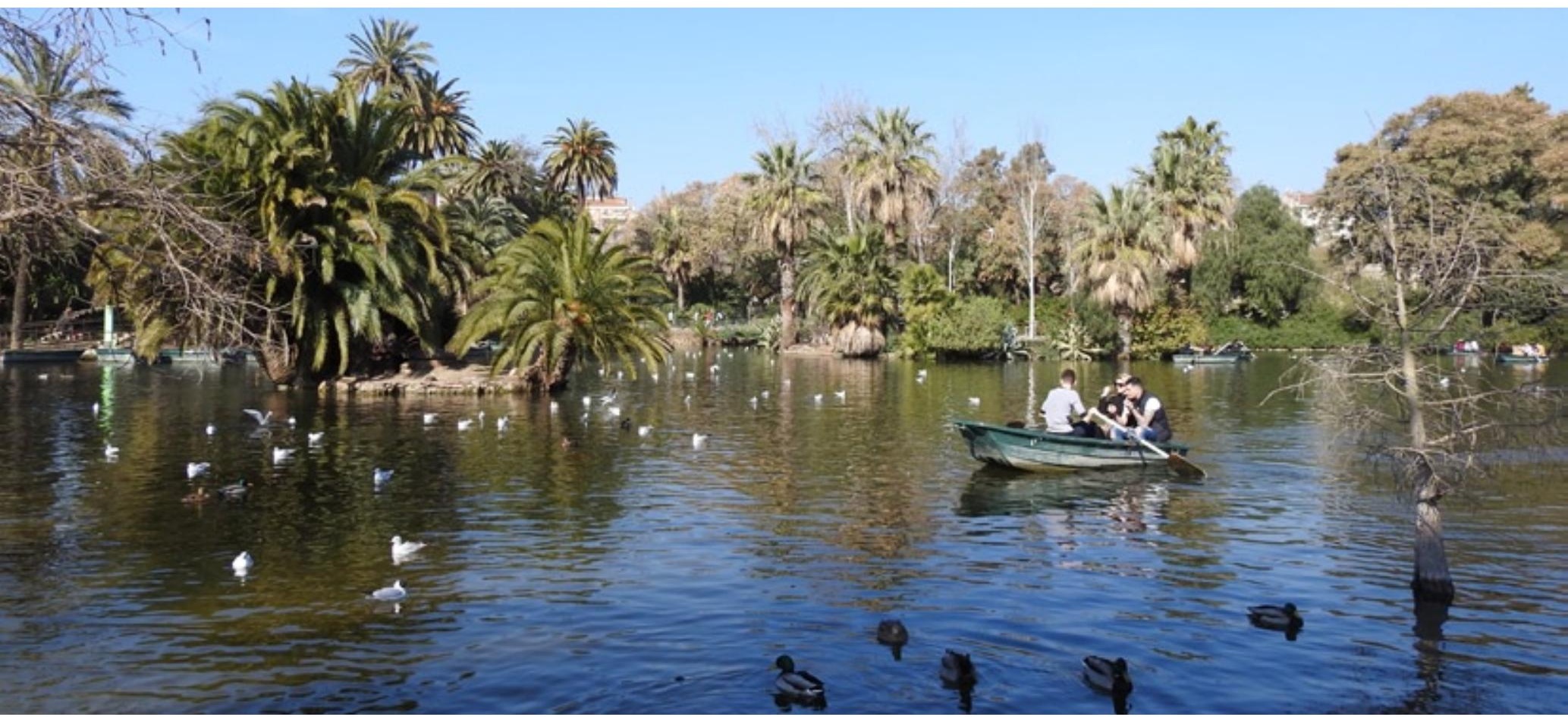


A.bastecimiento de aquas para los Parques y jardines de la ex-Liudadela.
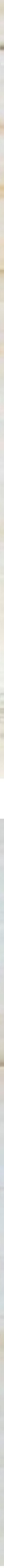


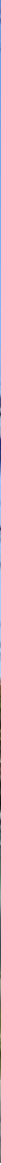

eration and well managed have walks, parks, gardens, forests, etc.

At certain times of the day, the population flows in large masses to the walks, whose narrowness and lack of scope is then felt and deplored; because they no longer serve those who seek recreation and healthy distraction, but only those who go with the purpose of seeing and being seen. The parks and gardens in the cities that are fortunate to possess them, and even more forests that few of them are allowed to enjoy, are places more on purpose, as well as for hygienic exercises, so convenient for people of sedentary life very numerous in all the big cities, as well as to provide us with innocent fun of the tasks that have occupied us, with eagerness, perhaps, a large part of the day and night. In them they also find pure and life-giving air to breathe the many unfortunate families, condemned to breathe the mephitic and unhealthy of the knives in which they dwell during the entire time they are locked in it.

It is precise to recognize that the Administrations, knowing the great privations that the current urbanization, every day more condensed, imposes without mercy on the inhabitants of the big cities, tries with some dedication to provide these with some compensation, increasing every day the public recreation sites. Private industry, for its part, contributes to these purposes, although with a view to individual interest. Every day you see on the outskirts of large urban centers, stand up special theaters, Champs Elysees ${ }^{8}$ and other various establishments of a similar nature, in which for a short fee, citizens find entertainment of all kinds.

In some countries, attempts have been made to gather instruction with leissure, establishing topographic galleries, panoramas, zoological, botanical collections, etc. at recreational sites. History also has its representation in the statues that decorate some gardens, when it is not a lighter idea that has presided over such decorations (Cerdà, 1867).

The hygienist thought is widely spread throughout the world (Haddad, Marie, 2017b) and the 8.- Cerdà refers both to the "Champs" in París and to those in Barcelona. A recreational park located in the background of the current Paseo de Gracia. Inaugurated in 1885 survived until 1873. Its main attractions were a lake and roller coaster, also having a ballroom and concert hall, which, over time, was transformed into a theater. 
Monumental waterfalls.

Havana. The Vedado's Slope waterfall
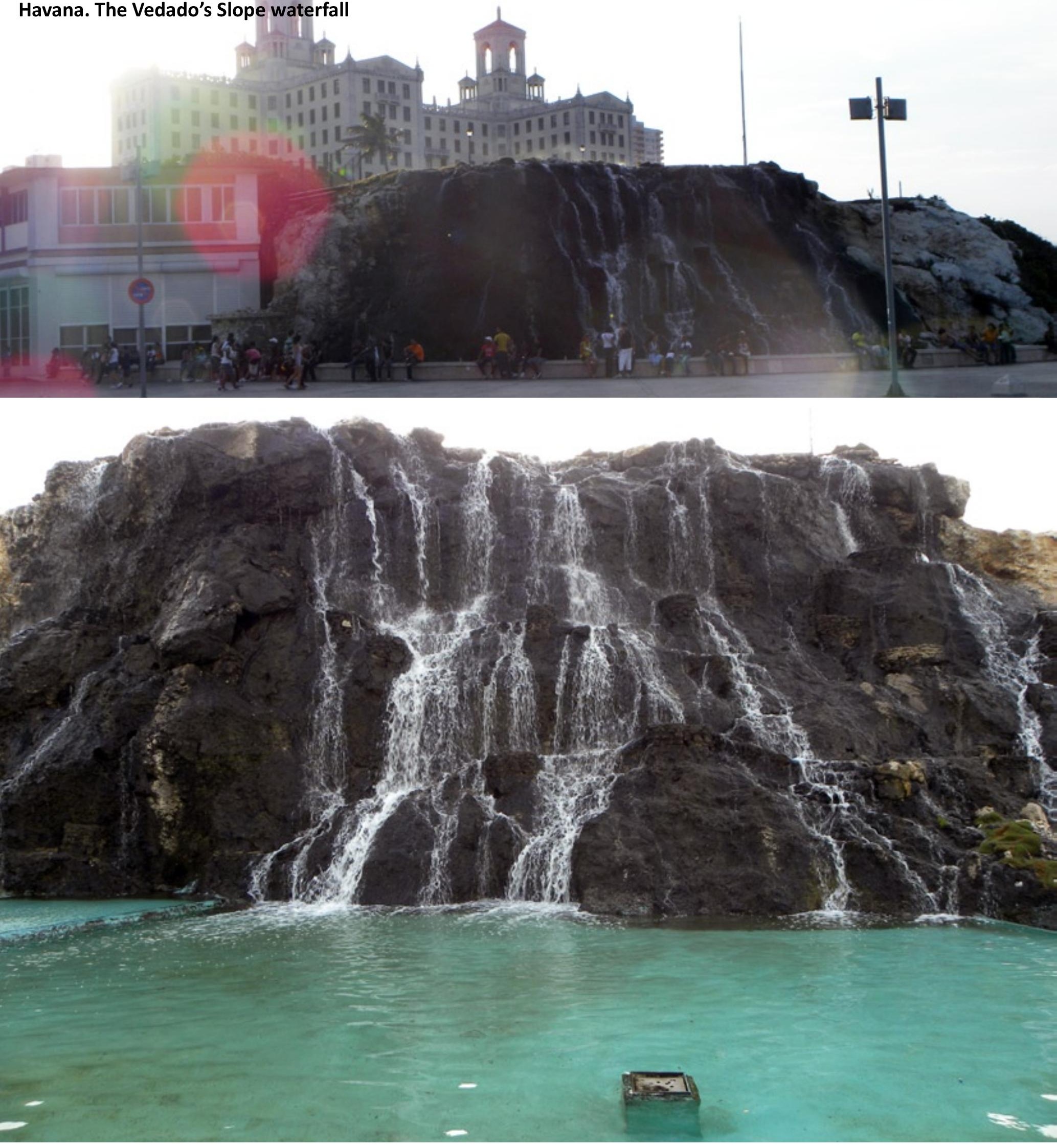

The National Hotel is located at a higher level than the Malecon promenade. The hotel gardens extend to the Malecon limit. To solve the slope while preserving the privacy of the gardens, an artificial waterfall was built just at the corner of the intersection between 23rd Avenue or Vedado's Slope and the Malecon.

We have no exact knowledge of who designed the waterfall, but it could have been the teams of the McKim, Mead \& White and Purdy \& Henderson Co companies, in charge of the plans and the execution of the National Hotel project. 

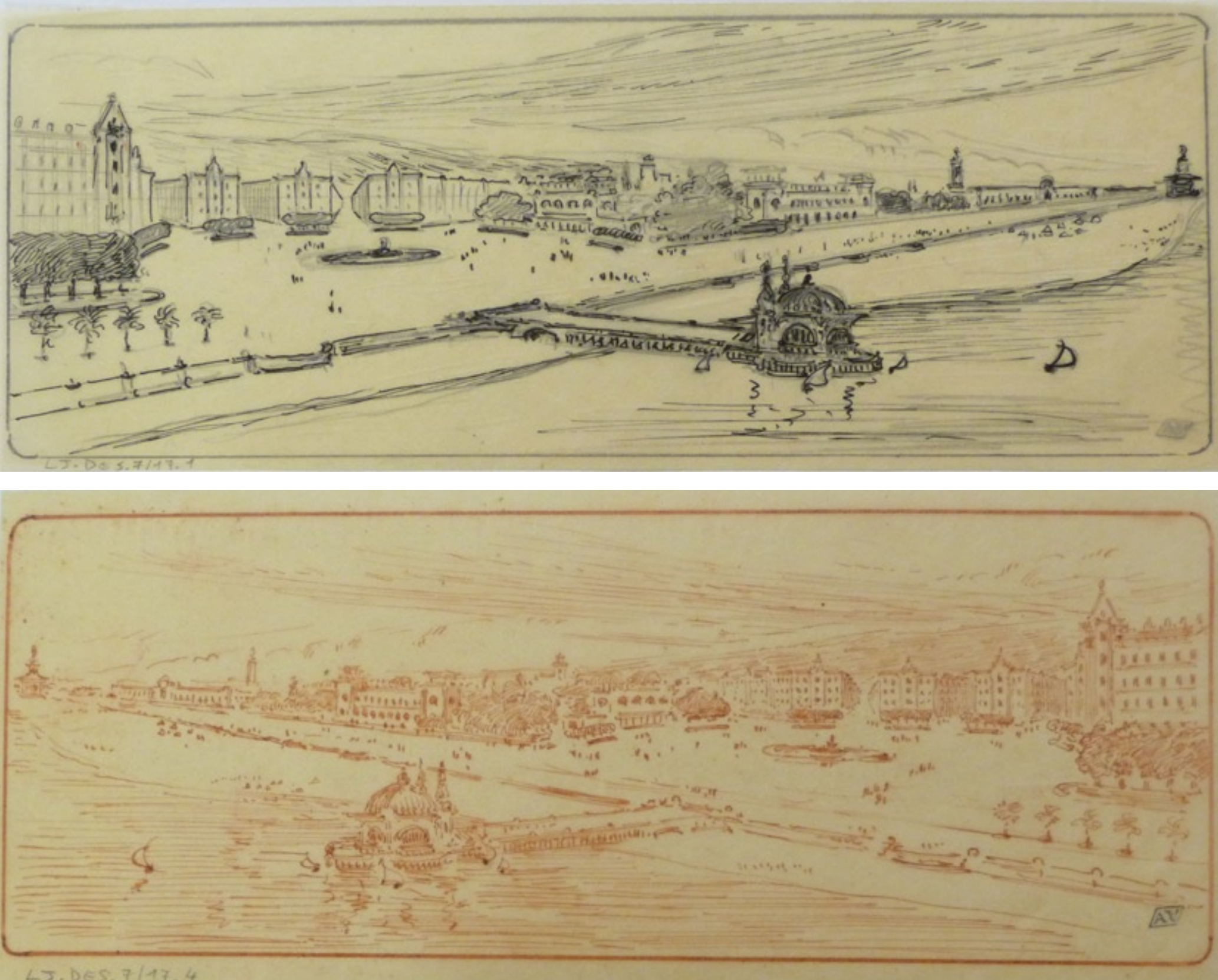

Jaussely. Drawings of the proposal for a promenade for BarceIona (c. 1907). Source: cite de l'architecture et du patrimoine archives ifa $\backslash 01$ fonds Jaussely

zation works we can highlight a peculiar white banister, that covers the whole promenade.

On the same dates, the idea to build a "costanera" along the Rio de La Plata (Buenos Aires) shores was developed between 1916 and 1919, with a project by the agronomist and landscape engineer Benito Javier Carrasco. Between 1918 and 1950, the Municipal Baths worked on the South "costanera". It now stands as a promenade framed by the Ecological Reserve and included in the new neighborhood of "Puerto Madero" urban regeneration operation of the 1980's (Berjman, Sonia, 1990, 1998; Martire, Agustina, 2008a).

9.- The increase in commercial traffic in Buenos Aires required the construction of a new port in the city. Eduardo Madero had presented several projects for the construction of a new port in 1861 and 1869, but it was in 1882 when his project was accepted thanks to his uncle Francisco Madero, vice president of Argentina. The project, funded by Baring Brothers, had a system of four closed docks linked together, and a north and south dock that facilitated the arrival of ships. The port was inaugurated in 1884, but the north dock and dike 4 were inaugurated only in 1897. The port had many deficiencies, so in 1908 the National Congress decreed the construction of the New Port, in charge of the company CH Walker \& Co. The works began in 1911, and was provisionally inaugurated in 1919. It is made up of open docks and is located north of Córdoba Avenue. 


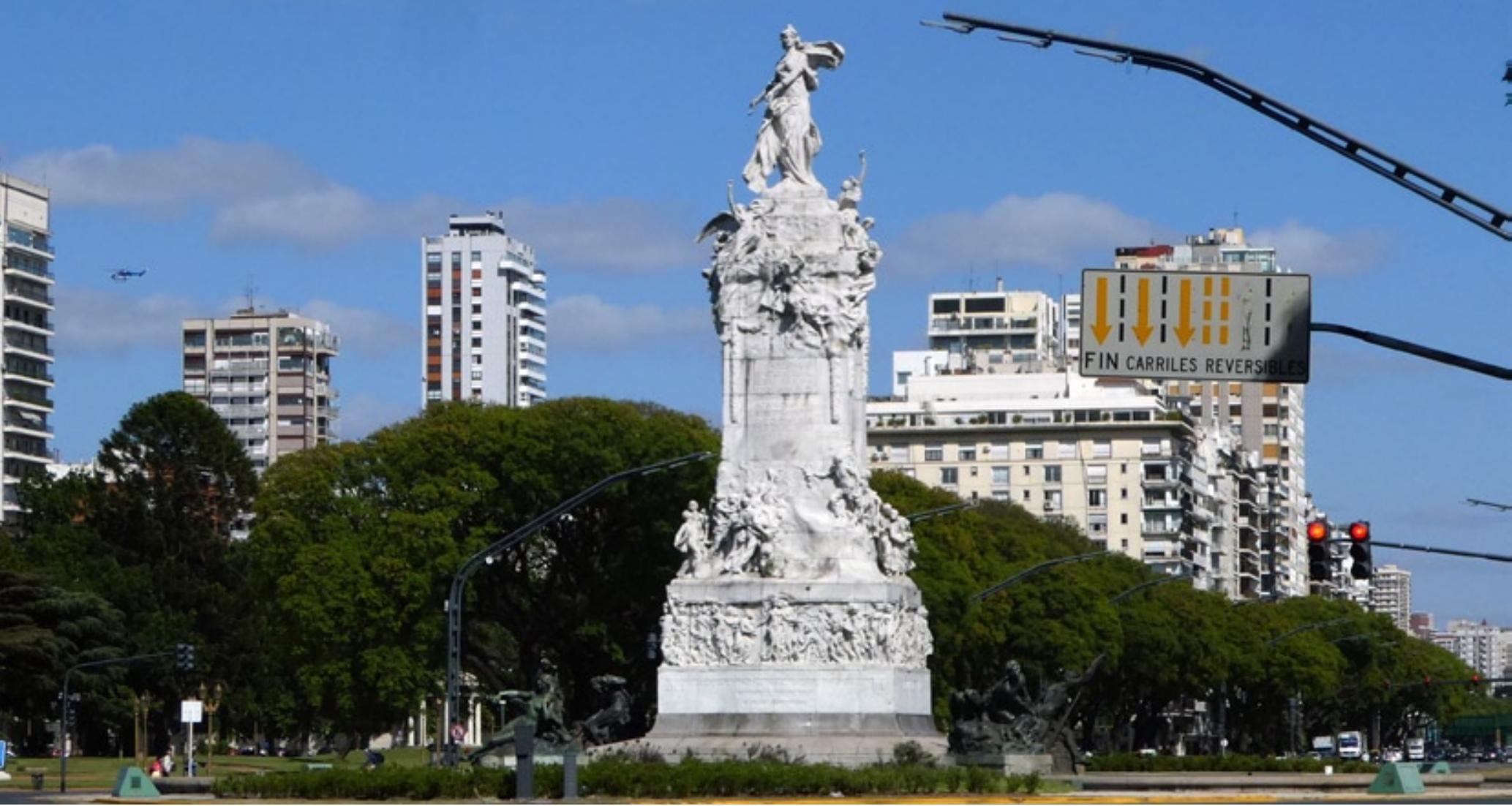

Japanese Garden, the Buenos Aires Zoo and the Buenos Aires Botanical Garden are part of this extensive park.

Among the many monuments, they draw attention: the first and only sculpture not serialized by Rodin outside France, the Sarmiento Monument (1899-1900); the Monument to the Magna Carta and the Four Argentine Regions popularly known as the Monument of the Spaniards since it was donated by the Spanish community in 1910 on the occasion of the centenary of the May Revolution, by Agustín Querol. Although the inauguration stone was laid in 1910, various inconveniences delayed the completion of the work, which was finally inaugurated in 1927.

Recently, 2014, the National Monument to the Memory of the Victims of the Holocaust, by the architects Gustavo Nielsen and Sebastián Marsiglia, has been installed. The Argentine Government ordered its realization, in the year 2000, in homage to the memory of the victims of the Jewish holocaust and the Legislature of the Autonomous City of Buenos Aires authorized its location. It consists of a wall approximately 40 meters long by 4 meters high and one deep, consisting of 114 pre-molded concrete parallelepipeds, representing the victims of the attack on the Israeli embassy in Argentina and the victims of the AMIA attack. In each block a print of an everyday object is stamped.

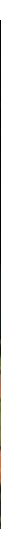




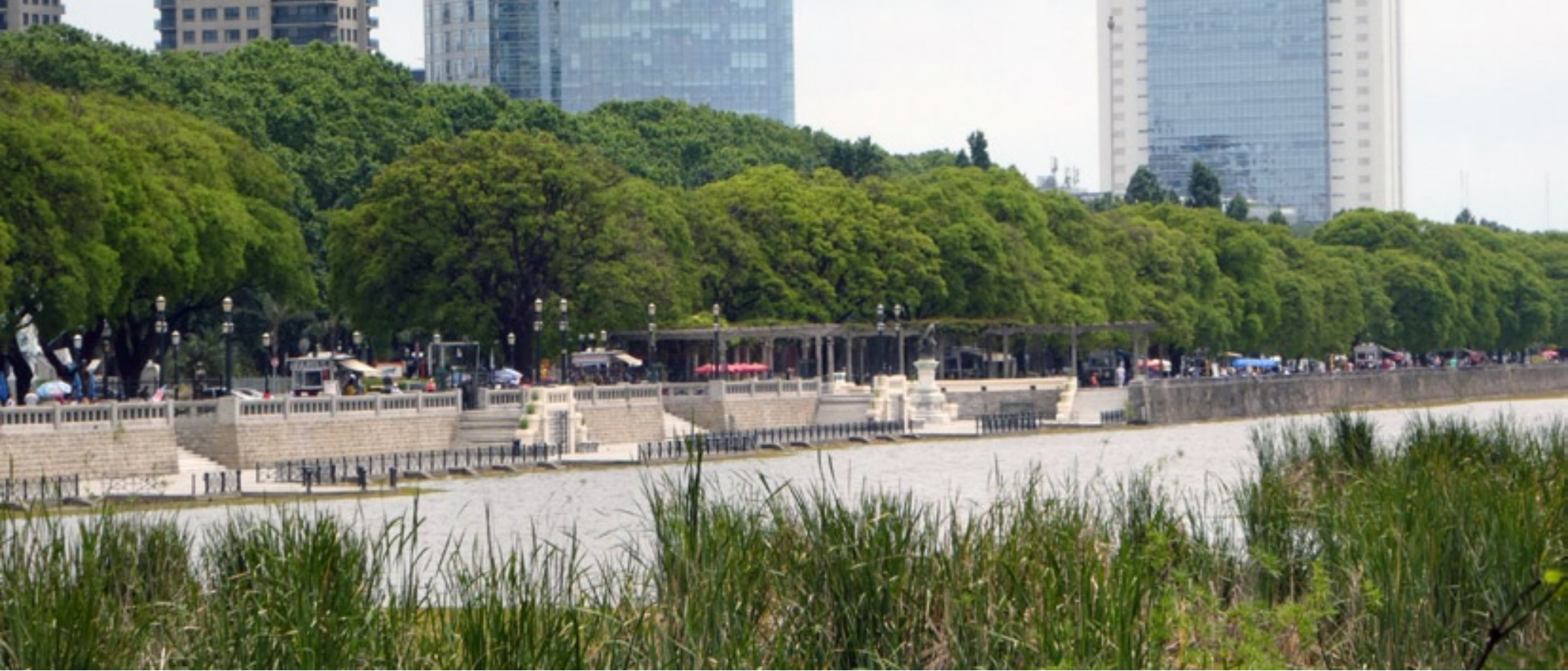

As we have already pointed out, the use of water as an element of the urban landscape, involves not only the creation of water spaces, but also the recovery of the "water fronts". In Buenos Aires, the project to build a costanera for the shores of the La Plata river, was developed between 1916 and 1919. It was the work by the agronomist and landscape engineer Benito Javier Carrasco. Between 1918 and 1950, the Municipal Baths worked on the South Costanera. It now stands as a promenade framed by the Ecological Reserve and included in the new district of "Puerto Madero" urban regeneration operation of the 1980's and 1990's.

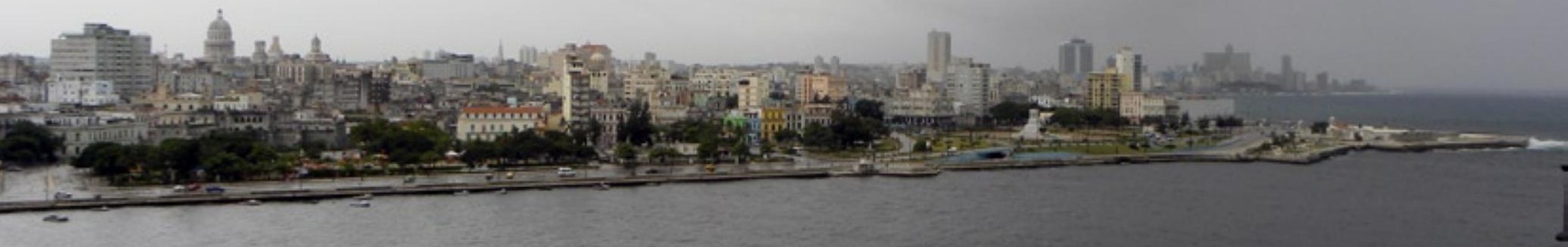


The change in social habits throughout the nineteenth century opened the use and enjoyment of the sea to citizens. Baths, water sports, simple contemplation of the landscape, enhancement of that other half of the city that is the sea in the port cities and the spine of the city that is the river in the river cities.

No less disturbing for the urban planner must be the concern of promoting and protecting the network of free surfaces, both those that are inside the city in the form of gardens, squares of adornment and other provisions, such as those that surround it, be they forests, meadows or other green surfaces, which, together with the water of the lakes, ponds or streams, contribute not only to the beautification of the place, but to the sanitation of the city (Porcel, Llopart and Rubió, 1927).

It is not surprising that the French urban planners of the late nineteenth and first third of the twentieth century [those associated with the Social Museum and the "Art Public" movement) highlighted the idea of organizing the urban layout based on a park system and walks that will guarantee access to water.

In order to understand what a park system is, it is necessary to define and classify the various elements which can be listed: large reserves and protected landscapes; suburban parks; large urban parks; small parks; neighborhood gardens; playgrounds which may also include kindergartens; avenues-promenades [...]. Promenade avenues, American parkways, Promenades in Austria, the Ring of Cologne, the Anlage of Frankfurt are not the least essential parts of the program.

They are intended to serve at the same time as means of communication in the city, of pleasant and convenient access to its parks, to its large reserves, to its countryside, of liesson also to the whole. They will ensure for the future, sometimes even for the moment, a sufficient and complete system of convenient, wide and beautiful exits from the city.

The parkway, the avenue-promenade, is not, strictly speaking, a boulevard. In America, however, it sometimes happens that the two words are sometimes taken for each other (Forestier, J.C.N, 1906)

In Havana, Forestier (1928) will design the "malecón" and creates the system of avenues and parks on the entrance of the Havana port (Duverger, 1990; Gómez Días, 2008). Forestier himself (1914) will project the system of parks that open to the Bu Regreg River and the Atlantic Ocean in Rabat, as well as the Aguedal gardens. The promenades, following the terminology of the Promenade des Anglais in Nice, "paseos marítimos", "malecones" or "costaneras" in some IberoAmerican countries, will constitute one of the urban design resources in vogue in the first third of the 20th century. Forestier, as we have mentioned, will participate in the design of contact with water in several cities and especially in Buenos Aires even though his project was not carried out.

This avenue will be built on the new land conquered on the river, taking advantage of the embankments from the excavation of the canal and part of the new port to follow the bank of the river. The project includes only the part that belongs to the municipality of Buenos Aires. The avenue has been traced at its end so that it can be extended in the direction of the Tigris, and at the same time that it can fork at the end of the city to access the large ring road (Forestier, 1924).

The interest in opening the city to its water front will result in a multitude of interventions in vari- 


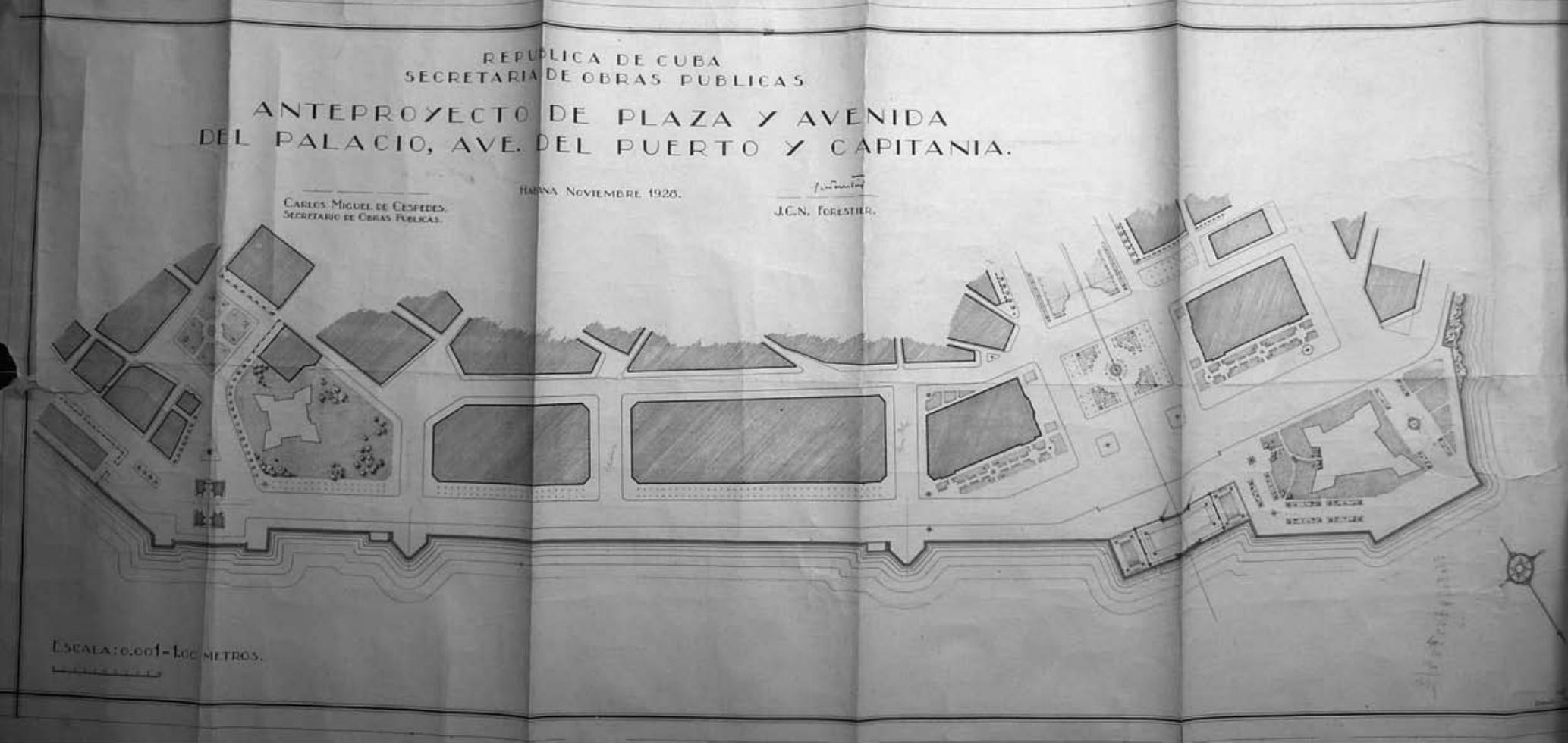

Forestier . 1928-1929. Aménagements autour du palais et du port, La Havane. Source : cite de l'architecture et du patrimoine archives ifa. Fons Forestier

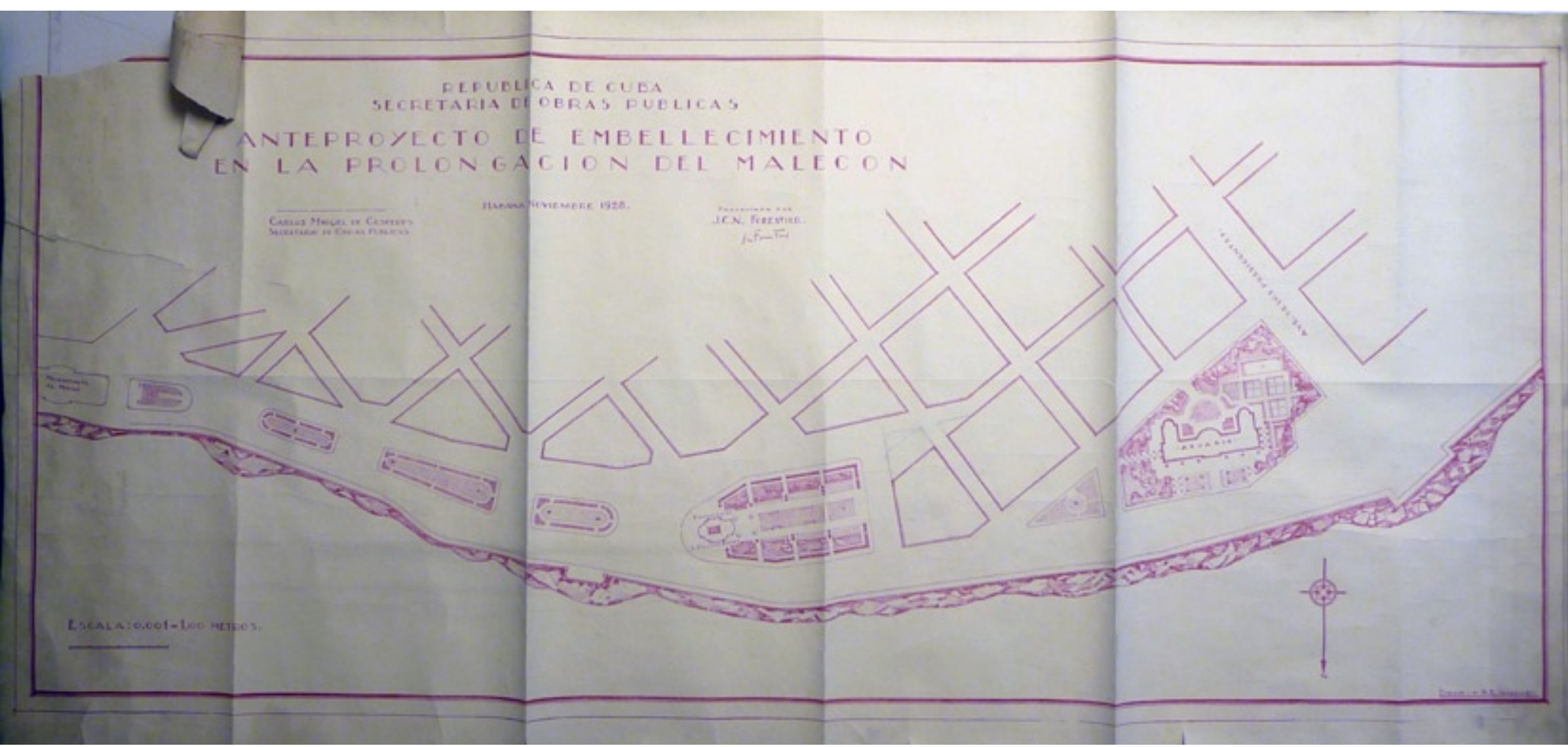

Forestier. 1928 embellissement et prolongation du Malecon, La Havane plan de l'avant projet, nov. 1928. Source : cite de l'architecture et du patrimoine archives ifa. Fons Forestier

ous cities. Thus, in the wake of the Promenade des Anglais, in Beirut, in the 1920s, the Promenade des Français or Corniche is planned and built (Hindi, 2015). The dictator Salazar will locate the Portuguese World Exhibition of 1940 in the Belém riverside area, combining a first articulation of a riverside promenade with the park system that takes Montsanto as the green heart of Lisbon (Costa, 2007; Elias, 2007; Ochoa, 2011). Barcelona, like other Spanish cities, will develop the first layout of its Promenade at the end of the 1940s.

This Malecon in Havana contains several curiosities. Forestier had worked on the site projects for 


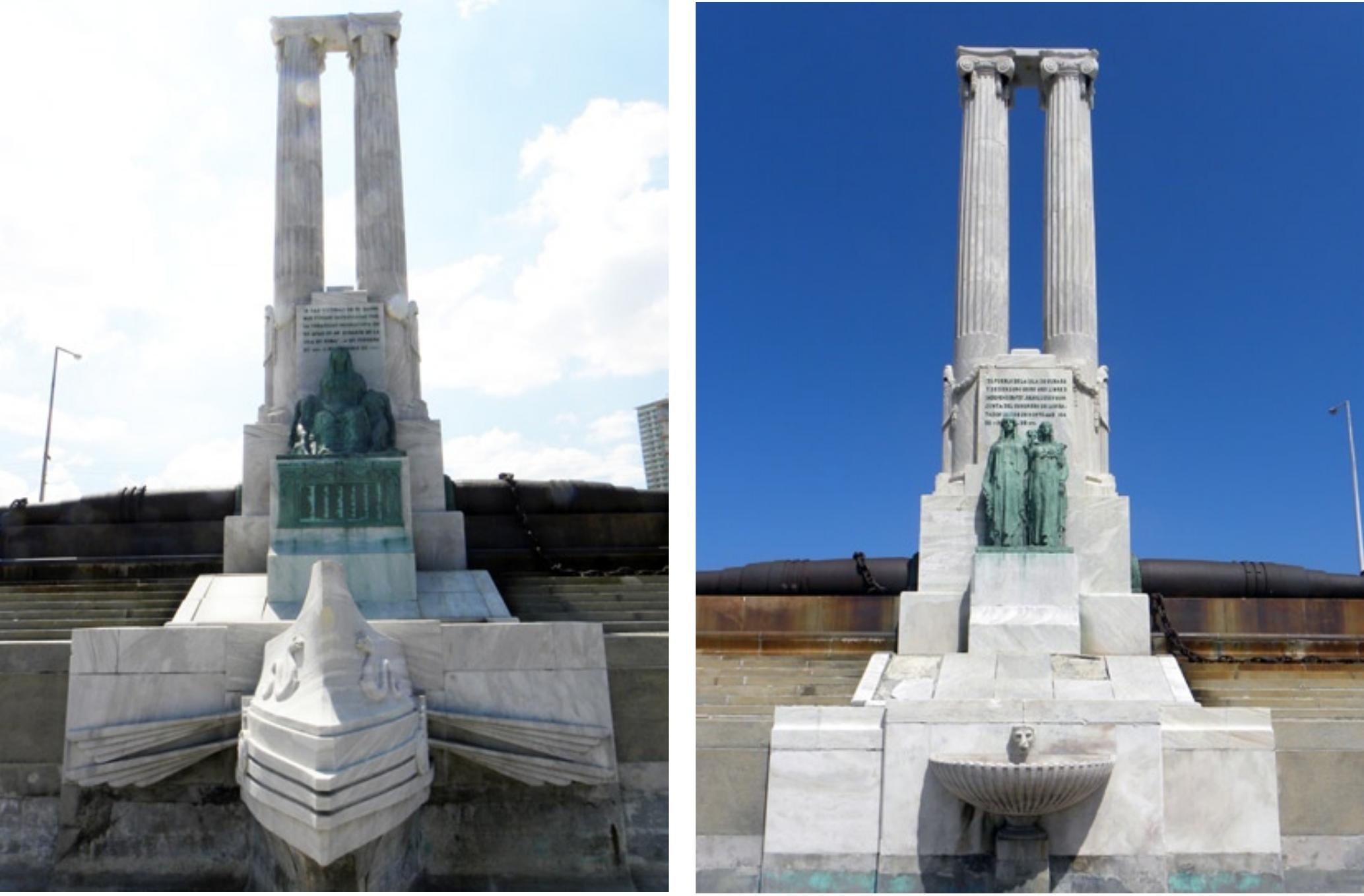

Monument to the victims of Maine. Félix Cabarrocas (eng) and Moisés de Huerta (sculp). 1925. On January 18, 1961, the Board of Monuments, created by the Cuban revolutionary government, agreed to modify the monument and as a result the eagle, busts were suppressed and other changes were made such as the placement of a card with the following inscription: "To the victims of El Maine who were sacrificed by the imperialist voracity in their eagerness to seize the island of Cuba. February 1898-February 1961

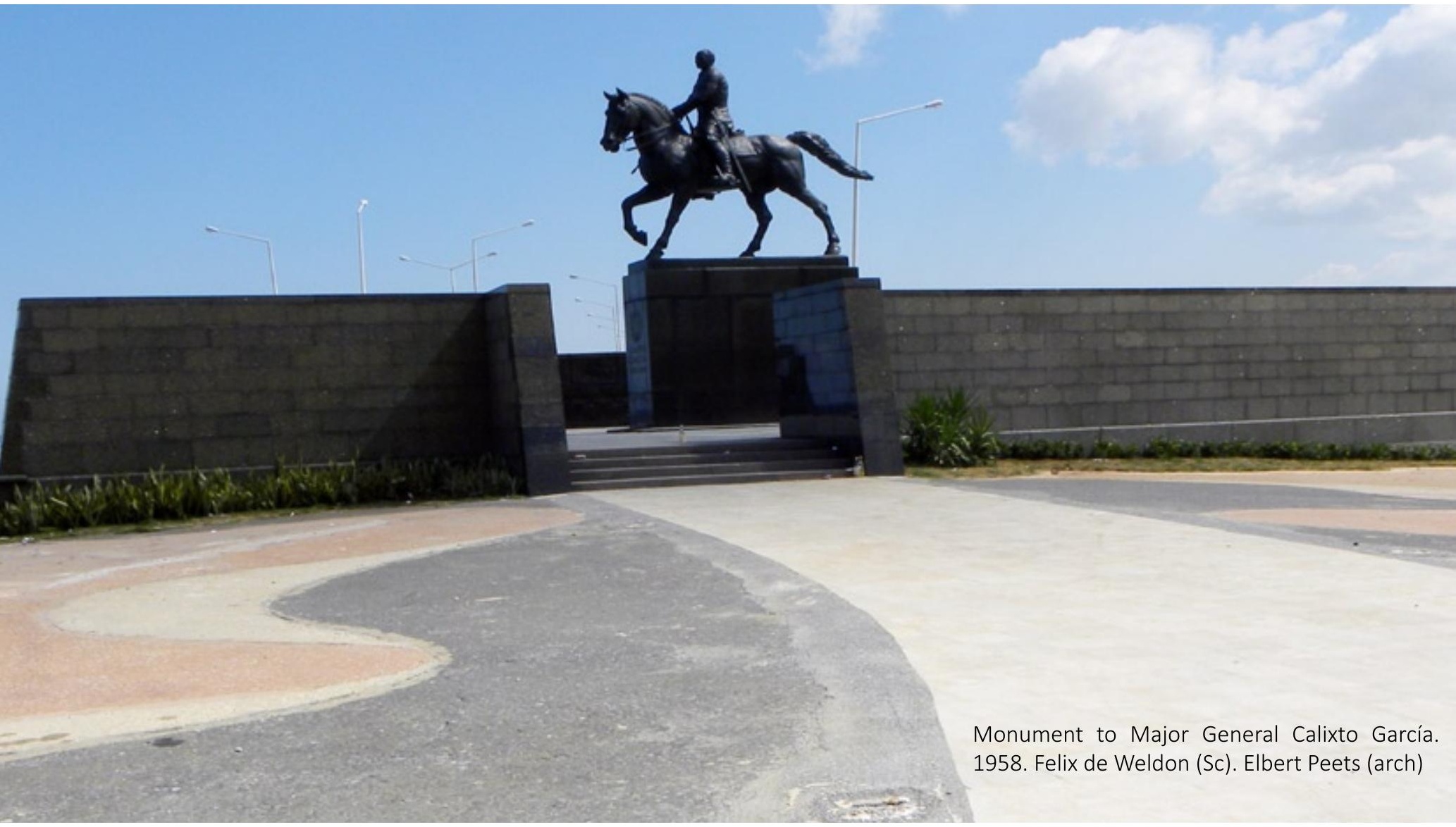




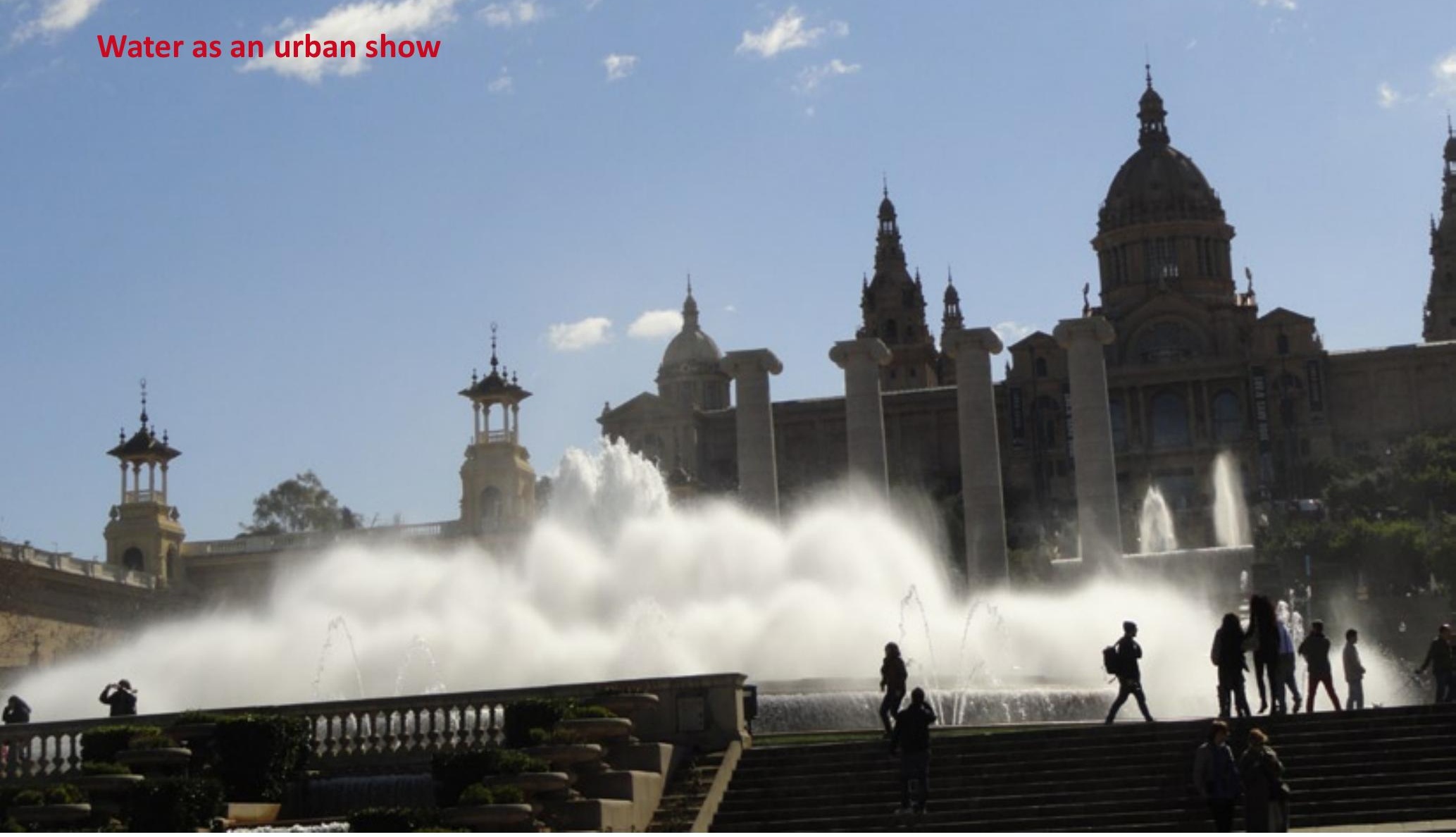

Barcelona. The magic fountain

A show of water, light, colour and sound
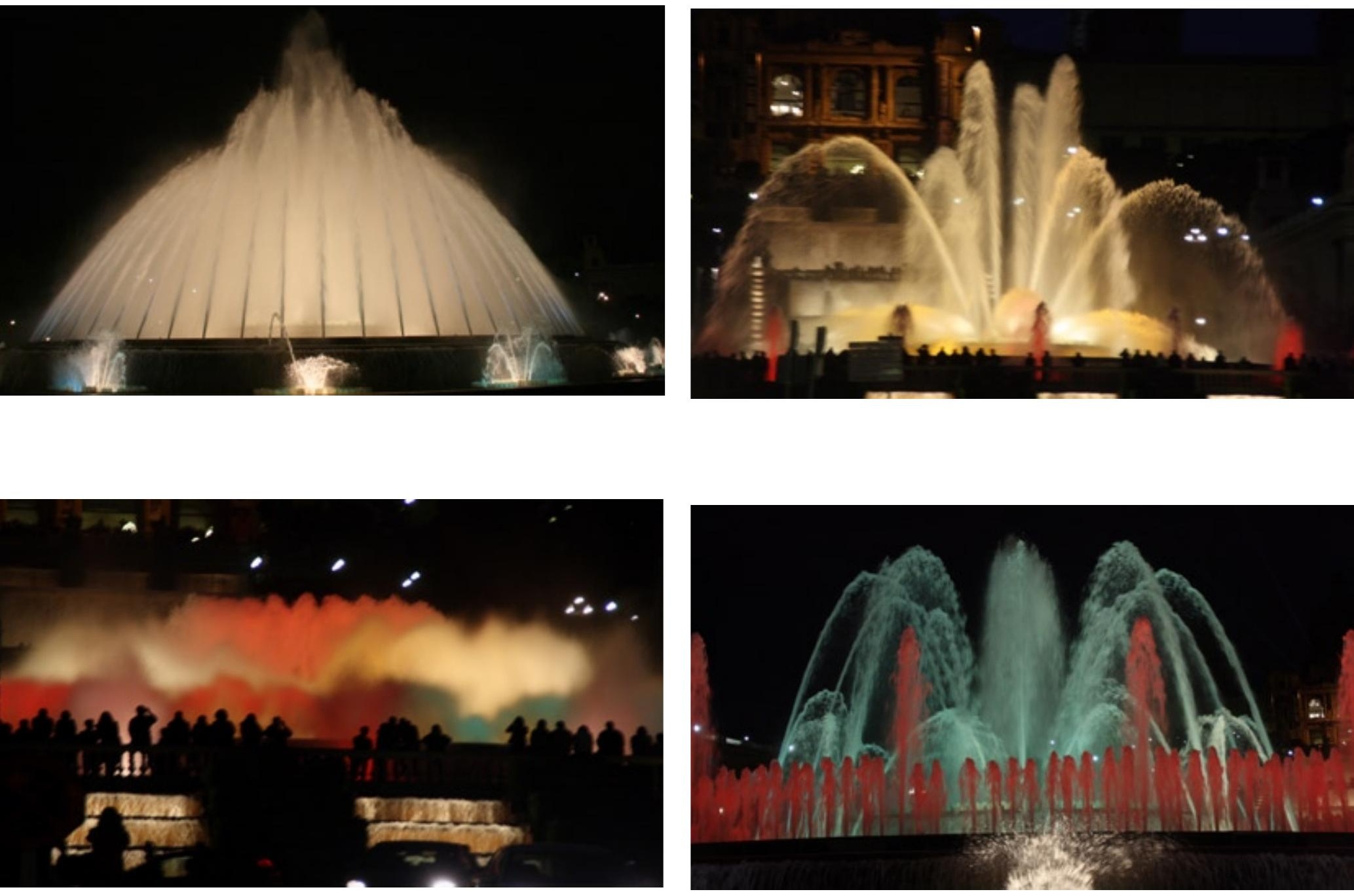


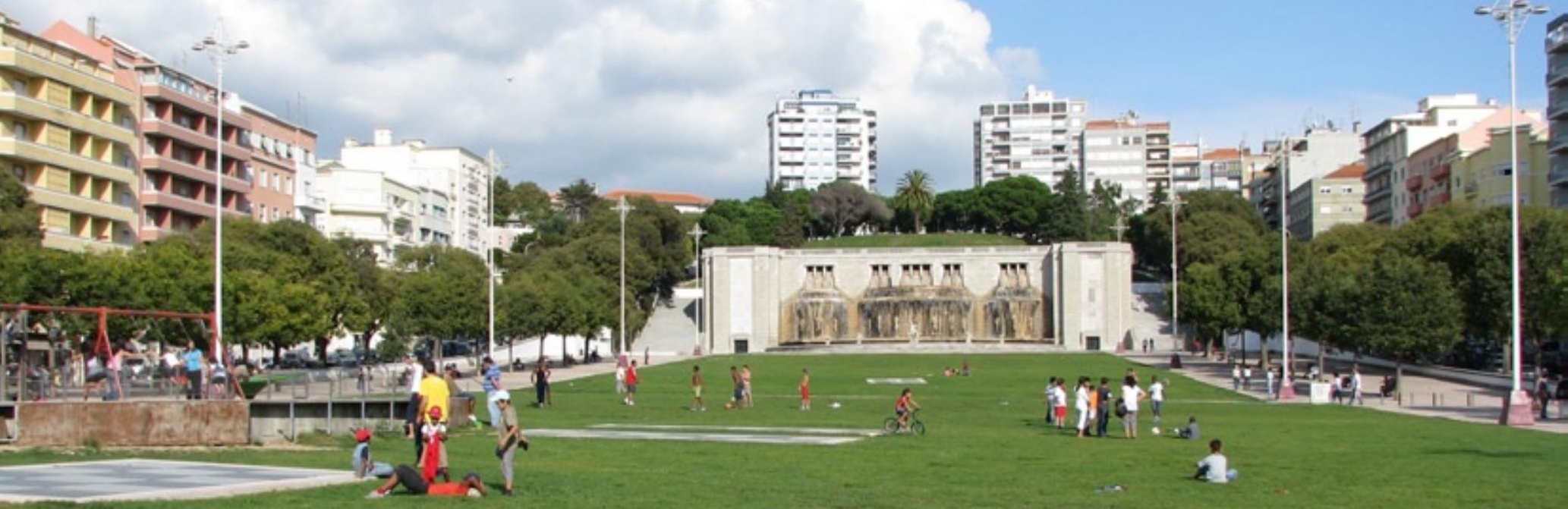

\section{Luminous Fountain}

Lisboa
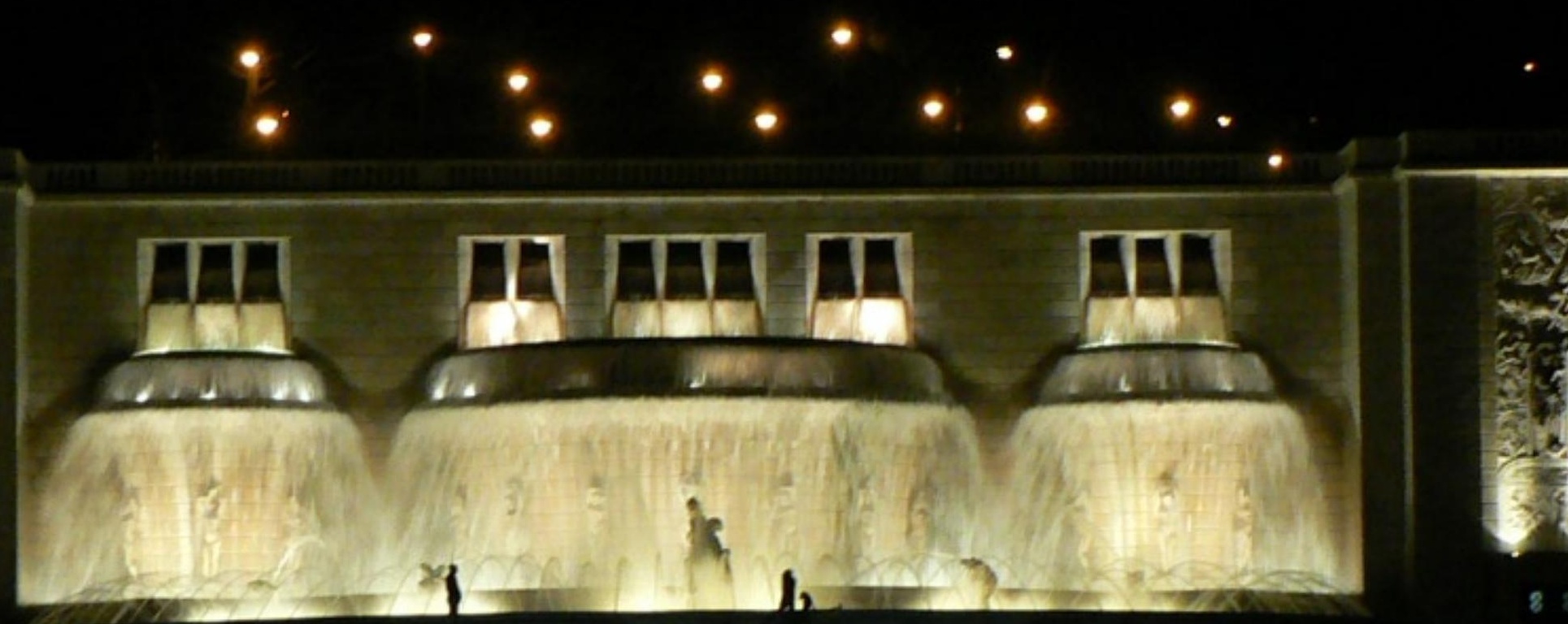


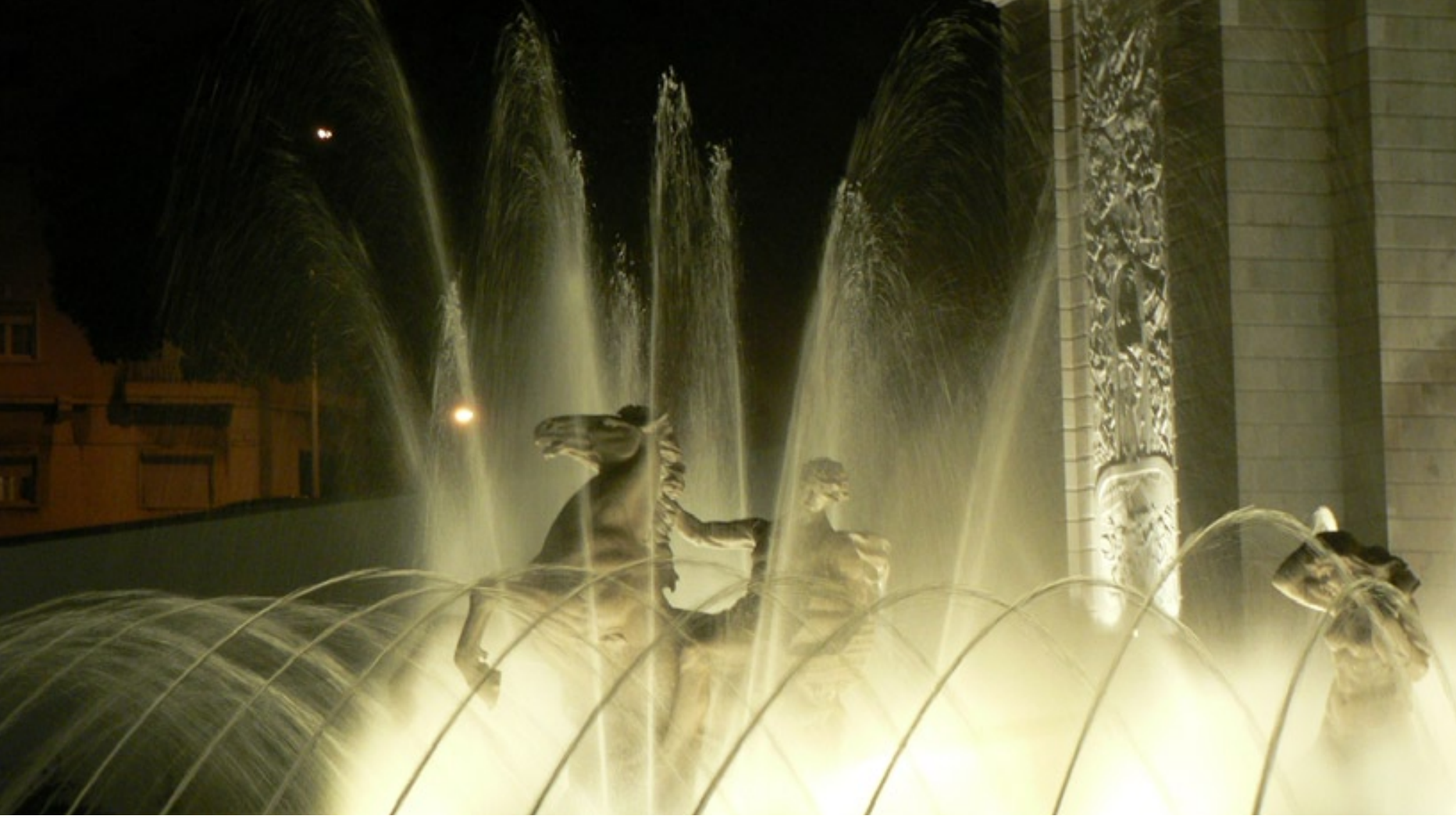

In 1940 the Salazar's regime celebrated two historic dates (1140 and 1640) considered representative of the Nation. The dates correspond to the formation of the kingdom of Portugal and to the proclamation of Portuguese independence against the kingdom of Castile.

In 1938, the dictator Salazar disclose the program of the celebrations and appealed to public services to show commitment to the preparation of the event, demonstrating that Portugal has a "great capacity to achieve".

The construction of a monumental fountain was one of the initiatives practiced by public services in response to the call from Salazar. The proposal, presented formally in 1938 by the Waters Supervisory Committee of Lisbon, belonging to the Ministry of Public Works and Communications, then headed by Duarte Pacheco.

The project counted two sets of sculptures and two ceramic panels, complementing the architectural structure of the monument. There were also considered programs based on effects of water and light as an element that values the work. The territory of Alameda D. Afonso Henriques was chosen for the deployment of the monument.

However, the construction of the work, estimated at 480 days, dragged on for ten years (1938-1948). During this period, development work was reported with enthusiasm by the press, through articles in newspapers and magazines, propaganda disseminated by Salazar (Elias2010)

The fountain was built to celebrate the regular water supply to the eastern part of the city. The project is by the brothers Carlos Rebello de Andrade and Guilherme Rebello de Andrade and is framed in the conservative style, often called Soft Portuguese (Fernandes 2003), dominant in the 1940s; the sculptures are by Maximiano Alves (Cariátides), Diogo de Macedo (Tejo y Tágides); the bas-reliefs (side panels) by Jorge Barradas.. 


\section{To conclude}

Regardless of political regimes and historical moments, the provision of water to the city is part of public policies and rulers, whether dictators or not, watch, in some way, to make them effective. Therefore, the manifestation of their benevolence will result in a development of the fountains linked to the increase in public ornamentation. The marble sculpture will play an important role in the manifestation of the prince's power.

Within the walled city the fountains will be organized in three main types. The first is that of watertowers, due to hydraulic problems, usually attached to the wall as a second sculpted skin and that may have a monumental artistic manifestation or be limited to more cautious style of the "fountains in architecture". The second type will be that of the isolated fountains of a relatively modest scale since the urban space they use is relatively small. This second type can opt for obelisks, canopy fountains, mainly with a stonework. The third type is that of the fountains with sculpture, usually on a pedestal, in which the mechanisms and pipes of the fountain are hidden and separating the water spouts from the sculpture. Depending on the space these fonts grow in size and ornament.

Throughout the nineteenth century an important part of these fountains will be replaced by cast iron fountains, monumental or not. Given the cost of the marble or bronze of the statues, we see the emergence of sculptural fountains, first in lead, until the Fonte d'Art industry is able to make models that compete in quality with those of bronze. An industry associated to the new urban planners and designers, that will export a model of "city making" worldwide. At this same time, the model of hygienist thought will develop public parks, as "lungs of the city", and, in them, water will take another form: canals, rivers, ponds, lakes, shallow waters. The new types of public space will also determine an evolution in the form of the fountains, which will gain in monumentality and introduce the waterfall into the new urban parks. Finally, end of XIX century early XX Century, the introduction of electricity will turn the sources into a spectacle of water, light, colour and even sound.

As we have seen throughout the article, water in the city will abandon its mission related to the maintenance of everyday life or work (an aspect that would require another approach that we have not addressed), to become one of the principal elements of public and urban ornamentation, contributing to urban decorum policies of cities that transit from congestion within the wall enclosure, to their expansion beyond their boundaries, to metropolitan growth managed by a new ruling class, - an patrician urban class linked to the interests of service companies [water, electricity, gas, transport]- which in the context of the incipient formal democracy makes good the Enlightenment topic, "Everything for the people, but without the people". In spite of this, the interventions carried out will shape the morphology of the city and today form most of these new urban spaces and their water features can be considered quality public spaces in our cities. 


\section{References}

ADAMS, William H. (1991). Roberto Burle Marx. The Unnatural Art of Garden. MOMA.

ÁGUAS, Sofia. (2009). Design de candeeiros de iluminaçâo pública para a sustentabilidades do Espaço Público [Doctoral, Universitat de Barcelona]. http://hdl.handle.net/10803/1546

ÁGUAS, Sofia. (2013). Fim da Escurdiâo. Os candeeiros de lluminaçâo Pública de Lisboa: 1780-1928. Rossio. Estudos de Lisboa, 2, 90-105. http://www.cm-lisboa.pt/publicacoes-digitais/por-tematica?pub=770

ALBARDONEDO, Antonio J. (2002). El urbanismo de Sevilla durante el reinado de Felipe II. Guadalquivir Ediciones. ALBERTI, Leon Battista. (1452). De Re Aedificatoria (1452) (Spanish Edition in charge of Javier Fresnillo from tje 1550 Edition in FLorencia). Akal.

ALPHAND, Adolphe. (s. f.). 1867-1873 Les Promenades de Paris (Institut National d'Histoire de l'Art). J.Rothschild editeur. http://gallica.bnf.fr/ark:/12148/bpt6k6276852z/f4.image.r=Alphand

ALPHAND, Adolphe. (1867). 1867-1873 Les promenades de Paris / histoire, description des embellissements, dépenses de création et d'entretien des Bois de Boulogne et de Vincennes, Champs- Elysées, parcs, squares, boulevards, places plantées, études sur l'art des jardins et arboretum (Institut National d'Histoire de l'Art). J.Rothschild editeur. http:// gallica.bnf.fr/ark:/12148/bpt6k6276852z/f4.image.r=Alphand

ALPHAND, Alphonse; ERNOUFF, Baron de. (1875). L'art des jardins: Parcs, jardins, promenades: Étude historique, principes de la composition des jardins, plantations, décoration pittoresque et artistique des parcs et jardins publics: Traité pratique et didactique. J.Rotschild, ed. http://gallica.bnf.fr/ark:/12148

ANDRADE MARQUES, Inês Maria. (2012). Arte e habitação em Lisboa 1945-1965. Cruzamentos entre desenho urbano, arquitetura e arte pública [Universitat de Barcelona]. http://tdx.cat/handle/10803/145901

ARANTES, Otilia. (2002). Uma estratégia fatal A cultura nas novas gestões urbanas. En Arantes, O- Vainer, C-Maricato, E. A cidade do pensamento único. Desmanchando consensos. Editora Vozes.

ARRANZ, Manuel, GRAU, Ramon, \& LÓPEZ, Marina. (1984). El Parc de la Ciutadella. Una visió històrica. L’Avenç.

ASHWELL; A.M., \& O'LEARY, J. (1999). Cholula. La ciudad sagrada. Volkswagen de México.

ASSASSIN, Sylvie. (1990). L’Exposition Ibéro-Américaine de Séville. En AA.VV. Jean Claude Nicolas Forestier 1861-1930. Du Jardin au paysage urbain (pp. 111-120). Picard Editeur.

BECK, Ulrich. (1998). ¿Quées la globalización? Falacias del globalismo, respuestas a la globalización. Paidos.

BENÉVOLO, Leonardo. (1975). Diseño de la Ciudad (Edición castellana 1977). Gustavo Gili.

BERJMAN,Sonia. (1990). En la Ciudad de Buenos Aires. En AA.VV. Jean Claude Nicolas Forestier 1861-1930. Du Jardin au paysage urbain (pp. 207-219). Picard Editeur.

BERJMAN,Sonia. (1998). Parques y Plazas de Buenos Aires. La obra de los paisajistas franceses. Fondo de Cultura Económica.

BIGOTTE, João. (1999). Nossa Lisboa dos Outros. CTT Correios

BOHIGAS, O- PUIGDOMENECH,A- ACEBILLO, J- GALOFRÉ, J. (1983). Plans i Projectes per a Barcelona 1981/1982.

Ajuntament de Barcelona. http://cbab.bcn.cat/uhtbin/cgisirsi/0/x/0/57/28/686/X?user_id=INTERCAT

BOHIGAS, Oriol. (1963). Barcelona, entre el Pla Cerdà i el Barraquisme. Edicions 62.

BOHIGAS, Oriol. (1985). Reconstrucció de Barcelona. Edicions 62.

BOHL, Ch.C- LEJEUNE, J-F (ed). (2009). Sitte, Hegemann and the Metropolis:

Modern Civic Art and International Exchanges. Routledge. http://books.google.es/

BONNIER, Louis. (1917). Pourquoi nous ouvrons une Ecole d'Art Public? L'Art public. Publication de l'Ecole supérieure d'art public, 1. gallica.bnf.fr

BORJA, Jordi. (2009). Luces y sombras del urbanismo de Barcelona. Universitat Oberta de Catalunya.

BORJA, Jordi (ed). (1995). Barcelona: Un modelo de transformación urbana. Progr ama de gestión Urbana (PGU-LAC), BOYER, Christine. (1994). The City of Collective Memory. MIT Press.

BROERMAN, Eugéne. (1898). Oeuvre de l'Art Public. Premier Congrés International. Bruxellles, 1898. Auguste Benard. http://gallica.bnf.fr/

BUIGAS, Carlos. (1978). La Fuente. Ed. Marte.

BURNHAM, Daniel H \& BENNETT, Edward, H. (2009). Plan of Chicago (1909). The Great Books Foundation.

CAETANO, Joaquim, \& CRUZ, Jorge. (1991). Chafarizes de Lisboa. [S.I.] : Distri ed.

CAILLAUT, Pierre-Yves. (2008). La place royale de Nancy. En Figueria de Faria, M (Coord) Praças reais. Passado, presente, futuro (pp. 343-346). Livros Horizonte.

Proyecto de ley relativo á la construcción, por el Ayuntamiento de Barcelona, de un paseo marítimo en aquellá capital., (1918) (testimony of Cambó, Francesc). boe.es

CAMBÓ, Francesc (1918) Proyecto de paseo marítimo que formule el Ayuntamiento de Barcelona, boe.es

CAPEL, Horacio. (2005). El Modelo Barcelona: Un exámen crítico. Ediciones del Serbal.

CASALAS COSTA, Vicente. (2009, enero 8). Barcelona, Lisboa y Forestier: Del Parque Urbano a la Ciudad Parque. Scripta Nova. Revista electrónica de geografía y ciencias sociales, XIII(296(1)). http://www.ub.edu/geocrit/sn/sn-296/sn-296-2. htm 
CASTELLS, Manuel; BORJA, Jordi. (1999). Local y global:la gestiónde las ciudades en la era de la información (United Nations for Human Settlements (Habitat) ,). Taurus.

CASTRO MELLADO, J.L. (2017). El diseño del Espacio Público como estrategia de recuperación de los polígonos de vivienda masiva. Los casos de Montbau y Ciutat Meridiana (Barcelona) [Master]. Universitat de Barcelona.

CERDÀ, Ildefons. (1859). Teoría de la Construcción de las ciudades aplicada al proyecto de reforma y Ensanche de Barcelona. En In Busquets, Joan (Coord). Teoría de la construcción de las ciudades. Cerdà/ Barcelona. MAP- Ajuntament de Barcelona.

CERDÀ, Ildefons. (1867). Teoría General de la Urbanización y aplicación de sus principios y doctrinas a la reforma y ensanche de Bacelona. Imprenta Española. http://www.anycerda.org/web/es/arxiu-cerda/fitxa/teoria-general-de-laurbanizacion/115

CHOAY, Françoise. (1998). Art Urbain. En MERLIN, Pierre-CHOAY, Françoise.Dictionnaire de I'Urbanisme et de

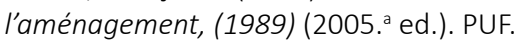

CIVIS. (1918). El Paseo Marítimo de Barcelona. CIVITAS, 2(16), 12-17.

COMISIÓN DE ESTETICA EDILICIA. (1925). Proyecto Orgánico para la Urbanización del Municipio. El Plano Reguladory de Reforma de la Capital federal. Talleres Peuser.

COSTA, João Pedro. (2007). La ribera entre proyectos. Formación y Transformación del Territorio Portuario, a Partir Del Caso De Lisboa [Universitat Politècnica de Catalunya]. http://tdx.cat/handle/10803/6960

CUNHA, Joana. (2005). Arquitectura Privada, Política e Factos Urbanos em Lisboa: Da cidade pombalina à cidade liberal. Universidade Nova de Lisboa.

DAVIS, Mike. (1990). City of Quartz. Excavating the Future in Los Angeles. Verso.

DUVERGER, Heriberto. (1990). El maestro francés del urbanismo criollo para la Habana. En AA.VV. Jean Claude Nicolas Forestier 1861-1930. Du Jardin au paysage urbain (pp. 207-219). Picard Editeur.

ELIAS, Helena. (2007). Arte Pública e Instituições do Estado Novo. Arte Pública das Administrações Central e Local do Estado Novo em Lisboa: Sistemas de encomenda da CML e do MOPC/MOP (1938-1960). [Universitat de Barcelona]. http://tdx.cat/handle/10803/96401

ELIAS, Helena. (2010). Building the Monumental Source Alameda Afonso Henriques (1938-1948) through journals and administrative process. On the W@terfront. Public Art.Urban Design.Civic Participation.Urban Regeneration, 15, 3-34. http://revistes.ub.edu/index.php/waterfront/article/view/18876

ENGELS, Friederic. (1845). La situación de la clase obrera en Inglaterra. Departament d'Història Moderna i

Contemporània - Universitat Autònoma de Barcelona. www.marxists.org/catala/obres.htm

FABRE, Jaume (2017). The Four Strips. in Barcelona Public Art Museum. www.bcn.cat/artpublic

FAVA, Nadia. (2004a). Progetti e processi in conflitto: /l fronte marittimo di Barcellona [Politècnica de Catalunya]. http:// hdl.handle.net/10803/6796

FERNANDES, J.M. (2003). Português Suave: Arquiteturas do Estado Novo. IPPAR.

FIOL COSTA, Carme. (2008). Retícules i diagonals el Pla Jaussely de Barcelona i el Pla Burnham de Chicago. Universitat Politècnica de Catalunya. http://www.tdx.cat/handle/10803/6964

FORESTIER, J.C.N. (1906). Grandes villes et systemes de Parcs (1997. Leclerc, Bénédicte; Tarragó i Cid, Salvador). Norma.

FORESTIER, J.C.N. (1924). Mémoire de monsieur J. C. N. Forestier sur l' avenue côtière. En Grandes Villes et systèmes de Parcs (1997. ${ }^{a}$ ed., pp. 227-348). Éditions Norma.

FRAMPTON, Kenneth. (1983). Towards a Critical Regionalism: Six points of an architecture of resistance. En The AntiAesthetic. Edited by Hal Foster. Bay Press.

FRAMPTON, Kenneth. (1987). La Renovació de Barcelona: Una Apreciació. En In AA.VV. Barcelona Espais i Escultures (1982-1986). Ajuntament de Barcelona.

GARCIA, Maycel; RíOS, Marien. (2013). La Habana Vieja, un presente audaz / Old Havana, a fearless present fearless. On thew@terfront [en línia], 25, 36-56. http://www.raco.cat/index.php/Waterfront/article/view/263777

GATEPAC. (1932). El barrio chino de Barcelona. A.C. Documentos de Actividad Contemporánea, Año I/(6), 31-33.

GÓMEZ DÍAS, F. (2008). De Forestier a Sert. Ciudad y Arquitectura. La Habana 1925-1960. ABADA Editores.

GUIMARAES, Aline Sampaio de Mello. (2015). Burle Marx: Caminos del paisajismo moderno brasileño [Universitat Politècnica de Catalunya]. http://www.tdx.cat/handle/10803/323893

HADDAD, Marie. (2017a). The Eventrement of Paris and the configuration of the Alphand-Davioud-Hittorff Paradigm on urban design. On the w@terfront [en línia], 51, 25-49. http://raco.cat/index.php/Waterfront/article/view/320432

HADDAD, Marie. (2017b). Urban Hygiene Awareness in a suffocated Barcelona. On the w@terfront [en línia], 51, 7-24. http://raco.cat/index.php/Waterfront/article/view/320432

HALLAYS, A. (1920). Nancy. Herni Laurens. gallica.fr

HAMANN, Johanna. (2016). Leguía, el Centenario y sus monumentos. Lima 1919-1930. Pontificia Universidad Católica del Perú.

HAMANN, Johanna. (2011). Monumentos públicos y espacios urbanos. Lima, 1919-1930 [Universitat de Barcelona]. http://hdl.handle.net/10803/1552 
HARVEY, David. (1990). The Condition of Postmodernity. Blackwell.

HAUSSMANN, Georges Eugène. (1893). Mémoires du Baron Haussmann. Vol. III. Grands Travaux de Paris: Le plan de Paris-Les services d'ingénieurs-Voie publique-Promenades et plantations-Service des eaux-Architecture et beauxarts. Victor Havard, editeur. http://gallica.bnf.fr/

HEGEMANN, W; PEETS,E. (1922). The American Vitruvius: An Architects' Handbook of Civic Art (1988. a ed.). Princenton Academic Press. https://archive.org/details/americanvitruviu00hege/page/n6

HENRIQUES DA SILVa, Raquel. (1997). Lisboa Romântica, Urbanismo e Arquitectura, 1777- 1874 (vol I). Universidade Nova de Lisboa.

HERNÁNDEZ SÁNCHEZ, Adriana. (2009). Espacio público en el centro histórico de Puebla-México [Universitat de Barcelona]. http://hdl.handle.net/10803/1547

HERNÁNDEZ-CROS, J.E. (1982). Forestier a Barcelona. Quaderns d'Arquitectura i Urbanisme, 151, 27-39.

HINDI, Nadine. (2015). On the making of public spaces in Beirut [Universitat de Barcelona]. http://hdl.handle. net/10803/309135

HITCHCOCK, H-R- JOHNSON, Ph. (1922). The Inernational Style. W.W.Norton \& Company.

HOWARD, EBENEZER. (1898). To-morrow: A Peaceful Path to Real Reform. S. Sonnenschein \& Co., Ltd. http://www. sacred-texts.com/utopia/gcot/index.htm

HOWARD, Ebenezer. (1902). Garden Cities of Tomorrow. S. Sonnenschein \& Co., Ltd. http://www.sacred-texts.com/ utopia/gcot/index.htm

JACOBS, Jane. (1961). The Death and Life of great american cities. Random House.

JAUSSELY, Leon. (1907). Proyecto de enlaces de la zona de Ensanche de Barcelona y de los pueblos agregados. http:// www.etsav.upc.es/personals/monclus/cursos/enlaces.htm

KOSTOF, Spiro. (1992). The City Assembled. The Elements of Urban Form Through History (Revisions by Greg Castillo). Thames \& Hudson.

KOSTOF, Spiro. (1995). A History of Architecture (Revisions by Greg Castillo). Oxford University Press.

KUBLER, George. (1967). La traza colonial de Cholula. Estudios de Historia NovoHispania, 2, 1-30.

LADD, Brian K. (1987). Urban aesthetics and the discovery of the urban fabric in turn-of-the-century Germany. Planning Perspectives, Volume 2(Issue 3).

LASH, S- URRY, J. (1994). Economies of Signs \& Space. Sage.

LAUGIER, Marc-Antoine. (1755). Essai sur l'Architecture (segunda). Duchesne Librairie. http://www.archive.org/stream/ surlarchitecture00laug\#page/n1/mode/2up

LE CORBUSIER P. JEANNERET y Gatepac (G. E.). (1934). Barcelona. Esquemas para el proyecto conjunto. A.C. Documentos de Actividad Contemporánea, año IV(13), 21-23.

LEFEBVRE, Henry. (1973). La revolución urbana (1971). Alianza Editorial.

MARTIRE, Agustina. (2008a). La costanera sur de Buenos Aires-Borde y horizonte de la ciudad. On the w@terfront [en línia], 11, 65-72. http://raco.cat/index.php/Waterfront/article/view/218452

MATOS, María. (2016). Public space design for flooding: Facing the challenges presented by climate change adaptation [Tesis Doctoral, Universitat de Barcelona]. http://hdl.handle.net/10803/400001

MATOS, Maria; COSTA; João PEdro. (2016). Climate Change and Urbanism. A new role for public space design? En In REMESAR, A (ED) The Art of Urban Design in Urban Regeneration (pp. 62-85). Edicions de la Universitat de Barcelona. McNEILL, David. (1999). Urban Change and the European Left. Tales from the New Barcelona. Routledge.

MOISY, NORMAND et autres. (1855). Fontaines de Paris. Bance. http://catalogue.bnf.fr/ark:/12148/cb33490991z

MOLINA, F.D. (Arch). (1850). Monumento a Fernando II en la plaza Real (Exp. Aa 1136 3/1). AHCB.

MONCLÚS, Fco. Javier. (2005). El Modelo Barcelona, ¿Una fórmula Original? De la «Reconstrucción» a los Proyectos urbanos estratégicos (1997-2004). Perspectivas Urbanas, 3. http://www.raco.cat/index.php/Perspectivas/article/ view/84991 [Consulta: 09-01-17]

MONTANER, J.M.- ALVAREZ, F- MUXÍ, Z (ED). (2011). Archivo Crítico Modelo Barcelona, 1973 -2004. Ajuntament de Barcelona.

MONTERo, Marta Iris. (1997). Burle Marx. The Lyrical Landscape. Thames \& Hudson.

MONTOLIU, Cebrià. (2000, 2001). (1913) Las modernas ciudades y sus problemas á la luz de la Exposición de Construcción Cívica de Berlín. Ciudades: Revista del Instituto Universitario de Urbanística de la Universidad de Valladolid, La Ciudad Jardín cien años después / coord. por ROGER-HENRI GUERRAND, MARÍA A. CASTRILLO ROMÓN(6), 187-204. https://dialnet.unirioja.es/servlet/revista?codigo=2694

MORAL RUíz, Camen del. (2013). El Retiro de Madrid en sus planos: De jardín real a parque público. http://www. fronterad.com/?q=retiro-madrid-en-sus-planos-jardin-real-a-parque-publico

MUÑOZ, Francesc. (2008). Urbanalización. Paisajes comunes, lugares globales. Gustavo Gili.

OCHOA, Ana Rita. (2011). Cidade e frente de água. Papel articulador do espaço público [Universitat de Barcelona]. http://hdl.handle.net/10803/52893 
OLSEN, Donal J. (1986). The City as a Work of Art. London-Paris-Viena. Yale University Press.

PARQUE FUNDIDORA. (s. f.). Parque Fundidora [Http://www. parquefundidora.org/]. Parque Fundidora.

PESSOA, Fernando. (1997). Lisboa:What the tourist should see / O que o turista deve ver (1925). Livros Horizonte.

PI I ARIMON, Avel.li. (1854). Barcelona antigua y moderna o, Descripción é historia de esta ciudad desde su fundación hasta nuestros días: Contiene la topografía de Barcelona; su clima; calles y plazas; monumentos antiguos y modernos; palacios y edificios reales, nacionales, religiosos, civiles, públicos y particulares; gobierno y legislación antiguos y modernos; instituciones religiosas, cientificas, literarias, artísticas y filantrópicas; estados eclesiástico, judicial, civil y militar; hombres ilustres; estadística; bibliografia; marina, comercio, industria, descubrimientos, inventos; historia política desde la época de los Cartagineses hasta el año 1843; servicios, méritos, privilegios, etc. Etc.: Vols. I y II. Llibrería Polítécnica de Tomas Gorchs.

PINON, Pierre. (1991). Les Préfets Parisiens et l'Urbanisme. Chabrol et Rambuteau. Quelques percées avant le second empire. En CARS, Jean des et PINON, Pierre (ed) Paris. Haussmann. (pp. 21-33). Editions du Pavillon de I'Arsenal- Picard Editeur.

POËTE, Marcel. (1929). Introduction a l'Urbanisme (2000. a ed.). Sens\&Tonka.

PORCEL, Ezequiel; LLOPART, Amadeo; RUBIÓ, Nicolás. (1927). El urbanismo en las poblaciones modernas (II). Algunas consideraciones sobre las realidades de nustro urbanismo. La Construcción Moderna, XXV(17), 264-269.

REMESAR, A. (2004a). Do ferro fundido ao design urbano. En Brandão; P-Remesar, A (Ed). Design Urbano Inclusivo. Uma experiéncia de projecto em Marvila. (pp. 23-36). Centro Português de Design.

REMESAR, A. (2004b, julio). Historia de dos ciudades. Geoinnova, 10.

REMESAR, A (2007). O «estilo Alphand-Davioud- Hittorf» de mobiliário urbano nos centros históricos. Arquitecturas. $O$ jornal de negócios do mercado das cidades, 28, VIII-IX. https://ub.academia.edu/AntoniRemesar/Papers

REMESAR, A (2011). O carácter simbólico da rua, identidade e apropiação. En in BRANDÃO, P (ED) A rua é nossa... De todos nós ! Lisboa. MUDE- Instituto Superior Técnico.

REMESAR, A. (2013). Barcelona: Un modelo de Arte Público y Diseño Urbano. En In HAMANN, Johana (ED) LIma: espacio público, arte y ciudad (pp. 13-54). Pontificia Universidad Católica del Perú.

REMESAR, A. (2016). New Urban Decorum? Aesthetics To and Fro. En In Gralińska-Toborek;A -Kazimierska-Jerzyk, W (ED) Aesthetic Energy of the City (pp. 19-54). Wydawnictwo Uniwersytetu Łódzkiego (Łódź University Press).

REMESAR, A. (2017). Agua, espacio público, ¿Democracia? En In CORBELLA, D (Ed) L'aigua i l'espai públic. Anàlisi dels efectes del canvi climàtic. (pp. 77-112). Edicions de la Universitat de Barcelona.

REMESAR, A. (2019). Art and Participation. Edicions de la Universitat de Barcelona.

REMESAR, A- NUNES DA SILVA, F. (2010). Regeneraçao Urbana e Arte Pública. En ANDRADE, P (ED) Arte Pública e Cidadania. Novas leituras da cidade criativa (pp. 83-102). Caleidoscopio.

REMESAR, Antoni, \& NUNES DA SILVA, Fernando. (2019). Políticas Urbanas: Arte Pública na Regeneração Urbana. En ANDRADE, P; ALMEIDA MARQUES, C; CUNHA BARROS, José da (Ed) Arte Pública e Cidadania (2 (revista e aumentada), pp. 73-115). Editora Caleidoscópio- Edição e Artes Gráficas, SA. http://doi.org/10.30618/978-989-658-589-1

REMESAR, A, DE LECEA, I., \& GRANDAS, M. C. (2010). La fuente de las tres gracias en Barcelona. http://www.raco.cat/ index.php/Waterfront/article/view/214756

REMESAR, A; POL, E. (1999). Repensar el río. Taller de Participación ciudadana «Usos Sociales del río Besòs». Publicacions i Edicions de la Universitat de Barcelona.

REMESAR, A: SALAS, X; VIDAL, T. (2016). Urban Governance and Creative Participation in Public Space and Public Art. En In REMESAR, A (ED) The Art of Urban Design in Urban Regeneration (pp. 112-156). Edicions de la Universitat de Barcelona.

REMESAR, A, \& COSTA, J. P. (2010). Multifunctional land use in the renewal of harbour areas: Patterns of physical distribution of the urban functions. http://www.raco.cat/index.php/Waterfront/article/view/216970

RIONET, Florence. (1996). L'atelier de moulage du musée du Louvre[Texte imprimé]: 1794-1928. Réunion des musées nationaux.

RÍOS DÍAZ, Marien. (2017). ¿Hacer Ciudad? Barcelona, la construcción del paisaje, 1929 -1973 [Doctoral, Universitat de Barcelona]. http://hdl.handle.net/10803/481954

ROBINSON, Ch. Mulford. (1904). Modern Civic Art or The City Made Beautiful. G.P. Putnam's Sons. http://www.archive. org/details/civicartormodernOOrobirich

ROCA, Francesc. (1971). Cebrià Montoliu y la «ciència cívica». Cuadernos de arquitectura y urbanismo [en línia], 80, 41 46. http://www.raco.cat/index.php/CuadernosArquitecturaUrbanismo/article/view/111033/169920

ROSENZWEIG, Roy; BLACKMAR, Elizabeth. (1992). The Park and the People: A History of Central Park (1992. ${ }^{\text {e ed.). }}$ Cornell University Press. https://www.amazon.com/exec/obidos/ASIN/0801497515/centralpark-20

ROURA, J.M. (1970). Carlos Buigas. Mago y poeta del agua-luz. Ediciones Unidas.

ROVIRA I TRIAS, Antonio. (1876). Proyecto de una fuente de hierro monumental destinada al actual suritdor de la plaza real. Arxiu Administrariu de Barcelona.

ROVIRA Y RABASSA, Antonio. (1899). El hierro: Sus cortes y enlaces. Librería de Ribó y Martín. http://www.dmg-lib.org/ 
$\mathrm{dmglib} / \mathrm{main} /$ portal.jsp?mainNaviState=browsen.docum. meta\&id=13176009

RUBIÓ I TUDURÍ , N,M,. (1928, junio). Els jardins de J.C. N. Forestier a tot el món. D’ací i d'allà, XVII(126), 210-211.

SABATÉ, Joaquim. (1999). El proyecto de la calle sin nombre. Los reglamentos urbanos de la edificación París-Barcelona. Fundación Caja de Arquitectos.

SALAS, Xavier. (2015). L'artista com a facilitador en els processos de participació ciutadana: El cas Baró de Viver a Barcelona [Tesis Doctoral, Universitat de Barcelona.]. http://hdl.handle.net/10803/308505

SARMANT, Th. (1999). La Ville de París. Modèle de la figure centrale de la fonatine de la rue Grenelle [Web]. Carnavalet. Histoire de Paris. http://www.carnavalet.paris.fr/fr/collections/la-ville-de-paris-modele-de-la-figure-centrale-de-lafontaine-de-la-rue-de-grenelle

SERT, Josep Lluís. (1942). Can our Cities Survive? (Generalitat de Catalunya, 1999 (trad. Catalan)).

SIMÓ SOLSONA, M. (2016). Evaluating the policies of urban regeneration in Europe. En Remesar, A (Ed) The Art of Urban Regeneration. Policies, Public Space and Governance. Publicacions de la Universitat de Barcelona.

SIQUEIRA, Vera Beatriz. (2001). Burle Marx. Cosac \& Naify, Ed.

SOJA, Walter. (1989). Postmodern Geographies: The Reassertion of Space in Critical Social Theory. Verso.

SORKIN, Michael (Ed). (1992). Variations on a theme park. The New American City and the End of Public Space. Hill and Wang/Farrar, Straus and Giroux.

SYNDICAT D'INITIATIVES. (1931). Nancy et ses environs. Imprimerie Camille André et cie. gallica.fr

TATJER, J. (1998). L'enginy de Carles Buigas (1899- 1979). Agbar- Ajuntament de Barcelona.

TORRES I CAPELL, Manuel, Josep LLOBET I BACH, \& Jaume PUIG I CASTELLS. (1985). Inicis de la Urbanistica Municipal. Ajuntament de Barcelona. http://cbab.bcn.cat/uhtbin/cgisirsi/0/x/0/57/28/686/X?user_id=INTERCAT

TZONIS, Alexander. (1977). Hacia un entorno no opresivo (Towards a Non-opressive Environment). Hermann Blume. UGRAMIN, Luigi. (s/f). Villa Comunale. Comune di Napoli. http://www.comune.napoli.it/flex/cm/pages/ServeBLOB. php/L/IT/IDPagina/22431

UNWIN, Raymon. (1917a). El arte de la urbanización (I). CIVITAS, 2(12), 142-145.

UNWIN, Raymon. (1917b). El arte de la urbanización (II). CIVITAS, 2(13), 165-171.

URRY, John. (1995). Consuming Places. Routledge.

VALENTE PEREIRA, Cristóvão. (2013). Três Chafarizes de Lisboa. Rossio Estudos de Lisboa, 2, 118-128. http://www.cmlisboa.pt/publicacoes-digitais/por-tematica?pub=770

ZUKIN, Sharon. (1998). Politics and aesthetics of public space: The "American» model. En Subirós, Pep (ed) Ciutat real, ciutat ideal. Significat i funció a l'espai urbà modern [Real city, ideal city. Signification and function in modern space],

(pp. 37-43). Centre de Cultura Contemporània.

\section{Acknowledgments}

This work has been possible with the support of the projects HAR2012-30874 PTDC / EC M-URB / 2162/2014 and HAR2017-88672-R financed by the Ministry of Science and Innovation of Spain; of project HAR2012-30874 PTDC / EC M-URB / 2162/2014, financed by the Foundation for Science and Technology of Portugal. It was carried out within the framework of the collaboration agreement between the City Council of Barcelona (Disctricte de Sant Andreu), the Bon Pastor Neighborhood Association and the POLIS Research Center of the University of Barcelona. 